Boletim Técnico da Divisão de Experimentação e Pesquisas I N S T I T U TO A G R O N ÔM I C O

Vol. 2 Campinas, Outubro de $1942 \quad$ N. 10

\title{
A "FRAÇÃO ARGILA" DOS SOLOS DO ESTADO DE SÃO PAULO E SEU ESTUDO ROENTGENOGRÁFICO $\left(^{*}\right)$
}

\author{
J. E. de Paiva Neto
}

\section{INTRODUÇÃO}

Desde os tempos mais remotos, o termo argila vem sendo empregado pelo homem para denominar, de modo geral, o barro plástico que serviu para seus trabalhos de cerâmica.

A cerâmica foi uma das artes mais perfeitas e seguida pelas velhas civilizações, tais como: a chinesa, a dos íncas, etc.

Posteriormente, o geólogo e o mineralogista se viram na obrigação e necessidade de classificar essa parte fina (argila) - produto de decomposição das rochas pelos agentes atmosféricos.

problema foi assim estudado e discutido, exclusivamente sob o ponto de vista do geólogo e mineralogista. Mais alem, foi necessária a intervenção do químico com sua ciência, pois a composição química desse material podia esclarecer alguns pontos desejados, até então obscuros. Nesta altura, a nossa argila (barro plástico) tinha sido admitida, química e mineralogicamente, como sendo um ou vários minerais que se enquadravam na série dos silicatos hidratados de alumínio. Para os estudos de até então, o problema estava relativamente resolvido.

Parou a questão nesse ponto, até que surgiu o célebre Lawe, com as suas pesquisas sobre a difração dos raios $\mathrm{X}$ e a grande possibilidade de serem pesquisadas as redes cristalinas dos minerais. Em continuação a estes estudos, seguiram os trabalhos de Bragg (16) e de seus colabora-

$\left(^{*}\right)$ Trabalho a ser apresentado no 2.0 Congresso Brasileiro de Química a realizar-se em Curitiba, de 26 a 31 de janeiro de 1943. 
dores, os quais proporcionaram ao mundo científico a faculdade de conhecer, por aquele método de difração, as redes cristalinas até dos silicatos mais complexos, tais como: as micas e outros. Isзo tudo foi de elevado valor para a identificação e classificação precisa dos vários minerais que entram na composição da "argila".

Viu-se, assim, que a composição desse material podia ser a mais variada imaginavel, tanto na percentagem como na espécie dos seus constituintes; estes podem ser, alem dos verdadeiros silicatos hidratados de alumínio, óxidos mais ou menos hidratados de alumínio, ferro, silício, etc.

Hoje, para o estudo mais generalizado da fração argila, devemos ainda entrar em combinação com as teorias e as concepcõ̃ $ə s$ modernas sobre o estado coloidal da matéria.

Somente baseado nesse notavel conjunto de pesquisas lísico-químicas, é que o pedólogo pode admitir e estabelecer uma nova concepção para a "fração arçila". Esta concep̧̧̃o tinha como base as aimensões dos diâmetros médios das partículas. Naturalmente, apareceram vários experimentadores, os quais opinavam diferentemente para estabelecer as dimensões desses diâmetros médios máximos das partículas, que ainda pudessem ser consideradas como possuidoras das principais propriedades caraterísticas do estado coloidal. As dimensões máximas consideradas pela ciência do solo estão compreendidas entre 1 e 10 microns. Em nossa análise mecânica, a fração argila tem, como diâmetro médio máximo, dois microns. Na escala de Schone, a fração argila é aquela que possue os diâmetros médios máximos de 10 microns; na escala de "Bureau of soil" dos Estados Unidos da América do Norte, essa dimensão máxima é de cinco microns; na de Kopecky, de 10 e, na de Atterberg, usada por nós, é de dois, como já dissemos.

Para maiores esclarecimentos sobre dimensões de partículas e agregados no mundo dos colóides, aconselhamos consultar $(1,2,3$, 4 e 5).

Segundo essa concepção, a matéria em alto grau de dispersão apresenta um elevado número de propriedades comuns. Em nossos estudos consideramos não somente a percentagem dessa fração (partículas menores do que dois microns), mas tambem a estrutura e composição químicas dos seus vários constituintes.

O quadro a seguir nos dá idéia dos tipos de micelas ou partículas mais comuns encontradas nos solos em geral. Parte desse quadro toi. obtida do trabalho de Hauser (6). 


\section{Grupo}

Tipo de rede cristalina

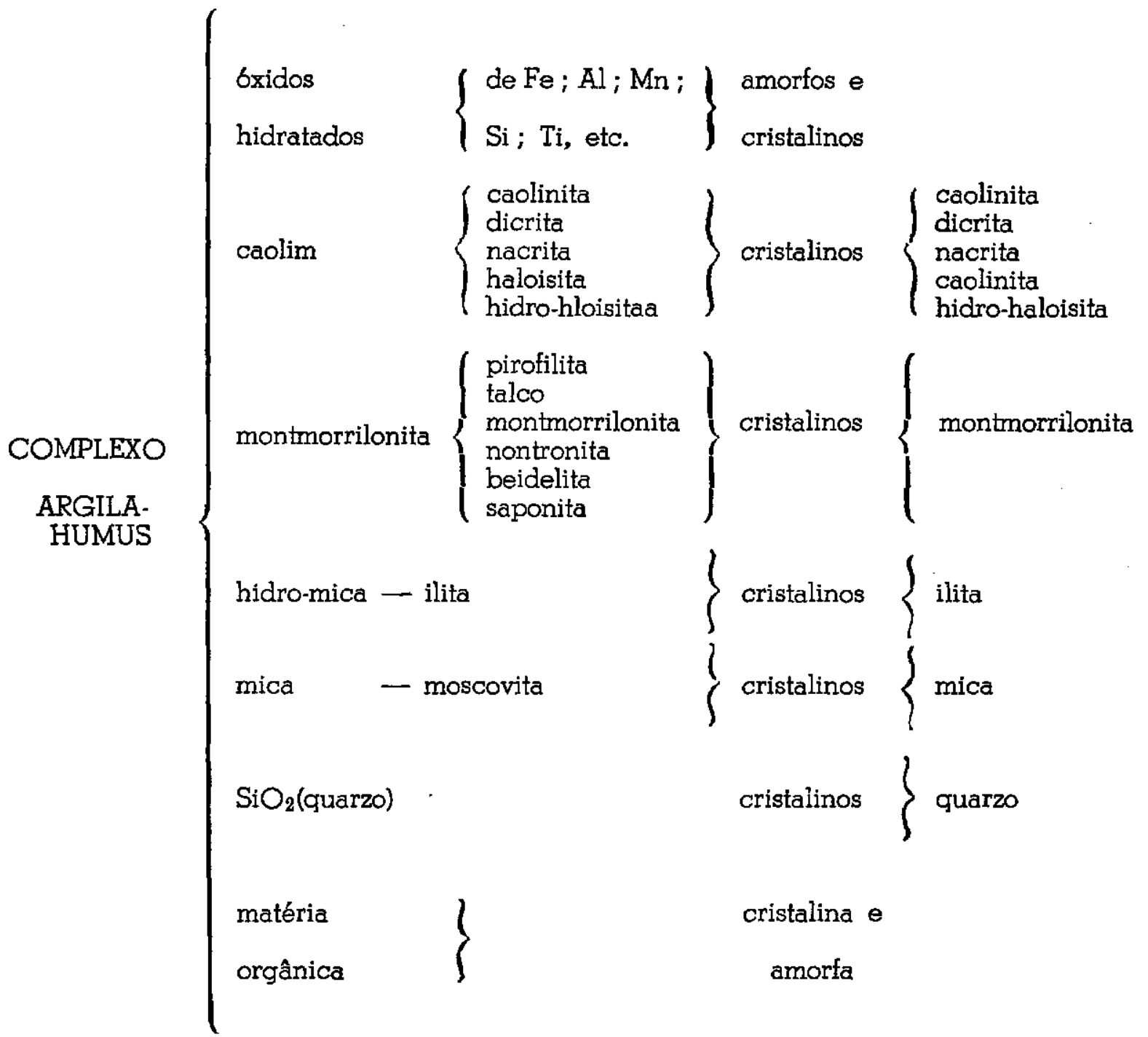

Assim, todos os fenômenos físicos e químicos originados no complexo argila só podem ser estudados e esclarecidos pela integração dos três fatores seguintes: $1 .^{\circ}$, o estado de dispersão da matéria ; $2 .^{\circ}$, a composição química e $3 .^{\circ}$, a estrutura física da rede espacial.

É no mundo dos menores do que dois microns que a superfície específica se vai mostrando cada vez mais ativa e possante.

Essa mesma atividade está tambem em estreita correlação com a estrutura física e química da micela.

A impermeabilidade, a plasticidade e a coesão do solo; a absorção dos iônios pelas radicelas das plantas; o equilíbrio dágua no solo; a retenção de catiônios; a maior ou menor contração do solo; a maior ou menor comprensibilidade; todos esses fenômenos estão estreitamente relacionados com os três fatores acima citados, ou seja, o grau 
de dispersão da matéria, a estrutura física e a estrutura química. Do exposto se depreende que, para o estudo do solo sob o ponto de vista agro-geológico é tambem básica a questão da "fração argila".

Com o intuito de contribuir para a consecução desse objetivo, vamos expor as seguintes preliminares. Nesse estudo não nos vamos perder em pormenores sobre divisões e sub-divisões de tipos de solo; tão somente traçaremos considerações sobre os grandes tipos, a saber: os Massapés e Salmourões, provenientes da formação geológica arqueana; - Glacial, que pode variar do argiloso do arenoso ; o Corumbataí, sobre a formação do mesmo nome e que, em geral, é argiloso; o Botucatú (Lava), terra roxa legítima e os arenosos procedentes do arenito sobre a mesma formação; o Baurú inferior e superior sobre o arenito Cretáceo Baurú. O material escolhido para a execução deste trabalho proveio de uma série de 500 perfís de solo e mais de 1000 amostras superficiais, tomadas em todo o Estado de São Paulo. Deu-se sempre preferência a amostras, as mais típicas possíveis.

Vamos iniciar pela análise mecânica, descrevendo, em primeiro lugar, os métodos empregados para peptizar e dispersar o material e, após estes, discorrer rapidamente sobre o método de análise mecânica natural, finalizando com o método de dosagem das diversas frações da análise mecânica empregado na Secção de Agro-geologia. Isso posto, daremos um gráfico mostrando a percentagem média dessas frações nos solos situados nas diferentes formações geológicas já citadas.

\section{ANÁLISE MECÂNICA TOTAL. \\ (Separação da "fração argila" total)}

Para proceder à análise mecânica dos vários tipos de solo de nosso Estado, não nos foi possivel empregar um método único, o que, todavia, tem sua lógica, porquanto, a origem e a composição desses diferentes tipos são as mai's diversas imaginaveis. Considerando esse fato, vimonos na contingência de elaborar três métodos, os quais daremos a seguir :

\section{Método de análise para terras essencialmente arenosas :}

20 gramas de terra seca ao ar são colocadas em um copo de Boêmia de 600 cc contendo $100 \mathrm{cc}$ de solução a $4 \%$ de carbonato de amônio. Leva-se para o banho de areia, onde, de vez em quando, se agita. A terra é triturada contra as paredes do copo, por meio de um bastão de vidro munido de borracha em uma das extremidades. 
Deixa-se no banho de areia até não exalar mais cheiro de $\mathrm{NH}_{3}$ e até que todos os conglomerados de argila se tenham desfeito. Isso facilmente se observa quando a terra é triturada com o bastão contra as paredes do vaso, pois não apresenta mais riscos de argila procedentes do destorroamento dos conglomerados.

Nesta altura, são adicionados $5 \mathrm{ME}$ de $\mathrm{NaOH}$, permanecendo, então, no banho de areia até expulsar completamente $\circ \mathrm{NH}_{3}$ deslocado pelo $\mathrm{Na}+$. Isto posto, faz-se passar a suspensão assim obtida por uma peneira de 0,2 mm, e, com a ajuda do bastão e água destilada, consegue-se facilmente a separação. Sobre a peneira ficam partículas maiores do que $0,2 \mathrm{~mm}$ até $2 \mathrm{~mm}$ (fração areia grossa), passando somente as menores do que $0,2 \mathrm{~mm}$.

Transfere-se para uma proveta de 500 cc, cujo volume é completado com água destilada e agita-se. Após 4 horas de repouso, retira-se com o auxílio de uma pipeta, a $5 \mathrm{~cm}$ abaixo do nivel da suspensão, 10 cc da mesma, que são colocados em uma cápsula tarada, pronta para seguir para a estufa a $110^{\circ} \mathrm{C}$. Esta é pesada até obter constância de peso, procurando-se, então, encontrar o peso $\mathrm{x}$ gr. Sendo y gr $=$ número de $\mathrm{ME}$ de $\mathrm{NaOH}$ (y 0,004) usado e w a umidade higroscópica da terra, obtem-se para cálculo da fração argila por $100 \mathrm{gr}$ de terra seca a $110^{\circ}$, pela fórmula seguinte:

$$
\operatorname{argila} \%=250(\mathrm{x}-0,004 \mathrm{y} \text { gr }) \cdot \frac{100}{100-\mathrm{w}}
$$

A fração areia grossa tambem segue para a estufa a $110^{\circ}$ e assim obteremos o peso $z$

$$
\text { areia grossa } \%=5 \text { z. } \frac{100}{100-w}
$$

A terceira fração, que, na verdade, nos representa a soma de areia fina + limo, é obtida pela diferença seguinte: areia fina + limo $\%$

$$
=[100-[5 z+250(\mathrm{x} g r-0,004 \mathrm{gr} \mathrm{y})] \cdot] \cdot \frac{100}{100-\mathrm{w}}
$$

Assim foram obtidos os números que integram as nossas tabelas e gráficos de análise mecânica. 


\section{2. ${ }^{\circ}$ Método de análise mecânica para terras essencialmente argilosas, excetuando-se as terras roxas, em geral :}

Para proceder à análise mecânica deste segundo grupo, obedece-se à mesma marcha seguida para as arenosas, com a diferença de haver necessidade de se usar, geralmente, maior quantidade de solução de carbonato de amônio, e tambem um número maior de miliquivalentes de $\mathrm{NaOH}$; em alguns casos 10 e mesmo mais.

\section{3. ' Método de análise para as terras roxas, em geral :}

Tratando-se desse tipo de solo, geralmente se torna necessário duplicar ou mesmo triplicar a quantidade de solução de carbonato de amônio.

Os miliquivalentes de $\mathrm{NaOH}$ não devem, de ordinário, ultrapassar de cinco, pois as suspensões desse tipo de solo são extremamente sensiveis aos iônios $\mathrm{OH}$ - Neste ponto, o material é levado a uma cápsula de porcelana de mais ou menos $15 \mathrm{~cm}$ de diâmetro, antes de ser passado pela peneira de $0,2 \mathrm{~mm}$. Na cápsula, a suspensão sofre um destorroamento mecânico, porem delicado, contra as paredes da mesma, com a ajuda de uma mão de gral, revestida com borracha bem mole. Esse processo é necessário para finalizar a peptização ou defloculação dos conglomerados (pseudo areia), que em geral são fortemente cimentados pelas partes superfinas, constituidas essencialmente de hidróxidos de ferro e alumínio. Ao tentar-se conseguir essa peptização total, unicamente com auxílio de carbonato de amônio, dispende-se muito tempo. No restante, a técnica é idêntica à dos métodos anteriores.

\section{ANÁLISE MECÂNICA NATURAL}

(Separação da "fração argila" que se encontra naturalmente peptizada no solo)

Representa grande interesse prático e teórico, a dosagem da argila que se encontra no meio edáfico no estado natural de suspensão, ou facilmente peptizavel só com emprego de áqua destilada. Vários são os fenômenos de magna importância, estreitamente relacionados com a maior ou menor rapidez do percurso e de floculação das micelas de argila no solo. Como exemplo interessante citamos a presença de um horizonte iluvial fortemente adensado, em muitos tipos de nossos solos, devido ao acúmulo de partículas finas ou argila, as quais o tornam imper- 


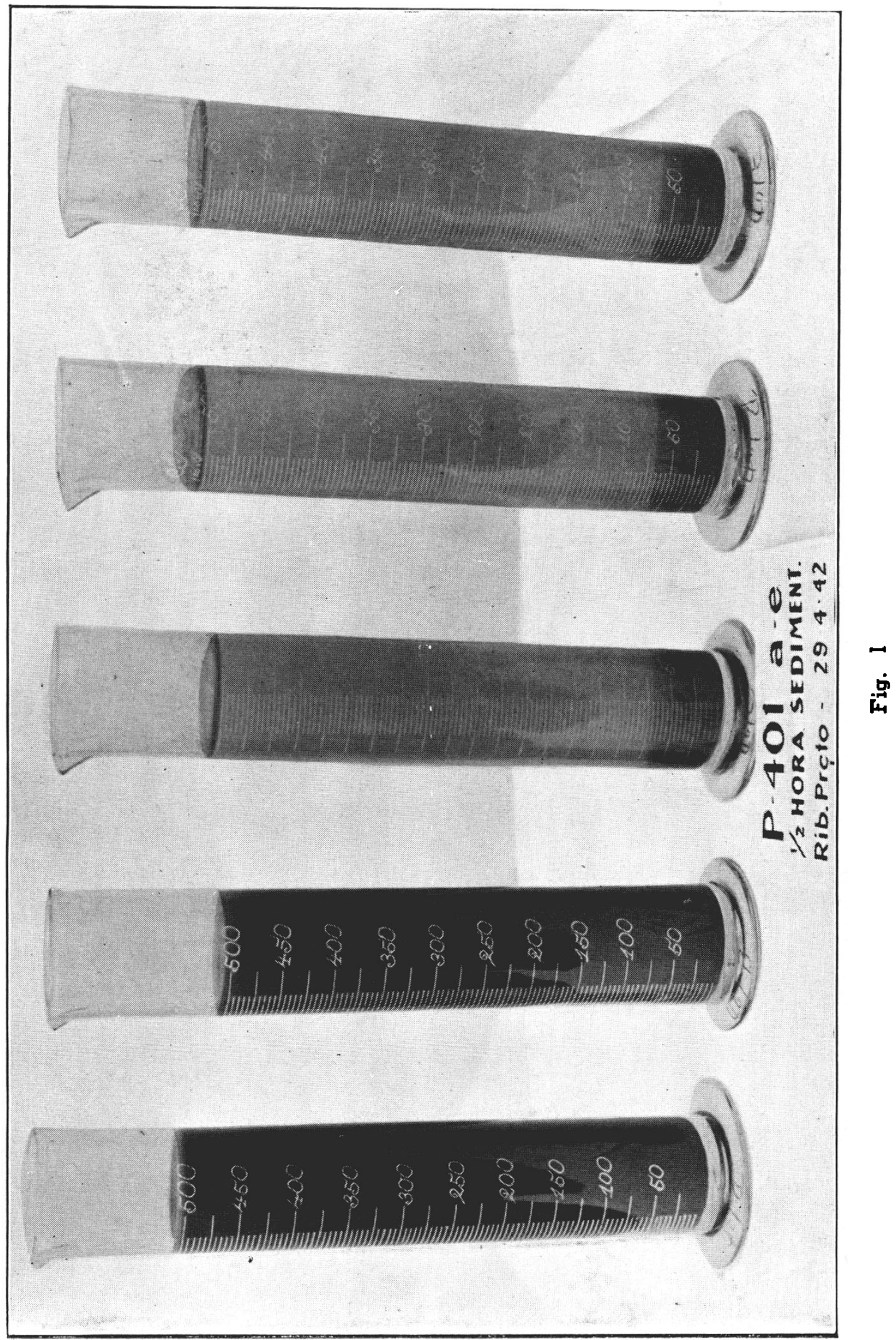


meavel à água e às raízes das plantas. Estes horizontes comumente podem ser localizados em profundidades que variam de 20 a $70 \mathrm{~cm}$ se o solo for relativamente argiloso; a sua espessura oscila entre poucos centímetros e um número superior a $20 \mathrm{~cm}$. Quando situados próximo à superfície, e sendo de espessura reduzida, podem facilmente ser removidos com auxílio de um sub-solador. Esse processo, às vezes, representa importância de carater vital para as plantas, pois não só lhes faculta um aprofundamento maior das raizes como tambem coloca à disposição das mesmas maior quantidade de água, em virtude de absorver maior volume desse líquido, procedente das chuvas. Por outro lado, diminue o volume das enxurradas, auxiliando assim a conservação da fertilidade do solo. Todos esses fenômenos são consequência da maior ou menor rapidez no arrastamento e floculação das micelas contidas no perfil do solo. A quantidade de argila naturalmente em suspensão no solo é muito variável. Em alguns casos chega a ser igual a zero, enquanto que em outros pode atingir um número relativamente elevado. De ordinário, não se encontram, no primeiro horizonte do solo, valores nulos, isto é, iguais a zero; todavia, são comuns em horizontes situados mais abaixo.

fenômeno (floculação completa) não escolhe tipo de solo. Pode apresentar-se em qualquer um, não obstante existirem tipos preferenciais, como, por exemplo, os horizontes dos perfís da terra roxa legítima, situados, de ordinário, a $60 \mathrm{~cm}$ abaixo da superfície. A figura 1 mostra a floculação completa da argila, nos horizontes c, d e e do perfil 401 a-e, após meia hora de repouso. Esse perfil foi tomado em RibeirãoPreto, Fazenda Experimental São José, numa altitude de 687 metros.

A relação percentual existente entre a argila total e a natural representa um fator importante, do qual nos servimos para determinar os índices relativos à resistência contra a erosão.

É óbvio que, quanto mais resistentes os agregados do solo, tanto menos argila dispersa possue e tanto menor o arrastamento das partículas finas. Outra circunstância, que põe em evidência a maior ou menor possibilidade da dispersão dos agregados, é o fato de ser preciso o emprego de diferentes métodos para a sua peptização na análise mecânica total. Ficou patente, pelos métodos descritos acima, que, em certas ocasiões, se torna necessário recorrer ao destorroamento mecânico, embora leve. A análise mecânica natural obedece a um único método, - qual descrevemos a seguir: 
Em um vaso de Boêmia de $600 \mathrm{cc}$ tomam-se $20 \mathrm{gr}$ de solo seco ao ar. Adicionam-se, aproximadamente, $100 \mathrm{cc}$ de água destilada; agita-se o copo levemente e deixa-se em repouso por 24 horas. A seguir, passa-se a suspensão por uma peneira de $0,2 \mathrm{~mm}$ e, com auxílio de um bastão de vidro, munido de borracha numa das extremidades e água destilada, lava-se até que o líquido comece a passar praticamente cristalino. No mais, procede-se de forma idêntica à descrita para a análise mecânica total.

O gráfico n. ${ }^{\circ} 1$ apresenta os valores médios, obtidos na análise mecânica total, dos grandes tipos de solo do Estado. Esses valores são calculados por $100 \mathrm{gr}$ de solo seco a $110^{\circ} \mathrm{C}$. A escala granulométrica adotada é a de Atterberg.

Pelo estudo desse gráfico, obtemos um conceito 'exato da variação da composição mecânica dos nossos grandes tipos de solo.

Neste trabalho vamos vistoriar, quase que exclusivamente, a fração menor do que dois microns (fração argila); a fração maior, ou esqueleto propriamente dito, deixamos de lado; a sua função, como parte ativa do solo, pouco importa no momento.

\section{A FRAÇÃO ARGILA DO SOLO}

Hoje-em-dia, estuda-se com intensidade crescente essa fração do solo, seja sob o ponto de vista estático ou de fundações; sob o ponto de vista rodoviário ou da agro-geologia; ou ainda sob o ponto de vista cerâmico ou para estudo dos fenômenos coloidais em geral.

Conquanto o nosso problema a resolver tenha carater essencialmente agro-geológico, é notório que o estudo das propriedades gerais da fração argila pode servir, em comum, para todas as questões citadas. Já descrevemos a separação da fração argila; vamos, em seguida, estudá-la quimicamente.

Nas pesquisas científicas do solo, essa fração é tambem chamada "complexo coloidal do solo". Os métodos químicos empregados para - estudo do complexo podem ser divididos da seguinte forma: 1.0 , método químico para o estudo da composição química total do complexo ; 2. ${ }^{\circ}$, método químico para a destruição integral ou parcial do mesmo; 3. ${ }^{\circ}$, método químico (ou melhor físico-químico) para o estudo da estrutura externa da micela ou camada 'de Helmholz, sede dos fenômenos de troca do complexo sortivo; e, $4 .^{\circ}$, método de fixação de iônios na camada dupla de Helmholz. 


\section{Método químico usado para a destruição total do complexo argila :}

Ataque do solo - (Neste ataque são destruidos os silicatos hidratados de alumínio, óxidos hidratados de ferro, alumínio e manganês, magnetita e ilmenita).

Em uma cápsula pequena de porcelana, coloca-se l gr de terra fina, de amostra previamente bem misturada e o mais homogênea possivel. Juntam-se $5 \mathrm{cc}$ de ácido sulfúrico concentrado e leva-se ao banho de areia bem quente. $O$ ácido sulfúrico ataca e desorganiza todo o complexo de argila, produzindo densas fumaças brancas (de $\mathrm{SO}_{3}$ ). Quando - material atacado estiver aparentemente seco, mas produzindo ainda fumaças, retira-se do banho e, depois de frio, juntam-se 3 cc de água oxigenada (100 a 130 volumes). Leva-se novamente ao banho de areia, agora com fogo brando, até que a violenta reação de oxigênio se produza, oxidando e destruindo toda a matéria orgânica. Aumenta-se o fogo do banho de areia, aquecendo-se fortemente, até que não haja mais desprendimento de fumaças brancas. Retira-se do banho e juntam-se, mais uma vez, $3 \mathrm{cc}$ de água oxigenada, repetindo-se a operação anterior, até secura completa da preparação. Depois de retirado do banho e resfriado, juntam-se $10 \mathrm{Cc}$ de ácido clorídrico concentrado e leva-se de novo ao banho de areia, desta vez, porem, com fogo ainda mais brando, conservando-se deste modo até a secura completa. Esta última operação pode ser feita em banho-maria. Depois de completamente seco, juntamse à cápsula $30 \mathrm{cc}$ de solução de $\mathrm{HCl}$ a $10 \%$ e aquece-se em bico de gás até a fervura; apaga-se o bico, logo que esteja fervendo por alguns. instantes. Em seguida, passa-se por um filtro livre de cinzas (isento de sílica), recolhendo-se o filtrado em um balão calibrado de $200 \mathrm{cc}$; lavase muito bem a cápsula e recolhem-se as águas de lavagem sobre o filtro. Lava-se tambem o filtro até que o líquido de lavagem não apresente mais reação ácida. Completa-se o volume com água destilada, e este soluto servirá para a determinação do ferro, alumínio e titânio. O papel de filtro com o resíduo são transferidos depois para um copo de vidro neutro (Pyrex ou Schott, etc.) de $100 \mathrm{cc}$ mais ou menos. Esta parte vai servir para a determinação da sílica.

1 - Determinação do ferro $\left(\mathrm{Fe}_{2} \mathrm{O}_{3}\right)$ - Tomam-se $50 \mathrm{cC}$ dos $200 \mathrm{cc}$ do filtrado e colocam-se em um copo de $300 \mathrm{cc}$ mais ou menos ; adicionam-se $5 \mathrm{cc}$ de $\mathrm{HCl}$ concentrado e ferve-se sobre bico de Bunsen. Assim que esteja fervendo, tira-se do fogo e imediatamente se junta, gota a gota, uma solução de cloreto estanhoso a 5\% em solução de $\mathrm{HCl}$ 
a $10 \%$, até que a coloração amarela do cloreto férrico desapareça ; juntam-se ainda mais 1 ou 2 gotas da solução. Resfria-se ligeiramente e juntam-se $4 \mathrm{cc}$ de uma solução saturada de bicloreto de mercúrio. Aparecerá logo um precipitado branco de cloreto mercuroso, devido ao pequeno excesso de cloreto estanhoso. Se em vez de precipitado branco se formar um precipitado escuro é porque o excesso de cloreto estanhoso foi muito grande e, nesse caso, deve-se abandonar a análise e recomeçar com nova solução. Depois dessa operação junta-se água destilada até um volume de 100 a $120 \mathrm{cc}$ e adicionam-se $3 \mathrm{cc}$ de solução de ácido fosfórico (partes iguais de solução saturada de ácido fosfórico e água). Titula-se a frio com bicromato de potássio decinormal, usandose como indicador 6 gotas de solução $1 \%$ de difenilamina em ácido sulfúrico concentrado.

Cálculo - Usando-se todas as quantidades indicadas no método, os centímetros cúbicos gastos de bicromato de potássio menos 0,1 cc multiplicado por 3,2 dão exatamente gramas de $\mathrm{Fe}_{2} \mathrm{O}_{3}$ por 100 gramas de terra. É necessário descontar-se 0,1 cc dos centímetros cúbicos de bicromato, uma vez que 6 gotas do indicador necessitam de 0,1 cc de bicromato para sua própria oxidação.

\section{2 - Determinação do alumínio $\left(\mathrm{Al}_{2} \mathrm{O}_{3}\right)$ - Dos $200 \mathrm{cc}$ do} filtrado, tomam-se $100 \mathrm{cc}$ e colocam-se em um balão de $150 \mathrm{cc}$ jưntamente com $10 \mathrm{cc}$ de solução de $\mathrm{NaOH} 5 \mathrm{~N}$ e leva-se ao fogo, fervendo-se durante 2 a 3 minutos. Retira-se do fogo, resfria-se completamente, faz-se o volume e filtra-se. Do filtrado, tomam-se $50 \mathrm{cc}$ e colocam-se em um copo de $300 \mathrm{cc}$ mais ou menos, com $1 \mathrm{cc}$ de solução de bromotimol azul a $0,04 \%$ e junta-se aos poucos $\mathrm{HCl} 2,5 \mathrm{~N}$ até a mudança da coloração azul para amarelo. Em seguida junta-se, gota a gota, uma solução N/10 de $\mathrm{NaOH}$, até que a coloração se torne francamente azul, notando-se ainda a formação de um precipitado branco de hidróxido de alumínio. Junta-se então uma quantidade conhecida de solução titulada de $\mathrm{HCl}$ $\mathrm{N} / 10$, suficiente para dissolver completamente o precipitado de hidróxido de alumínio. A coloração torna-se de novo amarela. Juntam-se agora $20 \mathrm{cc}$ de solução saturada de oxalato de sódio. Junta-se mais 1 cc de solução de bromotimol azul e titula-se com solução titulada de $\mathrm{NaOH}$ $\mathrm{N} / 10$, até coloração francamente azul.

Cálculo - Os centímetros cúbicos adicionados de $\mathrm{HCl} \mathrm{N/10} \mathrm{menos} \mathrm{os}$ centímetros cúbicos gastos de $\mathrm{NaOH} \mathrm{N} / 10$, multiplicados por 1,02, nos darão gramas de $\mathrm{Al}_{2} \mathrm{O}_{3}$ por $100 \mathrm{gr}$ de terra. 


\section{3 - Determinação do titânio $\left(\mathrm{T}^{\prime} \mathrm{O}_{2}\right)$-..- Tomam-se os $50 \mathrm{cc}$} restantes dos $200 \mathrm{cc}$ do filtrado e colocam-se em um balão de Kjeldahl de $300 \mathrm{cc}$, juntamente com $5 \mathrm{cc}$ de $\mathrm{H}_{2} \mathrm{SO}_{4}$ concentrado; a evaporação é feita até que apareçam fumaças brancas de anídrido sulfúrico e continuase o aquecimento ainda por mais alguns minutos, findo os quais, retira-se o balão do fogo e deixa-se resfriar. Depois de frio, juntam-se com cautela, mais ou menos, $50 \mathrm{cc}$ de água. Aquece-se novamente, até que desapareça a turvação, ficando o líquido completamente transparente. Transvasase depois para um balão calibrado de 100 cc, lavando-se o Kjeldahl e juntam-se ao balão as águas de lavagens.

Refria-se completamente e junta-se 1 cc de água oxigenada a 100 v, completando-se depois o volume e agitando-se fortemente. A cor amarela, mais ou menos avermelhada do ácido pertitânico, aparece, permanecendo fixa por muito tempo. Procede-se, por fim, à colorimetragem, usando-se sempre padrões feitos nas mesmas condições, isto é, seguindo toda a marcha da operação.

Para colorimetrar usamos o colorímetro fotoelétrico de Hellige com filtro azul e cubeta de $40 \mathrm{~mm}$ de espessura.

4 - Determinação da sílica $\left(\mathrm{SiO}_{2}\right)$ - Ao copo onde foi colocado o papel de filtro com o resíduo da filtração do ataque são adicionados $50 \mathrm{cc}$ de solução de carbonato de sódio a $5 \%$ e 5 cc de solução normal de $\mathrm{NaOH}$. Leva-se depois ao fogo brando, regulado justamente para o ponto de fervura e deixa-se ferver por espaço de duas horas. Junta-se de quando em quando um pouco de água destilada, para manter-se o mesmo volume. Findo esse prazo, retira-se do fogo e deixa-se resfriar. Filtra-se depois para um balão calibrado de $250 \mathrm{cc}$, passando-se por um filtro maior e tendo-se o cuidado de remover o filtro do copo para dentro do outro, para o que se usa uma pequena pinça. Lava-se muito bem o copo e o filtro, recolhendo-se tudo no balão. Depois de lavados os filtros, completa-se o volume e procede-se da seguinte maneira: tomam-se $5 \mathrm{cc}$ do filtrado e colocam-se em um balão calibrado de $100 \mathrm{cc}$, juntando-se áqua destilada até mais ou menos 80 cc. Adicionam-se, então, $10 \mathrm{Cc}$ do reativo sulfo molíbdico e completa-se o volume. Comparase a cor, depois de 2 a 3 minutos, com padrões feitos nas mesmas condições. A coloração se mantem inalterada durante 30 minutos depois de sua preparação.

Tambem aquí usamos, o fotômetro de Hellige. Fazemos uma série de padrões e, com os micro-arnperes encontrados no galvanômetro, construimos sobre papel milinetrado uma curva padrão, que servirá 
para todas as determinações futuras. A determinação dos padrões deve ser feita seguindo-se toda a marcha do método, porque o vasilhame usado, embora de vidro neutro, sempre perde uma certa quantidade de sílica.

O reativo sulfo molíbdico é preparado do seguinte modo: a 600 cc de solução de molibdato de amônio a 10\%, juntam-se $150 \mathrm{cc}$ de solução de ácido sulfúrico a $20 \%$ e agita-se. Este reativo conserva-se bem por espaço de tempo razoavel.

Entre os nossos perfís mais caraterísticos de cada grande tipo de solo, escolhemos alguns ao acaso, a-fim-de mostrar as oscilações que podem ser encontradas com relação à composição total do complexo. A tabela 1 contem os citados valores.

\section{2. ${ }^{\circ}$ Método químico usado para a destruição parcial do com- plexo argila-humus :}

Neste segundo método, temos em vista somente a destruição dos óxidos hidratados de ferro, alumínio, manganês, sílica livre, magnetita, ilmenita, etc. Ficam sem sofrer ataque os silicatos hidratados de alumínio.

Leva-se a um banho de areia 1 grama de amostra bem homogênea de terra fina, colocada em uma cápsula de porcelana juntamente com 5 cc de ácido clorídrico concentrado. Após a secagem, retira-se do banho e juntam-se $5 \mathrm{cc}$ de água oxigenada (100 a 130 volumes) e leva-se outra vez ao banho de areia, até secar de novo. Uma nova porção de água oxigenada é juntada do mesmo modo. Essas operações (tratamentos com $\mathrm{HCl} e \mathrm{H}_{2} \mathrm{O}_{2}$ ) são repetidas duas ou três vezes ainda, conforme a quantidade de argila que a amostra contem. Por fim, juntam-se $10 \mathrm{cc}$ de ácido clorídrico com fogo brando e depois de seco retira-se do banho; juntam-se $30 \mathrm{cc}$ de solução a $10 \%$ de ácido clorídrico e aquece-se em bico de gás até a fervura. Em seguida, passa-se por um filtro livre de cinzas (isento de sílica), recolhendo-se o filtrado em um balão calibrado de $200 \mathrm{cc}$; lava-se muito bem a cápsula e recolhem-se as águas de lavagem sobre o filtro. Lava-se tambem o filtro até que o líquido de lavagem não apresente mais reação ácida. Completa-se o volume com água destilada e este soluto servirá para se determinar o ferro e o alumínio. $O$ papel de filtro com o resíduo é transferido para um copo de vidro neutro de $100 \mathrm{cc}$. Esta parte vai servir para se determinar a sílica.

Determinaram-se o ferro, alumínio e sílica, pelos processos já descritos quando se tratou do ataque com ácido sulfúrico. 


\section{3. - Método químico (f́ísico-químico) para a determinação da} composição da camada de Helmholz (Determinação de catiônios trocaveis) :

Como exemplo de cada grande tipo de solo, figuram quase todos os perfís já contidos nos quadros da análise química total do complexo.

No estudo dos catiônios trocaveis, usamos, como líquido extrator, as soluções de $\mathrm{NH}_{4} \mathrm{Cl} \mathrm{N} / 1, \mathrm{KCl} \mathrm{N} / 1, \mathrm{HNO}_{3} \mathrm{~N} / 5$ e $\left(\mathrm{CH}_{3} \mathrm{COO}\right)_{2} \mathrm{Ca} \mathrm{N} / 1$. A percolação foi a técnica empregada (7). Usamos duas percolações e o valor final da reação foi calculado pela fórmula Vageler (8).

A relação entre solo e líquido sempre foi de 1:10. Para a extração do iônio $\mathrm{Ca}++$ trocavel foi preferida a solução de $\mathrm{NH}_{4} \mathrm{Cl} \mathrm{N} / 1$; para a do iônio $\mathrm{K}^{+}$foi usado $\circ \mathrm{HNO}_{3} \mathrm{~N} / 5$; para a determinação de $\AA \mathrm{l}+++$ trocavel foi empregada a solução de $\mathrm{KCl} \mathrm{N} / 1$ e para a de $\mathrm{H}+$ trocavel foi utilizada a solução N/1 de acetato de cálcio. Para melhores esclarecimentos, aconselhamos consultar (5, 9, 10, 11, 12, 13 e 14).

\section{4. ${ }^{\circ}$ Método de fixação do iônio $\mathrm{Ca}^{++}$no complexo argila-humus :}

O método de fixação por nós empregado é o seguinte: em um tubo percolador (7) são colocados $10 \mathrm{gr}$ de solo seco ao ar ; fazem-se passar, percolando, $100 \mathrm{cc}$ da solução N/1 do catiônio a fixar. A fixação consta de $\mathrm{Ca}++$ em forma de cloreto. A tabela 5 nos mostra a fixação na terra-roxa, em virtude de tratar-se da que se nos apresenta com menores índices da relação: $\frac{\mathrm{SiO}_{2}}{\mathrm{R}_{2} \mathrm{O}_{3}}$.

A análise química total do complexo argila possibilita o cálculo das relações moleculares entre a sílica e os sesquióxidos. Já com estas relações podemos ter idéia do comportamento físico-químico do complexo argila. Em geral, a relação $\frac{\mathrm{SiO}_{2}}{\mathrm{R}_{2} \mathrm{O}_{3}}$, sendo menor do que 2, o poder sortivo do complexo é reduzido; na maior parte dos casos não atinge $10 \mathrm{ME} \% \mathrm{gr}$. Quando essa relação é maior do que três, pode alcançar $100 \mathrm{ME}$, como no caso de certas argilas montmorriloníticas. A tabela 1, ilustra os índices das relações entre $\mathrm{SiO}_{2}$ e sesquióxidos. Entretanto, em certos casos, devem eles ser vistos de forma diversa, pois, como se observa pelas análises, são em geral muito pequenos, a ponto de atingir 0,3 na terra-roxa. 
A tabela 5 nos mostra que, a-pesar-de esse índice ser tão reduzido $(0,3)$ na terra roxa, o poder sortivo para o iônio Ca ${ }^{++}$não é tão insignificante como devia de ser.

Neste caso, afigura-se-nos que, no estado em que os óxidos hidratados de ferro e alumínio se encontram na terra-roxa, possuem certo poder de fixação para com os catiônios.

As tabelas da análise química dão-nos boa idéia da constituição química do complexo; quer seja na análise total, quer na dos iônios trocaveis. Nelas encontramos os valores médios, máximos e mínimos. Podemos tambem analisar por aí a variação dos índices $\mathrm{SiO}_{2}$ sobre sesquióxidos dos vários grandes tipos de solo do Estado, a constituição da camada de Helmholz e o menor ou maior teor deste ou daquele catiônio. Na tabela 4 dos catiônios trocaveis, na penúltima coluna, apresentamos tambem o Hy (higroscopicidade) segundo Mitscherlich; é uma constante de valor e que está intimamente relacionada com a estrutura físico-química do complexo argila-humus. Neste trabalho não vamos entrar em considerações sobre o valor $\mathrm{Hy}$; isso fará parte de um outro a ser publicado oportunamente.

A tabela 2 estampa os teores em $\mathrm{SiO}_{2}, \mathrm{Al}_{2} \mathrm{O}_{3}$ e $\mathrm{Fe}_{2} \mathrm{O}_{3}$ em estado livre no solo, isto é, na forma de seus óxidos hidratados. A tabela 3 nos dá idéia da percentagem de silicatos hidratados de alumínio, calculada na forma de caolinita $\left(\mathrm{Al}_{2} \mathrm{O}_{3}, 2 \mathrm{SiO}_{2}, 2 \mathrm{H}_{2} \mathrm{O}\right)$ por $100 \mathrm{gr}$ de terra fina e $100 \mathrm{gr}$ de argila. A tabela 5, finalmente, ilustra o poder de fixação dos iônios $\mathrm{Ca}++$ pelo complexo sortivo da terra roxa legítima.

\section{ESTUDOS ROENTGENOGRÁFICOS DA "FRAÇÃO ARGILA" DOS SOLOS DO ESTADO}

Não faz ainda uma dezena de anos que se emprega a espectrografia por meio dos raios $\mathrm{X}$, nas pesquisas da estrutura física das redes cristalinas dos minerais de argila existentes no solo, os quais constituem essencialmente a "fração argila" ou "colóide do solo". A utilização dos raios $\mathrm{X}$, ou roentgenografia, para os estudos dos minerais de argila, veio facilitar enormemente e, mesmo, resolver problemas que até então eram insoluveis. Este método pesquisa o material sem, contudo, modificar a sua estrutura física ; baseia-se na refração dos raios $\mathrm{X}$ (de comprimento de onda, entre 1 e 2 A) pelas redes cristalinas do material em questão. O primeiro método empregado necessitava sempre de cristais relativamente grandes, sobre os quais, em determinadas orientações, incidia um jato de raios X. Estes, após sofrerem a refração, eram rece- 
T A B E L A 1

ANÁL. QUÍM. TOTAL DO COMPLEXO ARGILA POR $100 \mathrm{gr}$ DE SOLO SECO A $110^{\circ} \mathrm{C}$. Valores médios, máximos e mínimos

SOLOS SOBRE O ARQUEANO

\begin{tabular}{|c|c|c|c|c|c|c|}
\hline & $\mathrm{SiO}_{2}$ & $\mathrm{Al}_{2} \mathrm{O}_{3}$ & $\mathrm{Fe}_{2} \mathrm{O}_{3}$ & $\mathrm{TiO}_{2}$ & $\begin{array}{l}\mathrm{H}_{2} \mathrm{O} \text { de } \\
\text { consti- } \\
\text { tuição }\end{array}$ & $\begin{array}{l}\text { relação: } \\
\left.{ }^{\star}\right) \frac{\mathrm{SiO}_{2}}{\mathrm{R}_{2} \mathrm{O}_{3}}\end{array}$ \\
\hline $\begin{array}{l}\text { Média } \ldots \ldots \ldots \ldots \ldots \\
\text { Máxima } \ldots \ldots \ldots \ldots \ldots \\
\text { Mínima } \ldots \ldots \ldots \ldots \ldots\end{array}$ & $\begin{array}{r}10,2 \\
17,0 \\
5,0\end{array}$ & $\begin{array}{r}13,9 \\
25,0 \\
5,0\end{array}$ & $\begin{array}{l}4,4 \\
9,0 \\
2,0\end{array}$ & $\begin{array}{l}0,6 \\
1,0 \\
0,3\end{array}$ & $\begin{array}{r}6,1 \\
12,0 \\
2,8\end{array}$ & $\begin{array}{l}1,10 \\
1,60 \\
0,52\end{array}$ \\
\hline
\end{tabular}

SOLOS SOBRE O GLACIAL

\begin{tabular}{l|r|r|r|r|r|r}
\hline Média $\ldots \ldots \ldots \ldots \ldots$ & 14,0 & 24,0 & 9,0 & 1,0 & 11,0 & 0,49 \\
Máxima $\ldots \ldots \ldots \ldots \ldots$ & 16,4 & 29,0 & 15,0 & 1,2 & 20,0 & 0,67 \\
Mínima $\ldots \ldots \ldots \ldots \ldots$ & 10,0 & 22,0 & 6,0 & 0,9 & 7,0 & 0,29 \\
\hline
\end{tabular}

SOLOS SOBRE O CORUMBATAI

\begin{tabular}{l|r|r|r|r|r|r}
\hline Média $\ldots \ldots \ldots \ldots \ldots \ldots$ & 12,3 & 21,0 & 13,0 & 1,1 & 10,0 & 0,63 \\
Máxima $\ldots \ldots \ldots \ldots \ldots \ldots$ & 19,0 & 17,0 & 17,0 & 1,5 & 13,0 & 1,30 \\
Mínima $\ldots \ldots \ldots \ldots \ldots \ldots$ & 7,0 & 25,0 & 9,0 & 0,7 & 7,0 & 0,35 \\
\hline
\end{tabular}

SOLOS SOBRE O BOTUCATÚ (LAVA) TERRA ROXA LEGÍTIMA

\begin{tabular}{l|r|r|r|r|r|r}
\hline Média $\ldots \ldots \ldots \ldots \ldots$ & 11,1 & 24,4 & 30,6 & 7,1 & 14,0 & 0,54 \\
Máxima $\ldots \ldots \ldots \ldots \ldots$ & 14,0 & 26,0 & 34,2 & 9,5 & 16,7 & 1,10 \\
Mínima $\ldots \ldots \ldots \ldots \ldots$ & 6,6 & 22,0 & 28,2 & 6,0 & 12,0 & 0,30 \\
\hline
\end{tabular}

SOLOS SOBRE O BOTUCATÚ (ARENITO)

\begin{tabular}{l|l|l|l|l|l|l|l}
\hline Média $\ldots \ldots \ldots \ldots \ldots$ & 3,8 & 4,6 & 2,1 & 0,8 & 4,0 & 0,73 \\
Máxima $\ldots \ldots \ldots \ldots \ldots$ & 7,0 & 9,0 & 3,6 & 1,2 & 9,6 & 1,20 \\
Mínima $\ldots \ldots \ldots \ldots \ldots$ & 0,5 & 2,2 & 0,5 & 0,5 & 0,6 & 0,10 \\
\hline
\end{tabular}

SOLOS SOBRE O BAURÚ INFERIOR (?) CAIUÁ (?)

\begin{tabular}{l|l|l|l|l|l|l}
\hline Média $\ldots \ldots \ldots \ldots \ldots \ldots$ & 3,4 & 4,4 & 1,2 & 0,4 & 2,0 & 0,53 \\
Máxima $\ldots \ldots \ldots \ldots \ldots$ & 4,2 & 4,9 & 1,3 & 0,5 & 2,5 & 0,60 \\
Mínima $\ldots \ldots \ldots \ldots \ldots$ & 2,7 & 3,7 & 1,0 & 0,3 & 1,4 & 0,33 \\
\hline
\end{tabular}

SOLOS SOBRE O BAURÚ SUPERIOR

\begin{tabular}{l|l|l|l|l|l|l}
\hline Média $\ldots \ldots \ldots \ldots \ldots \ldots$ & 4,8 & 4,1 & 1,4 & 0,4 & 2,3 & 0,91 \\
Máxima $\ldots \ldots \ldots \ldots \ldots$ & 9,5 & 8,4 & 2,6 & 0,7 & 4,5 & 2,30 \\
Mínima $\ldots \ldots \ldots \ldots \ldots$ & 1,3 & 1,7 & 0,4 & 0,3 & 1,0 & 0,45 \\
\hline
\end{tabular}

*) $\mathrm{R}_{2} \mathrm{O}_{3}=\mathrm{Al}_{2} \mathrm{O}_{3}+\mathrm{Fe}_{2} \mathrm{O}_{3}+\mathrm{TiO}_{2}$ 


\section{T A B E L A 2}

ANAL. QUÍM. PARCIAL DO COMPLEXO ARGILA POR $100 \mathrm{gr}$ DE SOLO SECO A $110^{\circ} \mathrm{C}$. Valores médios, máximos e mínimos

SOLOS SOBRE O ARQUEANO

\begin{tabular}{|c|c|c|c|c|}
\hline & $\mathrm{SiO}_{2}$ & $\mathrm{Al}_{2} \mathrm{O}_{3}$ & $\mathrm{Fe}_{2} \mathrm{O}_{3}$ & $\mathrm{TiO}_{2}$ \\
\hline $\begin{array}{l}\text { Média } \ldots \ldots \ldots \ldots \ldots \ldots \ldots \ldots \ldots \ldots \ldots \ldots \ldots \ldots \ldots \\
\text { Máxima } \ldots \ldots \ldots \ldots \ldots \ldots \ldots \ldots \ldots\end{array}$ & $\begin{array}{r}6,0 \\
14,0 \\
1,5\end{array}$ & $\begin{array}{r}6,0 \\
10,2 \\
3,9\end{array}$ & $\begin{array}{l}4,1 \\
9,0 \\
2,2\end{array}$ & $\begin{array}{l}0,6 \\
1,0 \\
0,3\end{array}$ \\
\hline
\end{tabular}

SOLOS SOBRE O GLACIAL

\begin{tabular}{l|l|l|r|r}
\hline Média $\ldots \ldots \ldots \ldots \ldots \ldots \ldots \ldots \ldots$ & 8,4 & 20,3 & 9,7 & 1,0 \\
Máxima $\ldots \ldots \ldots \ldots \ldots \ldots \ldots \ldots$ & 9,2 & 23,7 & 12,0 & 1,2 \\
Mínima $\ldots \ldots \ldots \ldots \ldots \ldots \ldots \ldots \ldots$ & 8,0 & 17,2 & 8,5 & 0,9 \\
\hline
\end{tabular}

SOLOS SOBRE O CORUMBATAf

\begin{tabular}{l|r|r|r|r}
\hline Média $\ldots \ldots \ldots \ldots \ldots \ldots \ldots \ldots \ldots$ & 9,0 & 8,3 & 6,5 & 1,1 \\
Máxima $\ldots \ldots \ldots \ldots \ldots \ldots \ldots$ & 13,0 & 16,0 & 10,9 & 1,5 \\
Mínima $\ldots \ldots \ldots \ldots \ldots \ldots \ldots \ldots \ldots$ & 7,0 & 3,0 & 1,6 & 0,7 \\
\hline
\end{tabular}

") SOLOS SOBRE O BOTUCATÚ (LAVA) - TERRA ROXA LEGITIMA

\begin{tabular}{l|l|l|l|l}
\hline Média $\ldots \ldots \ldots \ldots \ldots \ldots \ldots \ldots$ & 2,7 & 17,8 & 29,3 & 7,1 \\
Máxima $\ldots \ldots \ldots \ldots \ldots \ldots \ldots \ldots$ & 6,3 & 21,0 & 33,9 & 9,5 \\
Mínima $\ldots \ldots \ldots \ldots \ldots \ldots \ldots$ & 0,2 & 15,5 & 27,5 & 6,0 \\
\hline
\end{tabular}

SOLOS SOBRE O BOTUCATÚ (ARENITO)

\begin{tabular}{l|l|l|l|l}
\hline Média $\ldots \ldots \ldots \ldots \ldots \ldots \ldots \ldots$ & 0,2 & 2,3 & 1,4 & 0,8 \\
Máxima $\ldots \ldots \ldots \ldots \ldots \ldots \ldots$ & 0,7 & 2,9 & 2,2 & 1,2 \\
Mínima $\ldots \ldots \ldots \ldots \ldots \ldots \ldots$ & 0,0 & 1,7 & 1,0 & 0,5 \\
\hline
\end{tabular}

SOLOS SOBRE O BAURÚ INFERIOR (?) CAIUA (?)

\begin{tabular}{l|l|l|l|l}
\hline Média $\ldots \ldots \ldots \ldots \ldots \ldots \ldots \ldots$ & 0,3 & 1,7 & 1,2 & 0,4 \\
Máxima $\ldots \ldots \ldots \ldots \ldots \ldots \ldots \ldots$ & 0,5 & 1,8 & 1,8 & 0,5 \\
Mínima $\ldots \ldots \ldots \ldots \ldots \ldots \ldots$ & 0,0 & 1,5 & 0,6 & 0,3 \\
\hline
\end{tabular}

SOLOS SOBRE O BAURÚ SUPERIOR

\begin{tabular}{l|l|l|l|l}
\hline Média $\ldots \ldots \ldots \ldots \ldots \ldots \ldots \ldots \ldots$ & 0,2 & 1,5 & 0,9 & 0,4 \\
Máxima $\ldots \ldots \ldots \ldots \ldots \ldots \ldots \ldots$ & 5,1 & 2,2 & 2,2 & 0,7 \\
Mínima $\ldots \ldots \ldots \ldots \ldots \ldots \ldots$ & 0,0 & 1,3 & 0,3 & 0,3 \\
\hline
\end{tabular}

*) Devemos considerar aquí somente a terra roxa da zona de Ribeirão Preto. 
T A B E L A 3

TEOR EM CAOLINITA NOS GRANDES TIPOS DE SOLO DO ESTADO Valores médios, máximos e mínimos

SOLOS SOBRE O ARQUEANO

\begin{tabular}{|c|c|c|}
\hline & $\begin{array}{l}\text { Caolinita por } 100 \mathrm{gr} \\
\text { de terra fina a } 110^{\circ} \mathrm{C}\end{array}$ & $\begin{array}{l}\text { Caolinita por } 100 \mathrm{gr} \\
\text { de argila a } 110^{\circ} \mathrm{C} .\end{array}$ \\
\hline $\begin{array}{l}\text { Média } \ldots \ldots \ldots \ldots \ldots \ldots \ldots \ldots \ldots \ldots \ldots \ldots \ldots \ldots \\
\text { Máxima } \ldots \ldots \ldots \ldots \ldots \ldots \ldots \ldots \ldots \ldots \ldots \\
\text { Mínima } \ldots \ldots \ldots \ldots \ldots \ldots \ldots \ldots\end{array}$ & $\begin{array}{r}15,0 \\
30,0 \\
4,0\end{array}$ & $\begin{array}{r}56,0 \\
100,0 \\
15,0 \\
\end{array}$ \\
\hline
\end{tabular}

SOLOS SOBRE O GLACIAL

\begin{tabular}{|c|c|c|}
\hline 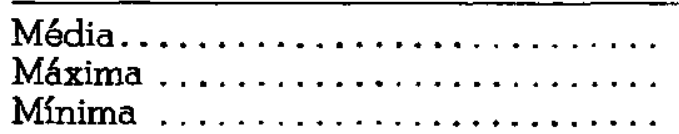 & $\begin{array}{r}14,0 \\
18,0 \\
9,0\end{array}$ & $\begin{array}{l}61,0 \\
80,0 \\
39,0\end{array}$ \\
\hline
\end{tabular}

SOLOS SOBRE O CORUMBATAf

\begin{tabular}{|c|c|c|}
\hline 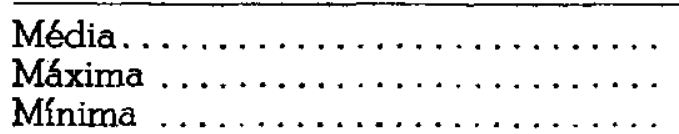 & $\begin{array}{l}16,0 \\
21,0 \\
10,0\end{array}$ & $\begin{array}{l}52,0 \\
67,0 \\
32,0\end{array}$ \\
\hline
\end{tabular}

*) SOLOS SOBRE O BOTUCATÚ (LAVA) TERRA ROXA LEGITTMA

\begin{tabular}{|c|c|c|}
\hline 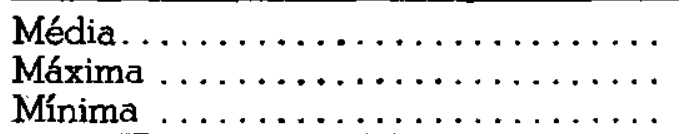 & $\begin{array}{r}15,0 \\
25,0 \\
4,5\end{array}$ & $\begin{array}{l}34,0 \\
57,0 \\
11,0\end{array}$ \\
\hline
\end{tabular}

SOLOS SOBRE O BOTUCATÚ (ARENITO)

\begin{tabular}{|c|c|c|}
\hline $\begin{array}{l}\text { Média } \ldots \ldots \ldots \ldots \ldots \ldots \ldots \ldots \ldots \ldots \ldots \ldots \ldots \\
\text { Máxima } \ldots \ldots \ldots \ldots \ldots \ldots \ldots \ldots \ldots \ldots \\
\text { Mínima } \ldots \ldots \ldots \ldots \ldots \ldots \ldots \ldots\end{array}$ & $\begin{array}{l}7,0 \\
9,0 \\
6,0\end{array}$ & $\begin{array}{l}66,0 \\
90,0 \\
62,0\end{array}$ \\
\hline
\end{tabular}

SOLOS SOBRE O BAURÚ . INFERIOR (?) CAIUÁ (?)

\begin{tabular}{|c|c|c|}
\hline 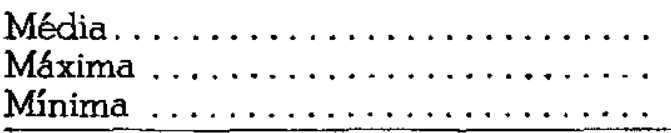 & $\begin{array}{l}7,0 \\
8,0 \\
4,0\end{array}$ & $\begin{array}{l}48,0 \\
57,3 \\
33,0\end{array}$ \\
\hline
\end{tabular}

SOLOS SOBRE O BAURÚ SUPERIOR

\begin{tabular}{|c|c|c|}
\hline 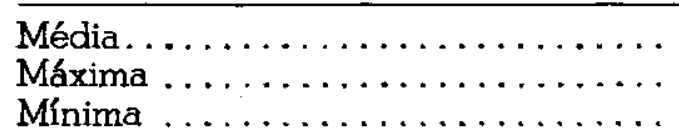 & $\begin{array}{r}7,0 \\
12,0 \\
1,0\end{array}$ & $\begin{array}{r}60,0 \\
100,0 \\
8,0\end{array}$ \\
\hline
\end{tabular}

*) Devemos considerar aquí somente a terra roxa da zona de Ribeirão Preto. 


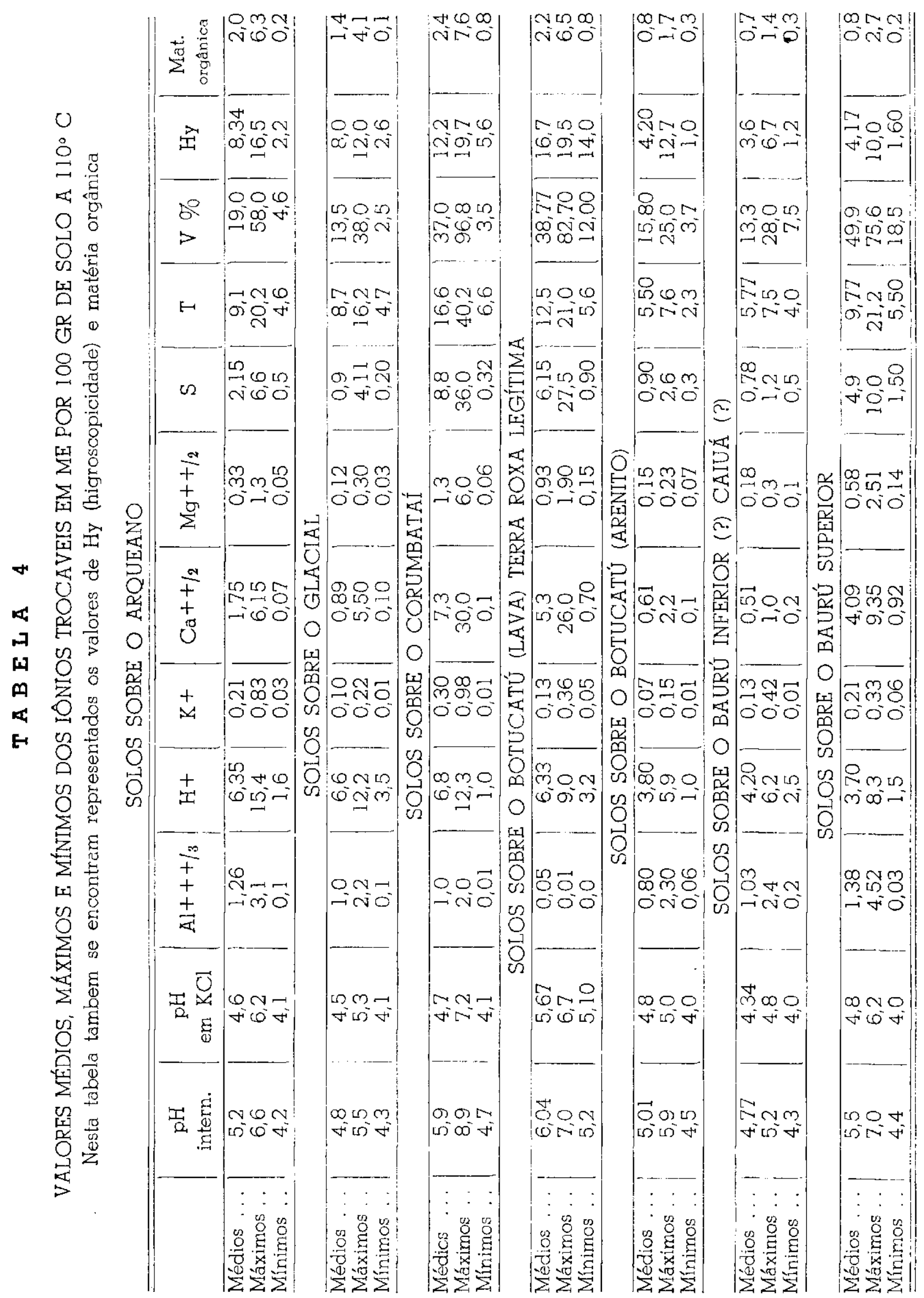


T A B E L A 5

FIXAÇÃO DE Ca++ NA TERRA ROXA LEGÍTIMA (DA ZONA DE RIBEIRÃO PRETO)

\begin{tabular}{|c|c|c|c|}
\hline N. ${ }^{\circ}$ dos perfís & $\begin{array}{l}\text { Profundidade dos } \\
\text { horizontes em } \mathrm{cm}\end{array}$ & $\begin{array}{l}\text { ME de } \mathrm{Ca}++/ 2 \\
\text { troc. por } 100 \mathrm{gr} \text { de } \\
\text { terra "in natura". }\end{array}$ & $\begin{array}{l}\mathrm{ME} \mathrm{DE} \mathrm{Ca++/2} \mathrm{fi-} \\
\text { xados por } 100 \mathrm{gr} \\
\text { de terra após perco- } \\
\text { lação por sol. de } \\
\left.\mathrm{NH}_{4} \mathrm{Cl} \mathrm{N} / 1^{*}\right)\end{array}$ \\
\hline $400 \mathrm{a}$ & $0-40$ & 26,5 & 26,3 \\
\hline$b$ & $40-100$ & 4,9 & 10,0 \\
\hline $\mathrm{c}$ & $100-150$ & 2,4 & 7,6 \\
\hline $\mathrm{d}$ & $150-230$ & 1,4 & 6,0 \\
\hline e & $230-330$ & 1,0 & 4,6 \\
\hline $401 \mathrm{a}$ & $0-30$ & 11,6 & 15,6 \\
\hline $\mathrm{b}$ & $30-120$ & 6,7 & 10,5 \\
\hline $\mathrm{C}$ & $120-180$ & 2,1 & 6,2 \\
\hline $\mathrm{d}$ & $180-250$ & 1,8 & 5,3 \\
\hline e & $250-300$ & 2,3 & 6,7 \\
\hline
\end{tabular}

*) a relação entre terra e solução é de 1:10.

bidos sobre uma chapa fotográfica que, depois de revelada, apresentava um conjunto de pontos formando elipsóides caraterísticos para cada tipo de rede cristalina. Este método não se generalizou devido à necessidade de se trabalhar com cristais grandes. Logo em seguida, apareceu o método de Debye-Scherrer e Hull, descrito, entre outros, por Endell (15), que, em vez de trabalhar com um único cristal de grandes dimensões, usava uma infinidade de pequenos cristais, colocados em um tubinho de vidro de cerca de $0,5 \mathrm{~mm}$ de diâmetro. Estes nada mais representavam do que o material em pó. Tambem, em lugar de manter o pó em tubinhos, podiam ser feitos bastõezinhos, comprimidos em cilindros de metal. Com este método o estudo sobre roentgenografia pode disseminar-se a tal ponto que, só na Alemanha, em 1939, existiam mais de 50 laboratórios trabalhando nesse sentido. Os estudos roentgenográficos da Secção de Agro-geologia datam de meados de 1936, quando foi contratado, pelo Governo do Estado, para exercer funções neste Instituto, o prof. Kurd Endell, do qual o autor foi assistente. Nesse tempo, estudamos 
exclusivamente a análise roentgenográfica qualitativa *), que será tratada a seguir.

\section{MATERIAL UTILIZADO PARA AS PESQUISAS ROENTGENOGRÁFICAS}

O material cuja rede cristalina deverá ser identificada é a fração argila que provem da análise mecânica total. Essa fração, de ordinário, é primeiramente estudada no estado em que provem da análise mecânica, ou seja, sem receber outro tratamento. Segundo se apresenta o problema, o material em questão pode sofrer alguns tratamentos, afim-de que se obtenha a eliminação de determinada parte que, às vezes, diticulta a análise roentgenográfica, bem como a transformação de parte ou de' todo o material. Surge mesmo, por vezes, a necessidade de recorrer-se a concentrações fracionadas do material argila para obterse o desejado. A fração argila, em geral, apresenta constituintes cristalinos e amorfos com relação ao comprimento de onda dos raios $\mathrm{X}$ por nós utilizados.

Dentre os do segundo grupo, a matéria orgânica e os óxidos hidratados de ferro são os que mais comumente se apresentam. A presença da matéria orgânica faz com que a chapa roentgenagráfica se torne, por vezes, muito enegrecida, sobretudo na região dos primeiros círculos ; essa circunstância em muitos dos casos prejudica a nitidez, a ponto de ser impossivel o estudo da mesma. Em tais casos, pode-se eliminar a matéria orgânica, oxidando-a com $\mathrm{H}_{2} \mathrm{O}_{2}$. Entretanto, os óxidos hidratados de ferro, quando em grande quantidade (acima de $15 \%$ de $\mathrm{Fe}_{2} \mathrm{O}_{3}$, fato comum nas terras roxas legítimas), podem perturbar, ainda mais do que a matéria orgânica, o estudo das chapas.

$O$ enegrecimento produzido por esses óxidos hidratados, cobre a chapa uniformemente, isto é, desde o centro até as últimas raias. Dessa forma se pode distinguir o enegrecimento devido à matéria orgânica do proveniente dos óxidos hidratados de ferro.

$\bigcirc \mathrm{Fe}_{2} \mathrm{O}_{3} \mathrm{nH}_{2} \mathrm{O}$ pode ser dissolvido de forma relativamente facil, pelo $\mathrm{HCl}$ (concentrações a estudar em cada caso) e separado por decantações sucessivas, até que a água de lavagem não apresente mais reação ácida contra o metil-orange.

*) Mais tarde, entretanto, em meados de 1938, fomos à Alemanha e dedicamos parte do tempo que lá permanecemos à análise roentgenográfica quantitativa nos laboratórios do Instituto de Química de Rostock, sob a orientação do prof. Ulrich Hoffmann. Desta parte nada diremos neste trabalho. 
Em algumas das roentgenografias, o material argila foi tratado com $\mathrm{HCl}$ para eliminar o $\mathrm{Fe}_{2} \mathrm{O}_{3} \mathrm{nH}_{2} \mathrm{O}$ e, às vezes, com $\circ \mathrm{Al}_{2} \mathrm{O}_{3} \mathrm{nH}_{2} \mathrm{O}$ a-fim-de ressaltar o material existente em quantidade pequena. Na maioria dos casos, tivemos por objetivo fazer sobressair a caolinita.

\section{MÉTODO DE ANÁLISE ROENTGENOGRÁFICA USADO NA SECÇÃO DE AGRO-GEOLOGIA}

O método empregado nesta Seç̧ão é, como já expusemos em traços gerais, o de Debye-Scherrer e Hull, o qual emprega o material em forma de pó, isto é, pulverizado. Os suportes para o material em pó consistem em tubinhos de Mark, com diâmetro de 0,5 mm. O material é pulverizado em um pequeno gral de ágata; em seguida, enchem-se os tubinhos até mais ou menos 1,0 a $1,5 \mathrm{~cm}$ de altura e fecham-se com a ajuda de pequena lâmpada de álcool ou pequeno bico de gás. A seguir são adaptados e centralizados na casseta do aparelho. O tempo de exposição das chapas aos raios $\mathrm{X}$ refratados pode variar entre 1 e 3 horas, isto conforme o material em estudo e a diferença de potencial empregado para alimentação da válvula.

As roentgenografias constantes do nosso trabalho foram, em sua maioria, expostas aos raios $\mathrm{X}$ refratados por espaço de 2 horas. O film utilizado foi o Lawe-Film-Agfa com emulsão nas duas faces.

\section{APARELHO PARA ESTUDOS DE ROENTGENOGRAFIA EMPREGADO NA SECÇÃO DE AGRO-GEOLOGIA}

O aparelho da Secção (15) é de marca "Siemens-Berlin", servido de válvula com anti-catódio de cobre. O filtro usado é o de niquel ou carbonato de niquel para interceptar as irradiações $\beta$ nocivas; a válvula emite, pois, unicamente irradiações $\operatorname{CuK} \alpha \operatorname{com} \lambda=1,539 \AA$.

O tubo trabalha com intensidade fixa de corrente de cerca de 13 m.A. e diferenças de potencial de $30.000,37.000$ e 45.000 voltes. A corrente de entrada é alternativa de 110 ou $220 \mathrm{v}$ e 60 períodos. A válvula é resfriada por meio de água que circula durante todo o tempo em que o aparelho trabalha. Podem ser tomadas, de uma só vez, três roentgenografias. $O$ diâmetro das cassetas compreende 57 milímetros. 


\section{AS REDES CRISTALINAS MAIS IMPORTANTES PARA NOSSOS PROBLEMAS}

A figura $2(a, b, c, d, e, f)$ nos dá idéia da arquitetura de um tetraedro de silício, octaedros de magnésio e de alumínio, assim como de sílica hidratada, alumínio hidratado e magnésia hidratada. A estrutura dos silicatos hidratados de alumínio representa as combinações das primeiras pedras fundamentais, mais ou menos hidratadas, umas com as outras. Assim, passamos a descrever rapidamente cada uma dessas principais estruturas.

Haloisita (figura 3-a) :

A rede cristalina desta argila é constituida por uma camada de sílica, completamente hidratada, situada sob uma outra de gibsita, em idêntico estado de hidratação. Esta estrutura não é muito estavel ; a $40^{\circ} \mathrm{C}$ já sofre um colapso em sua trama cristalina.

Caolinita (figura 3-b) :

A rede cristalina de caolinita é composta por uma camada de sílica juxtaposta a outra de gibsita levemente alterada.

\section{Montmorrilonita (figura 4-a) :}

A rede cristalina da montmorrilonita é composta de duas camadas de sílica schandwichando e uma de gibsita, ligadas entre si por átomos de oxigênio.

\section{Nontronita :}

A estrutura dessa argila é idêntica à da montmorrilonita, com a diferença de que os átomos de alumínio são aí substituidos por átomos de ferro.

\section{Talco (figura 4-b) :}

A estrutura desta rede é composta de duas camadas de sílica schandwichando e uma de brucita, ligadas entre si por meio de átomos de oxigênio. 


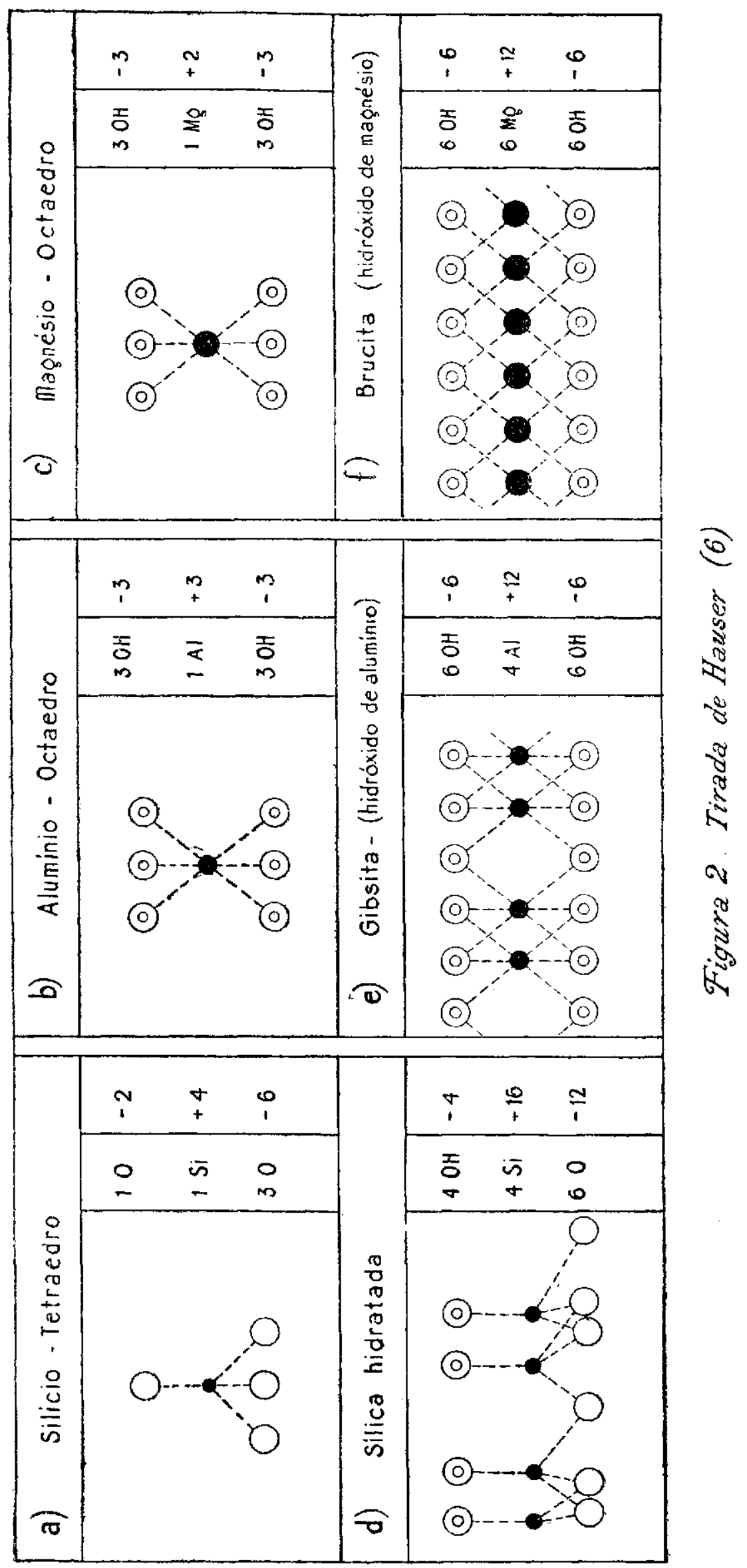




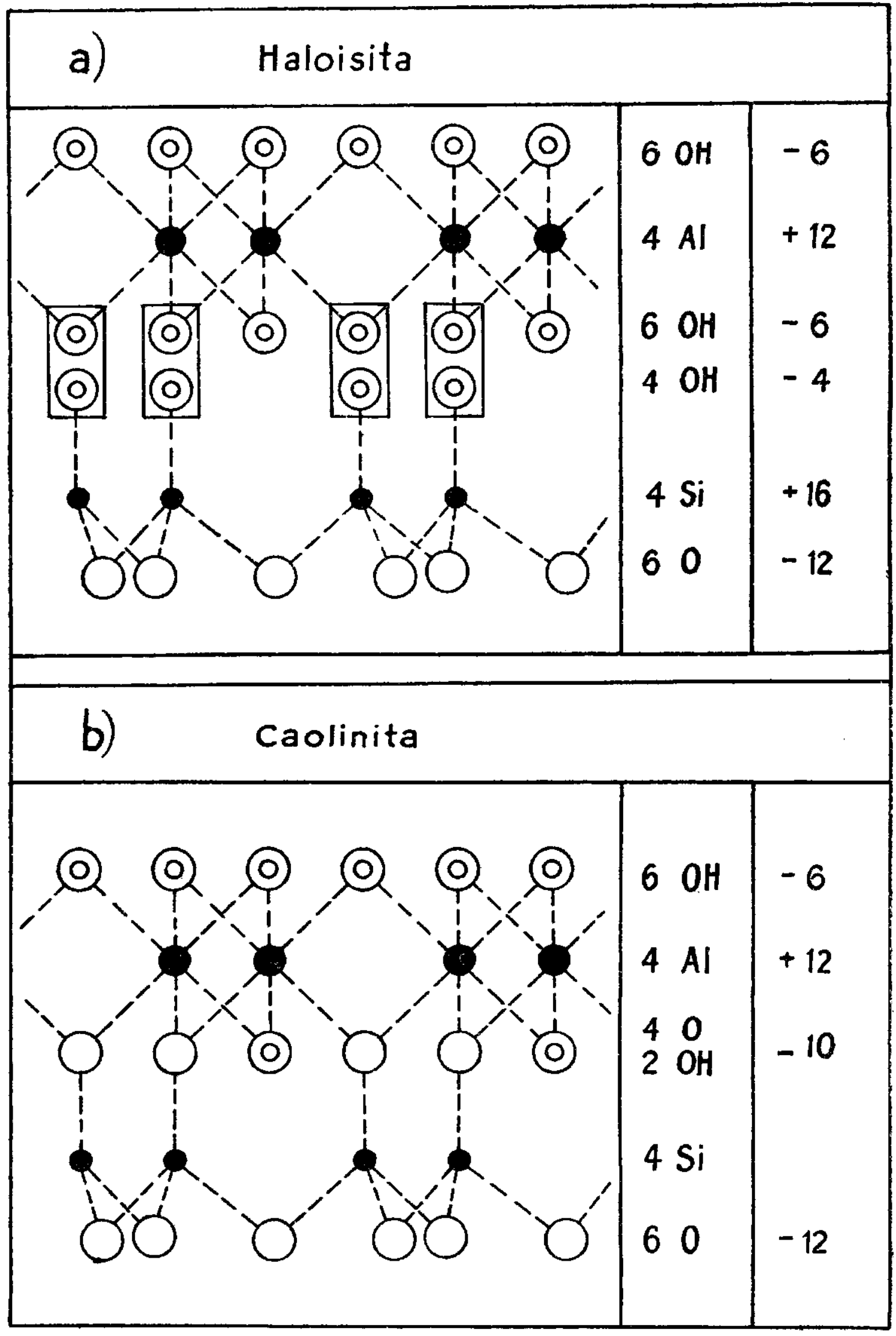

Figura 3 . Tirada de Hauser (6) 
a) Pirofilita e Montmorrilonita (caso ideal)

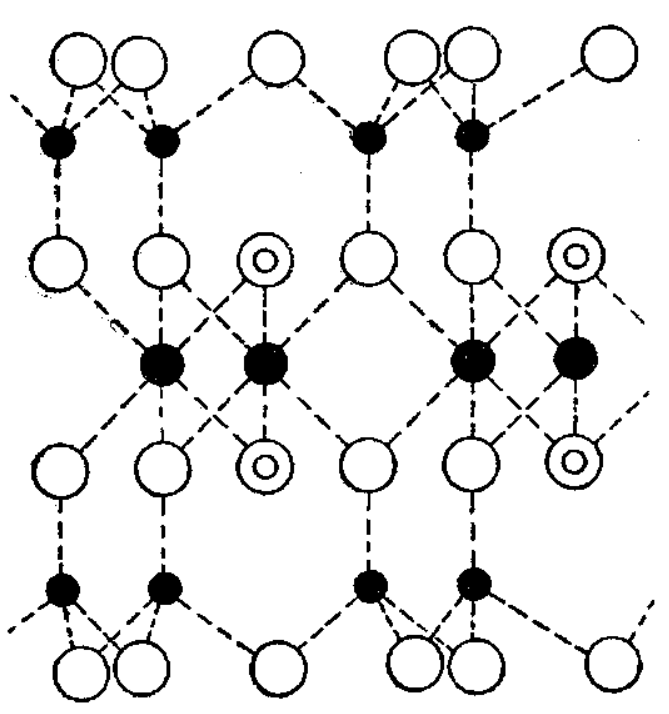

$\begin{array}{ll}6 & 0 \\ 4 & \mathrm{Si}\end{array}$

$-12$

$4 \mathrm{O}+2 \mathrm{OH} \quad-10$

$4 \mathrm{Al}$

$+12$

$4 \mathrm{O}+2 \mathrm{OH}$

$-10$

$4 \mathrm{Si}$

$+16$

60

$-12$
b)
Talco

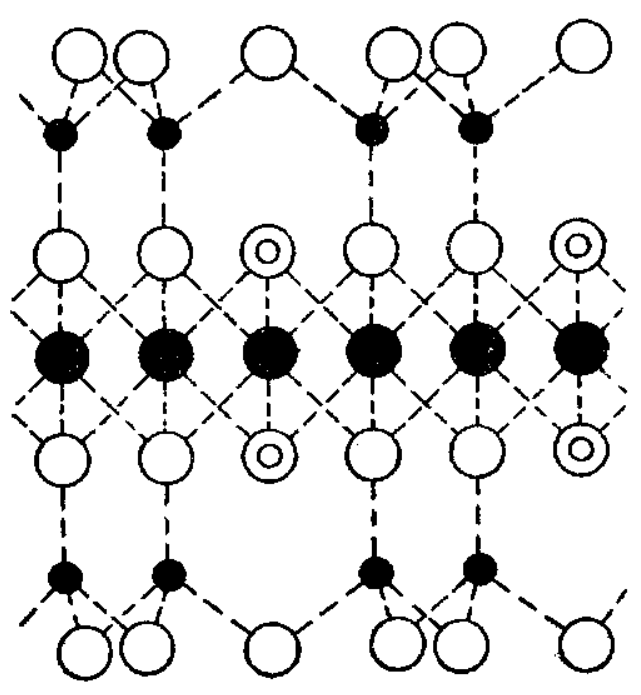

$\begin{array}{ll}6 & \mathrm{O} \\ 4 & \mathrm{Si}\end{array}$

$-12$

$+16$

$4 \mathrm{O}+2 \mathrm{OH}-10$

$6 \mathrm{Mg}$

$+12$

$4 \mathrm{O}+2 \mathrm{OH}$

$-10$

$4 \mathrm{Si}$

$+16$

60

$-12$

Fiqura 4. Tiradá de Hauser (6) 


\section{Ilita ou argila $\mathbf{X}$ :}

A estrutura da ilita é idêntica à da montmorrilonita, com a diferença de que pode ocasionar a substituição de certos átomos de sílica por átomos de alumínio e, então, obtemos um desequilíbrio de electrons. Este desequilíbrio gera nas camadas de sílica certa carga negativa, a qual fica, assim, neutralizada por meio de adsorção de um catiônio, o $\mathrm{K}^{+}$, por exemplo. Na figura 4-a podemos admitir a substituição do iônio Si pelo iônio $\mathrm{Al}$ da posição seguinte : na $1 .^{\text {a }}$ camada (tetraedros de $\mathrm{Si}$ ) substituir o $2 .^{\circ}$ iônio $\mathrm{Si}$ por um iônio $\mathrm{Al}$ (da esquerda à direita) e, na última camada (tetraedros de $\mathrm{Si}$ ), o 3. ${ }^{\circ}$ iônio Si por um iônio Al. Nesses pontos seriam adsorvidos 2 equivalentes do catiônio $\mathrm{K}^{+}$, como já dissemos. Esclarecimentos maiores, sobre as questões tratadas, podem ser obtidos consultando $(16,17,18,19,20,21)$.

\section{DISTÂNCIA EXISTENTE ENTRE OS PLANOS DA REDE CRISTALINA}

A maior ou menor distância livre entre os planos das redes cristalinas das argilas, tem grande importância nos fenômenos físico-químicos, em geral. A questão da troca de iônios é um dos mais importantes, não só do ponto de vista agro-geológico, como tambem cerâmico, rodoviário, de fundações, barragens, etc.

A distância livre, entre os planos das redes cristalinas das argilas do tipo caolinítico, é de $2,8 \AA$, enquanto que as do tipo montmorrilonítico é de $8,6 \AA$. A atração elétrica entre os planos das redes cristalinas decresce com o quadro da distância. É por essa razão que as argilas do grupo montmorrilonítico entumescem ou funcionam' como sanfonas, por uma simples hidratação ou deshidratação, a relativamente baixa temperatura. Esse fenômeno é tantas vezes reversivel, quantas se queiram, com a condição de que a temperatura não ultrapasse muito de $100^{\circ} \mathrm{C}$.

Essa grande distância entre os planos da rede cristalina contribue, consideravelmente, para aumentar a superfície ativa das partículas. Diz-se, mesmo, que estas argilas possuem tambem superfície interna, que é muito maior do que a externa. A média dos diâmetros dos iônios (excetuando-se $\circ$ iônio $\mathrm{H}^{+}$) encontra-se, em geral, acima de $2,8 \AA$ e, assim, não podem ficar adsorvidos entre os planos das redes cristalinas das argilas de tipo caolinita (pois não podem penetrar em fendas tão reduzidas). O poder sortivo das argilas montmorriloníticas pode atingir mais de $100 \mathrm{ME}$ de catiônios por $100 \mathrm{gr}$, enquanto que as do tipo caoliníticas não alcançam, de ordinário, $10 \mathrm{ME}(22,23,24,25)$. 


\section{RESULTADO DAS ANÁLISES ROENTGENOGRÁFICAS}

Damos, a seguir, uma série de 79 roentgenografias. Após cada série, em seguida à formação geológica de que provem, encontra-se um quadro contendo os seguintes dados: $1 .^{\mathrm{a}}$ coluna, número do perfil seguido da letra que especifica o horizonte edafológico; $2 .^{\mathrm{a}}$, número que vem impresso ao lado da chapa ; $3 .^{2}$, localização da amostra ; 4.", tratamento recebido pela argila antes de roentgenografada e $5 .{ }^{\mathbf{a}}$, análise roentgenográfica da argila, contendo, qualitativamente, os seus constituintes minerais.

\section{AMOSTRAS DOS SOLOS SITUADOS NO ARQUEANO}

Figura em primeiro lugar o estudo das amostras de solos massapés e salmourões que se assentam sobre $o$ arqueano.

Encontram-se representadas no quadro dezessete roentgenografias, as quais sempre evidenciam a caolinita e tambem a hidrargilita, embora com menor frequência. Em determinados casos, $\circ \mathrm{Al}_{2} \mathrm{O}_{3}$, em forma de hidrargilita pode alcançar $37 \%$ do $\mathrm{Al}_{2} \mathrm{O}_{3}$-total do complexo argila. Um exemplo desta ordem foi observado em uma argila procedente das proximidades de Caieiras, SPR.

Esse material é o das chapas 16 e 17. O primeiro representa material natural (fração argila) e o segundo, a mesma fração, porem tratada com $\mathrm{HCl}$ concentrado, a-fim-de eliminar grande parte dos óxidos hidratados de alumínio e ressaltar, assim, a caolinita. A fração argila dessa formação não é, comumente, rica em ferro, de modo que fornece boas chapas, a não ser que exista excesso em matéria orgânica.

\section{AMOSTRAS DOS SOLOS SITUADOS NO GLACIAL}

Nestas comumente se notam as mesmas oscilações e constituintes observados no arqueano. Não se distingue, com facilidade, uma formação da outra (Glacial e Arqueano) somente por meio da análise roentgenográfica. Em geral, a caolinita figura em quantidade elevada. Em determinados pontos do glacial, o complexo argila-humus se apresenta muito rico em óxidos hidratados de ferro, de modo a tornar, por vezes, necessária a sua remoção pelo $\mathrm{HCl}$, a-fim-de que os silicatos hidratados de alumínio possam sobressair nas chapas. Apresentamos, neste trabalho, 13 roentgenografias de amostra de solos situados no Glacial. 


\section{AMOSTRAS DOS SOLOS SITUADOS NO CORUMBATAf}

A fração argila dos solos desta tormação mostra, pelas roentgenografias, ser constituida em grande parte, e por vezes até na sua totalidade, de quarzo $\left(\mathrm{SiO}_{2}\right)$. A predominância do quarzo facilita, sobremaneira, a classificação desse tipo de solo. É o único no Estado que se apresenta com essas caraterísticas. Por vezes, nota-se a presença da caolinita, todavia, em percentagem reduzida. O teor em $\mathrm{Fe}_{2} \mathrm{O}_{3} \mathrm{nh}_{2} \mathrm{O}$ pode perturbar a nitidez das chapas. Esse inconveniente, como já dissemos, se remove com facilidade, tratando a argila com $\mathrm{HCl}$.

Este trabalho contem cinco chapas roentgenográficas ilustrando - material procedente da formação Corumbataí.

\section{AMOSTRAS DOS SOLOS SITUADOS NO BOTUCATÚ (Lava)}

Acham-se situados nesta formação geológica os solos de tipo terra roxa legítima. Procedem do magma diabásico. $O$ complexo argila-humus desse tipo de solo é muito rico em óxidos hidratados de ferro, os quais dificultam consideravelmente a obtenção de chapas nítidas. Não raras vezes, é impossivel o estudo das chapas obtidas de material sem tratamento tal o enegrecimento produzido pela difusão irregular dos raios $\mathrm{X}$. Esse empecilho, aliás, já discutimos em outra parte do presente trabalho. A hidrargilita e a caolinita são as partes do complexo argila-humus que se apresentam com retículo cristalino aos raios $\mathrm{X}$.

Em muitos casos, $85 \%$ do $\mathrm{Al}_{2} \mathrm{O}_{3}$ total do complexo se encontram em forma livre de $\mathrm{Al}_{2} \mathrm{O}_{3} \mathrm{nH}_{2} \mathrm{O}$. $\mathrm{O} \mathrm{Fe}_{2} \mathrm{O}_{3}$ chega a atingir $34,2 \%$ do complexo argila-humus a $110^{\circ} \mathrm{C}$, como pode ser observado na tabela 1 da análise química total do complexo. A quantidade de caolinita oscila entre 9,0 e $25 \%$ do complexo a $110^{\circ} \mathrm{C}$. Aquí, encontram-se 6 roentgenografias típicas do tipo de solo que acabamos de descrever.

\section{AMOSTRAS DOS SOLOS SITUADOS NO CAIUA (?) OU BAURÚ INFERIOR (?)}

Estes solos são essencialmente arenosos, como já ficou visto pelo gráfico da análise mecânica. A percentagem da fração argila é da ordem 9 a $15 \%$ de terra fina a $110^{\circ} \mathrm{C}$.

É interessante notar que a presença de hidrargilita na fração argila dos solos citados é mais ou menos persistente, sendo em alguns casos o principal constituinte. Como coparticipante da hidrargilita, figura a 
caolinita que, às vezes, avulta em percentagem. De ordinário, é reduzida a quantidade de óxidos hidratados de ferro, não dificultando, por conseguinte, a obtenção de chapas nítidas.

Comumente, a parte orgânica não interfere na nitidez das chapas. A formação que acabamos de estudar encontra-se representada por 15 chapas roentgenográficas.

\section{AMOSTRAS DOS SOLOS SITUADOS NA FORMAÇÃO GEOLÓGICA BAURÚ (SUPERIOR)}

É na fração argila dos solos situados na formação geológica Baurú Superior (arenito cinerítico) que são encontrados os minerais de argila, do tipo montmorrilonítico (26). Podemos constatar, pelas roentgenografias e quadros de análise das amostras em apreço, a presença, por várias vezes, desse tipo de argila. A caolinita e o quarzo tambem se encontram, com frequência, aí representados. $O$ complexo argila-humus, em geral, se apresenta com pequena percentagem de óxidos hidratados de ferro. Na chapa 76 verificamos a presença de ilita, argila de mica ou ainda a denominada argila X. A presença desta última pode ser considerada como acidental, porquanto nada existe que a justifique aí, devendo ser admitido, como origem, unicamente o transporte.

A presença da argila montmorrilonítica geralmente se evidencia, quando a amostra é colhida em local próximo ao arenito cinerítico, rocha-mater do solo em apreço. A título de ilustração, encontram-se neste trabalho 23 roentgenografias, representando o material em apreço.

Desse ligeiro traçádo sobre os constituintes dos minerais de argila que se encontram em nossos grandes tipos de solo, vemos que a variação é relativamente pequena quanto à quantidade. É grande, porem, quanto à percentagem de cada um dos seus constituintes. A caolinita, por exemplo, é a mais disseminada; é encontrada em quase todos os nossos solos. Em certos casos ela perfaz quase que a totalidade da fração argila (solos massapé ou salmourão) ; em outros casos ela contribue com pequena percentagem (terra roxa legítima). Outro constituinte que é frequentemente encontrado, é a hidrargilita ; as proporções tambem variam muito. Os óxidos hidratados de ferro no tipo terra roxa legítima chega a perfazer, na forma de $\mathrm{Fe}_{2} \mathrm{O}_{3}, 35 \%$ de terra fina seca a $110^{\circ}$.

Em certas manchas de solos situados no Glacial, a quantidade de $\mathrm{Fe}_{2} \mathrm{O}_{3}$ tambem avulta; encontra-se bem disseminada, porem em proporções menores, em vários outros tipos de solo. 
$O$ quarzo e o tipo montmorrilonítico são os que se mostram com menor frequência. A ilita ou argila $\mathrm{X}$, conquanto raramente, tambem aparece em solos procedentes, sobretudo, de restos de micaxistos.

Assim, os principais constituintes dos minerais de argilas, na ordem decrescente, são os seguintes: caolinita, óxidos hidratados de ferro e alumínio (hidrargilita), quarzo, tipo montmorrilonítico e ilita.

Infelizmente, os solos deste tipo são essencialmente arenosos e conteem pequena percentagem do mineral.

Em grande parte, o poder sortivo de nossos solos deve ser atribuido essencialmente à matéria orgânica, ou ligações desta com os óxidos hidratados de ferro, alumínio e sílica.

Na terra roxa legítima, os óxidos hidratados de ferro e alumínio, pelo alto grau de dispersão em que se encontram, contribuem, para o poder sortivo, com aproximadamente 3 a $6 \mathrm{ME}$ de catiônios por $100 \mathrm{gr}$ de solo.

\section{RESUMO E CONCLUSÕES}

Iniciamos o presente trabalho dando uma rápida idéia sobre o que se entende pelo termo "argila", os métodos científicos aplicados ao estudo desse material e sua concepção com referência aos estudos edafológicos. Descrevemos os métodos de análise mecânica total e natural, que adotamos na Secção de Agro-geologia.

O trabalho é ilustrado por um gráfico mostrando as frações da análise mecânica dos principais grandes tipos de solo do Estado de São Paulo.

A fração argila é em seguida estudada quimicamente, na seguinte ordem: $10^{\circ}$, análise química total, $2 .^{\circ}$, análise química parcial, $3 .^{\circ}$, análise química da camada de Helmholz e $44^{\circ}$, estudo da fixação do iônio Ca++ na já citada camada de Helmholz.

A primeira análise desintegra e ataca os silicatos hidratados de alumínio, os óxidos hidratados de ferro e alumínio, manganês, etc. Nessa análise determinamos as relações entre sílica e sesquióxidos.

- O segundo tipo de ataque ou análise química não toca nos silicatos hidratados de alumínio; os demais passam em solução. Nessa análise determinamos principalmente os sesquióxidos na forma livre no complexo argila. Para o estudo da camada de Helmholz, isto é, determinação dos 1ônios trocaveis, usamos solutos de $\mathrm{NH}_{4} \mathrm{Cl} \mathrm{N} / 1, \mathrm{HNO}_{3} \mathrm{~N} / 5, \mathrm{KCl} \mathrm{N} / 1$ etc., fazendo esses líquidos percolarem através de uma camada de terra 
seca ao ar. A relação entre terra e líquido foi sempre de 1:10. Nessa análise determinamos essencialmente os catiônios $\mathrm{K}^{+}, \mathrm{Ca}^{++}, \mathrm{Mg}^{++}$, $\mathrm{Al}+++, \mathrm{H}^{+}$, etc. Com tais determinações calculamos os valores seguintes: $\mathrm{S}=$ soma das bases trocaveis em $\mathrm{ME} ; \mathrm{T}=$ valor total em ME do poder sortivo do complexo por $100 \mathrm{gr}$ de terra seca a $110^{\circ} \mathrm{C}$ e $\mathrm{V}=$ percentagem de saturação dos complexos em bases.

Finalmente, procedemos à análise roentgenográfica qualitativa da fração argila pelo método de Debye-Scherrer-Hull. Para esses estudos usamos o aparelho da "Siemens-Berlin", cujo transformador trabalha com corrente alternada de $110-220 \mathrm{~V}$ e 60 ciclos. A válvula possue anti-catódio de cobre e é alimentada com corrente de intensidade de 13 m.A. e a diferença de potencial é de $30.000,35.000$ e 47.000 voltes. $\mathrm{O}$ jato de raios $\mathrm{X}$ passa pelo filtro de niquel para livrá-lo das irradiações $\beta$ nocivas e assim temos, incidindo verticalmente sobre a preparação, radiações $\mathrm{CuK} \alpha \operatorname{com} \lambda=1,539 \AA$ A. A película 'sensivel usada foi a de Lawe-Film-Agfa, com tempo de exposição entre 1 1/2 e 2 horas com $35.000 \mathrm{~V}$. A casseta tem o diâmetro de $57 \mathrm{~mm}$. Tiramos mais de 500 roentgenografias de amostras de solos situados em todo o Estado, 79 das quais apresentamos no presente trabalho. Com esse material conheceram-se os vários constituintes dos minerais de argila existentes em nossos solos. Assim, nos solos sobre a formação geológica arqueana, a caolinita é o representante mais assíduo e forte ; a hidrargilita tambem. aparece comumente. Nos solos sobre o glacial temos os mesmos representantes e oscilações que no arqueano. Na formação Corumbataĺ é o quarzo o principal constituinte.

A formação Botucatú (Lava) é a que deu origem aos nossos solos de terra roxa legítima; os constituintes mineralógicos de argila destes são: $1 .^{\circ}$, grande quantidade de óxidos hidratados de ferro até $35 \%$ de $\mathrm{Fe}_{2} \mathrm{O}_{3}$ por $100 \mathrm{gr}$ de terra a $110^{\circ} \mathrm{C} ; 2^{\circ} .^{\circ}$, hidrargilita e 3. ${ }^{\circ}$, caolinita. A quantidade desta última no complexo argila oscila entre 9 e 25\%. Os solos arenosos situados nas formações geológicas Baurú inferior e Baurú superior trazem em suas argilas os seguintes constituintes mineralógicos : $1 .^{\circ}$, caolinita, 2..$^{\circ}$ tipo montmorrilonítico (só no Baurú superior), 3. ${ }^{\circ}$, hidrargilita (mais comum no Baurú inferior) e $4 .^{\circ}$, quarzo, em geral, em pequenas percentagens. Por essas pesquisas ficou patente que, comumente, os constituintes da fração argila de nossos solos possuem pequeno poder sortivo para com os catiônios ; disso resulta não apresentarem grande poder para retenção dos adubos, com exceção do tipo montmorrilonítico. 


\section{S U M M A R Y}

In the beginning of this work a brief idea was given on what is understood as "clay", on the scientific methods applied to the study of the matter "clay" as well as on its conception with regard to the edaphic studies. A description is given of the methods of total and natural mechanical analyses which were employed in the agro-geological Department.

The work is illustrated by a graphic showing the fractions of the mechanical analysis of the chief great soil types of the State of São Paulo.

The fraction clay is then studied by chemical way in the following sequence: 1." total chemical analysis, $2 .^{\circ}$ partial chemical analysis, $3 .{ }^{\circ}$ chemical analysis of the Helmholz layer and $4 .^{\circ}$ study of the fixation of the ion $\mathrm{Ca}++$ in the already mentioned Helmholz layer.

The first analysis separates and attacks the hydrated aluminium silicates, the hydrated oxyds of iron and aluminium, manganese, etc. In this analysis the relationship between silica and sesquioxyds was determined.

The second type of attack or chemical analysis does not affect the hydrated silicates of aluminium, all others go in dissolution. In this analysis were determined chiefly the sesquioxyds in their free form in the clay complex. For the study of the Helmholz layer, i.e. the determination of changeable ions, solutes of $\mathrm{NH}_{4} \mathrm{Cl} \mathrm{N} / 1, \mathrm{HNO}_{3} \mathrm{~N} / 5, \mathrm{KCl} \mathrm{N} / 1$, etc. were used, percolation of these liquids being made through a layer of air dried soil. The relationship between soil and liquid was always 1:10. In this analysis, principally the cations $\mathrm{K}+, \mathrm{Ca}++, \mathrm{Mg}++, \mathrm{Al}+++, \mathrm{H}+$ etc. were determined. With such determinations the calculations of the following values were obtained: $S=$ sum of the changeable bases in $\mathrm{ME} ; \mathrm{T}=$ total value in $\mathrm{ME}$ of the sorptive power of the complex in each $100 \mathrm{~g}$ dried soil at $110^{\circ} \mathrm{C}$. and $\mathrm{V}=$ percentage of saturation of the complexes with bases.

Finally, the qualitative radiographic analysis of the fraction clay was carried out by means of the Debye-Scherrer-Hull method. For these studies the Siemens-Berlin apparatus was used, the transformer of which runs with a 110-220 volts 60-cycle alternating current. The bulb has a copper anti-cathode and is fed by a current of $13 \mathrm{~m}$. $A$. of intensity and the difference of potential is of $30,000,35,000$ and 47,000 volts. The flash of X-rays goes through the nickel filter in order to free it of the $\beta$ irradiations which are deleterious. In this way, inciding vertically on the preparation, radiations $\mathrm{CuK} \alpha$ with $\lambda=1,539 \AA$ are obtained. The sensible film used was a Lawe-Film-Agfa, with an exposure going from $11 / 2$ to 2 hours with $35,000 \mathrm{~V}$. The chassis has a diameter of $57 \mathrm{~mm}$. More than 500 radiographs of soil samples were taken, of those proceding from all districts of the State, 79 of which are presented in the present work. With this material the different constituents of the clay minerals contained in our soils were known. Thus, in the soils over the Archean geological formation, kaolinite is represented most frequently and abundantly; the hydrargillite also appears commonly. The soils over the Glacial formation contain the same representatives and oscillations as those just mentioned. In the Corumbatal formation, quartz is the most important constituent.

The Botucatú formation (lava) is that which gave origin to our legitimate red soils; the mineralogical clay constituents of these soils are: 1.0 large amount of hydrated oxyds of iron up to $35 \%$ of $\mathrm{Fe}_{2} \mathrm{O}_{3}$ for each $100 \mathrm{~g}$ of soil at $110^{\circ} \mathrm{C}$; $2 .^{\circ}$ hydrargillite and 3.० kaolinite. The amount of the latter in the clay complex ranges between 9 and 25\%. The sandy soils existing in the geological formations of lower and upper Bauru bear in their clays the following mineralogical constituents: $1 .^{\circ}$ kaolinite, $2 .^{\circ}$ montmorrillonitic type (on the upper Baurú only), 3.' hydrargillite (more common on the lower Baurú) and $4 .^{\circ}$ quartz, generally, in small percentages. These researches made it evident that the constituents of the clay fraction of our soils commonly have a small sorptive power related to the cations; it follows hence that they do not show a great power of retention of manure with the exception of the montmorrillonitic type. 


\section{LITERATURA CITADA}

1. Wiegener, G. - Em Boden und Bodenbildung, 3.a edição, pg. 1-98, fig. 1-10, Von Theodor Steinkopff. Dresden e Leipzig, 1924.

2. Zsigmondy, R. - Em Coloidequímica, pg. 9-184. Traduzido do alemão para o espanhol por E. Moles. "Calpe" - Madrid - Barcelona, 1927.

3. Friedrich-Vincenz v. H. - Em Dispersoidanalyse, pg. 1-36, fig. 1-165, tab. 1-110, Von Theodor Steinkopff. Dresden e Leipzig, 1928.

4. Kruyt, H. R. - Em Les Colloides - pg, 3-203. Traduzido do francês, para o inglês por J. Du Plessis de Grenédan. Felix Alcan - Paris, 1933.

5. Van Buzágh, A. - Em Kolloidik pg. 1-174, fig. 1-68, tab. 1-18. Von Theodor Steinkopff. Dresden e Leipzig, 1936.

6. Hauser, E. A. - Colloid chemistry in Ceramic - The Journal and Ceramic Abstracts 24:179-189, fg. 1-15, tab. 1-3, 1941.

7. Paiva Neto - Percolação ou agitação na química dos complexos sortivos do solo. Bragantia 2:93-99, fig. 1-X-3, 1942.

8. Vageler, P. - Em Der Kationen-und Wasserhaushalt des Mineralbodens, pg. 40-83, fig. 1-34, Julius Springer, Berlin, 1932.

9. Renold, A. - Kationenaustausch an Permutiten, insbesondere an Wasserstoff und Schwermetallpermutiten, Kolloid-Beihefte, 43:1-142, fig. 1-9, 1935.

10. Cernescu, N. C. - Kationenumtausch und Struktur. Anuarul Institutulin Geologic al Romcinei M. O. Imprimeria Nationalã Bukarest 1931:1-89, 1933.

11. Lavolloy, J. - Em Le Magnesium dans les terres arables, pg. 101, Hermann \& Cia., Paris, 1936.

12. Blanck, E. $-E_{m}$ Handbuch der Bodenlehre, vol. VIII : 1-714. Verlag von Julius Springer, Berlin, 1930.

13. Schachtschabel, P. - Untersuchungen uber die Sorption der Tonmineralien und anorganischen Bodenkolloide und die Bestimmung des Anteils dieser Kolloide an der Sorption im Boden, Kolloid. Beihefte 51:199-276, pg. 1-12, 1940.

14. Hauser, E. A. - Em Colloidal Phenomena, pg. 1-294, fg. 1-123, McGraw-Hill Book Company Inc. New York e Londres, 1939.

15. Endell, K. - Pesquisa radioscópica de argilas e sua importância técnico-econômica. Bol. Téc., Inst. Agr. do Estado de S. Paulo, 31:25-40.

16. Bragg, W. L. - Em The Structure of Silicates, pg. 1-78, fg. 1-27, Akademische Verlagsgesellschaft M. B. H. - Leipzig, 1932.

17. Hofmann, U., - K. Endell, und W. Bilke, - Die Quellung von Bentonit und seine Technische Anwendung - Zeitschrift fur Elektrochemie $41: 469-471$, 1935.

18. Maegdefrau, E., U. Hofmann, - Glimmerartige Mineralien als Tonsubstanzen. Z. Kristallogr. (A). 98:31-59, 1937.

19. Brandley, W. F., R. E. Grimm, and G. L. Clark, - A Study of the Behavior of Montmorrilonite upon Wetting. - Z. Kristallogr. (A) 97:216-222, 1937.

20. Grim, R. E., R. H. Bray, and W. F. Brandley, - The Mica in Argilaceous Sediments. The American Mineralogist 22:813-829, 1937. 
21. Grim, R. E. and R. H. Bray, - The mineral constitution of various ceramic clays. - Journal of the American Ceramic Society 19:308-315, 1936.

22. Endell, K. und P. Vageler, - Der Kationen- und Wasserhaushalt Keramischer Tone in rohen Zustand Berichte der Deutschen Keramischen Gesellschaft $13: 377-411,1932$.

23. Endell, K., H. Fendius, und U. Hofmann, - Basenaustauschfaehigkeit von Tonen und Formgebungsprobleme in der Keramik Berichte der Deutschen Keramischen Gesellschaft. 15:595-625, 1934.

24. Grim, R. E., R. H. Bray, and W. F. Brandley, - The constitution of Bond Clays and Its Influence on Bonding Properties, Trans. Amer. Foundreymen's Assoc. VII : $211-228,1936$.

25. Ekblaw, G. E. and R. E. Grim, - Some geological relations between the constitution of soil materials and Highway construction. Report of investigations, n. 42 , pg. 5-16, fig. 1-4, Division of State Geological Survey, Urbana. Illinois. 1936.

26. Paiva Neto, J. E. de - Argilas do tipo montmorrilonítico nos solos do Estado de São Paulo. Mineração e Metalurgia. VI:87 - fig. 1-4. 1941. 


\title{
Formação geológica
}

\author{
ARQUEANA
}


ANALISE ROENTGENOGRÁFICA DA FRAÇÃO ARGILA DE PERFÍS SITUADOS NA FORMAÇÃO GEOLÓGICA $A R Q U E A N^{*} A$

\begin{tabular}{|c|c|c|c|c|}
\hline $\begin{array}{l}\text { N. }{ }^{\circ} \text { dos } \\
\text { perfís }\end{array}$ & $\begin{array}{l}\text { N. }{ }^{\circ} \text { das } \\
\text { chapas }\end{array}$ & $\begin{array}{c}\text { LOCALIZACAO } \\
\text { DOS } \\
\text { PERFÍS DE SOLO } \\
\end{array}$ & $\begin{array}{l}\text { TRATAMENTO } \\
\text { RECEBIDO } \\
\text { PELA ARGILA }\end{array}$ & $\begin{array}{c}\text { ANALISE } \\
\text { ROENTGENOGRAFICA } \\
\text { QUALITATIVA }\end{array}$ \\
\hline $3 c$ & 1 & $\begin{array}{l}\text { São Rogue - Faz. } \\
\text { Mairinque }\end{array}$ & $\begin{array}{l}\text { tratado com } \mathrm{HCl} \\
\text { concentrado para } \\
\text { separação dos óxi- } \\
\text { dos hidratados de } \\
\text { ferro }\end{array}$ & $\begin{array}{l}\text { caolinita }+ \text { hidrargilita } \\
+\mathrm{SiO}_{2} \text { (quarzo) pouco }\end{array}$ \\
\hline $4 c$ & 2 & $\begin{array}{l}\text { São Roque - Bairro do } \\
\text { Setubal }\end{array}$ & idem & essencialmente caolinita \\
\hline $52 a$ & 3 & $\begin{array}{l}\text { Caldas, E. Minas Ge- } \\
\text { rais, Quinta Formosa }\end{array}$ & nenhum & $\begin{array}{l}\text { muita hidrargilita }+ \text { cao- } \\
\text { linita }+\mathrm{Fe}_{2} \mathrm{O}_{3} \mathrm{nH}_{2} \mathrm{O}\end{array}$ \\
\hline $52 b$ & 4 & Idem, porem horizonte $b$ & " & idem \\
\hline $58 a$ & 5 & Campinas, Faz. Santana & $"$ & $\underset{\text { (pouca) }}{\text { caolinita }}+$ hidrargilita \\
\hline $58 b$ & 6 & Idem, porem horizonte $b$ & " & idem \\
\hline $134 \mathrm{c}$ & 7 & $\begin{array}{l}\text { Campinas, Faz. Sacra- } \\
\text { mento, próximo a Va- } \\
\text { linhos }\end{array}$ & " & $\underset{\text { (pouquíssima) }}{\text { caolinita }+ \text { hidrargilita }}$ \\
\hline $134 b$ & 8 & Idem, porem horizonte b & , & idem \\
\hline $174 a$ & 9 & Próximo a Cotia & 。 & $\underset{\text { (pouca) }}{\text { caolinita }}+$ hidrargilita \\
\hline $174 \mathrm{~b}$ & 10 & Idem, porem horizonte $b$ & " & idem \\
\hline $174 \mathrm{c}$ & 11 & Idem, porem horizonte $\mathrm{c}$ & " & $"$ \\
\hline $186 a$ & 12 & $\begin{array}{l}12 \mathrm{~km} \text { de Piedade a } \\
\text { Pilar }\end{array}$ & "r & muita $\begin{array}{l}\text { hidrargilita } \\
\text { caolinita }\end{array}+$ \\
\hline $186 \mathrm{~b}$ & 13 & Idem, porem horizonte $b$ & r & idem \\
\hline $186 \mathrm{c}$ & 14 & Idem, porem horizonte $c$ & " & " \\
\hline $253 c$ & 15 & $\begin{array}{l}\text { São Bernardo - Es- } \\
\text { tação Mauá }\end{array}$ & “ & caolinita + hidrargilita \\
\hline 一 & 16 & $\begin{array}{l}\text { próximo a Caieiras، } \\
\text { S. P. R. }\end{array}$ & " & hidrargilita + caolinita \\
\hline - & 17 & & $\begin{array}{l}\text { tratado com } \mathrm{HCl} \\
\text { concentrado }\end{array}$ & $\begin{array}{c}\text { caolinita }+ \text { hidrargilita } \\
\text { (pouca) }\end{array}$ \\
\hline
\end{tabular}



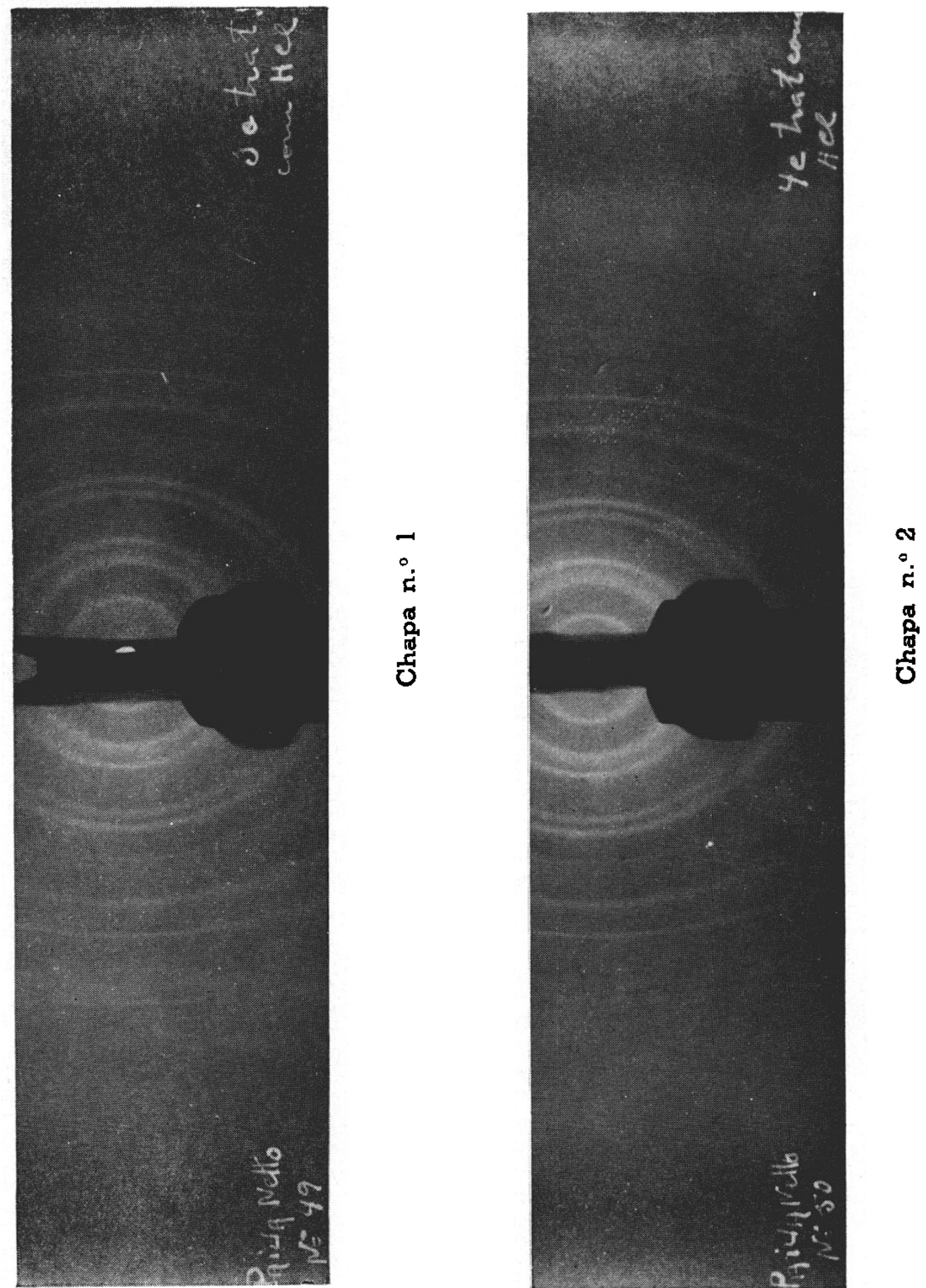

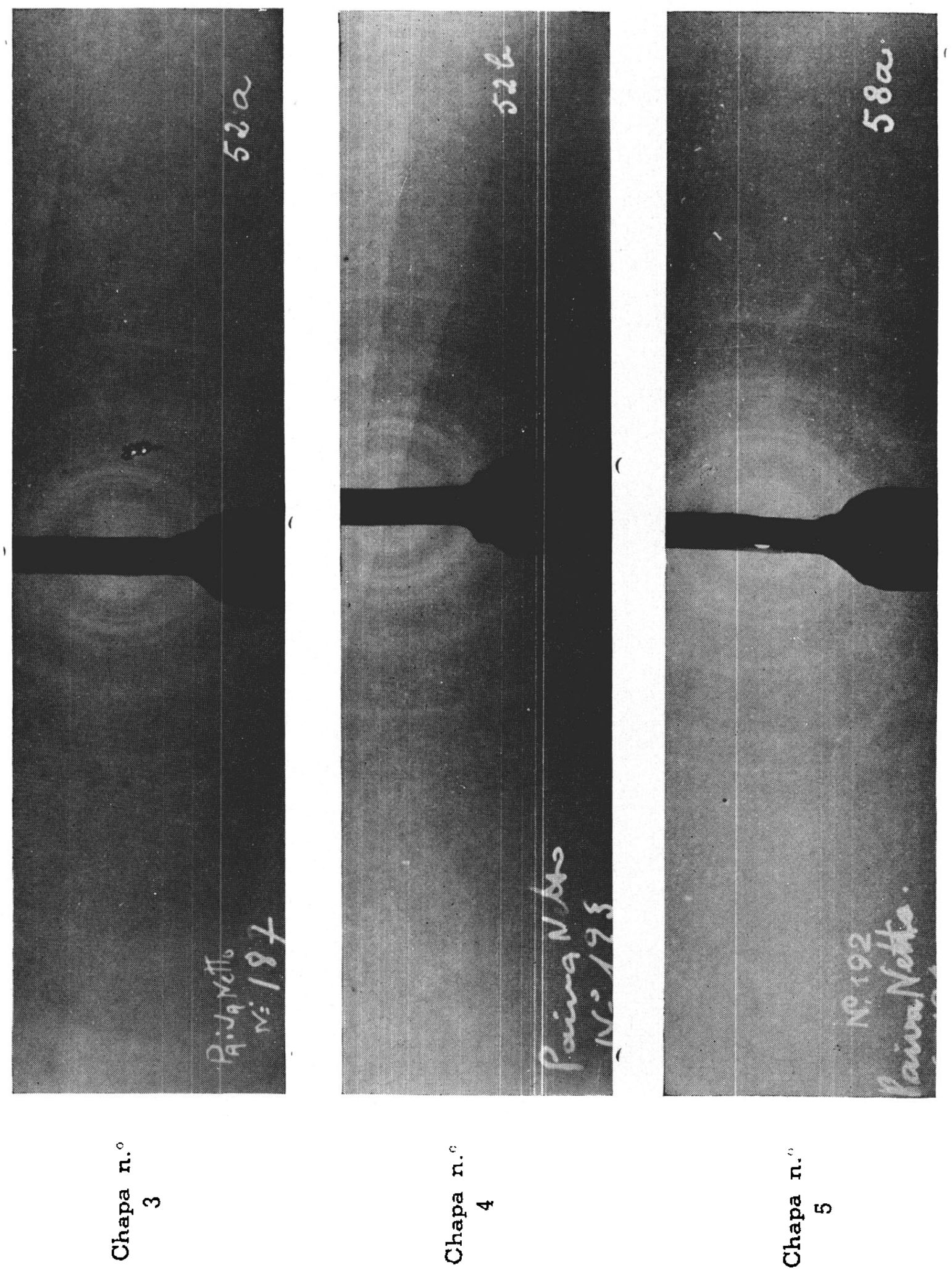


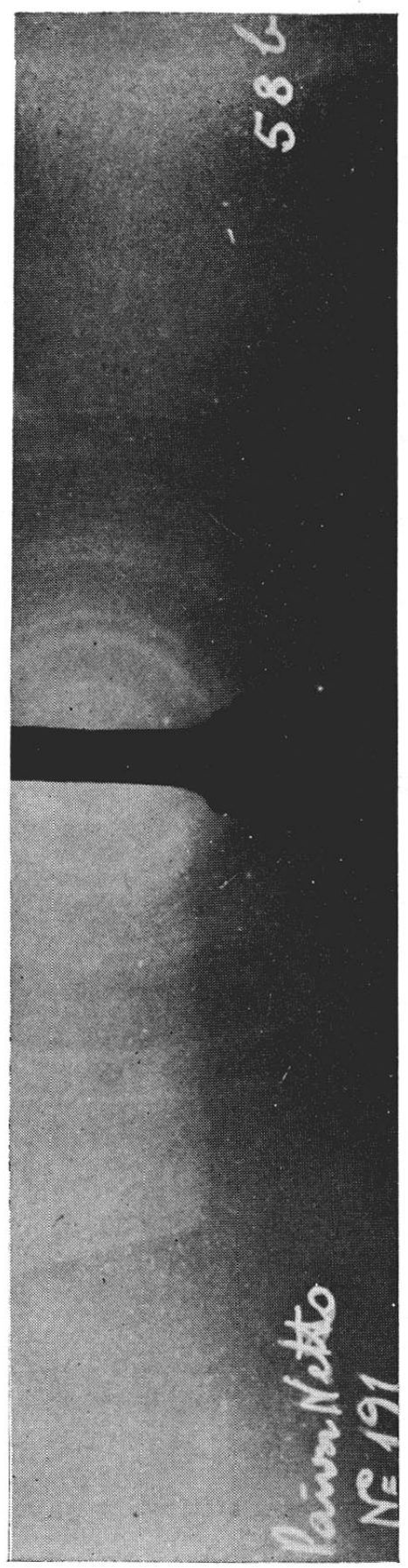

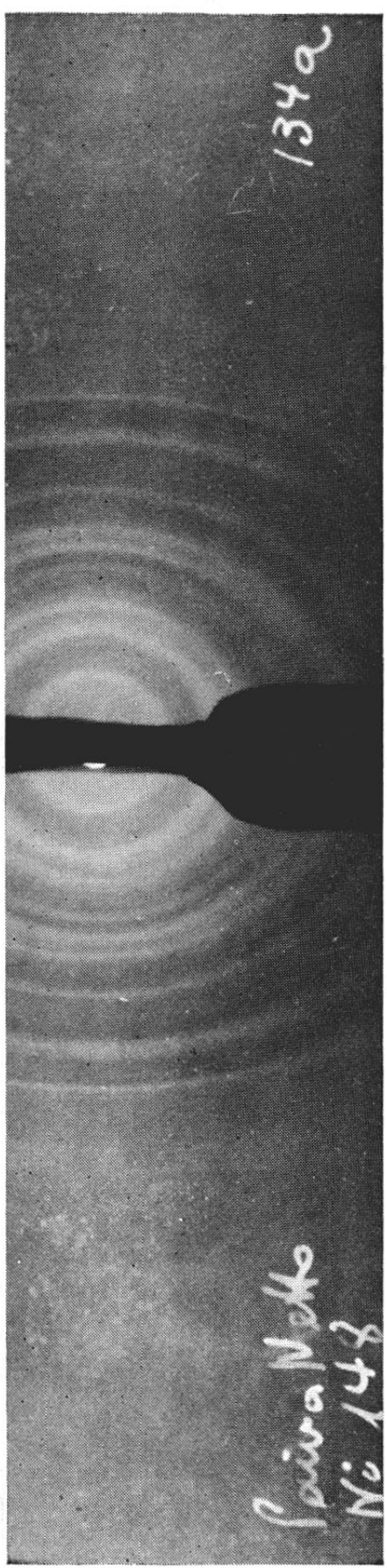

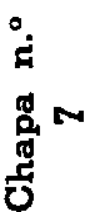

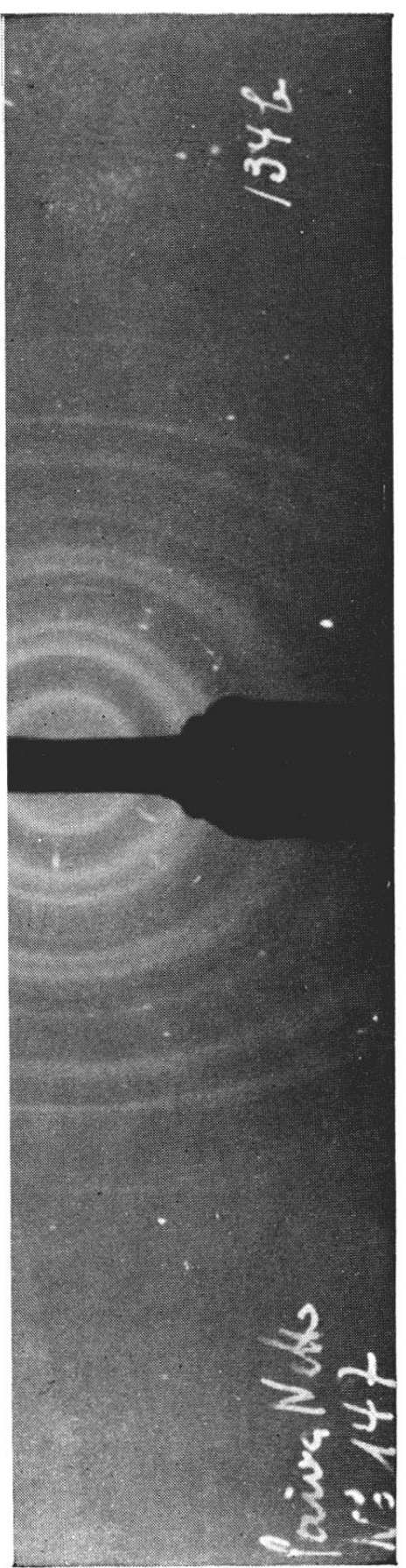

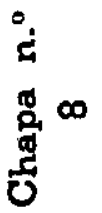


Tol. 2
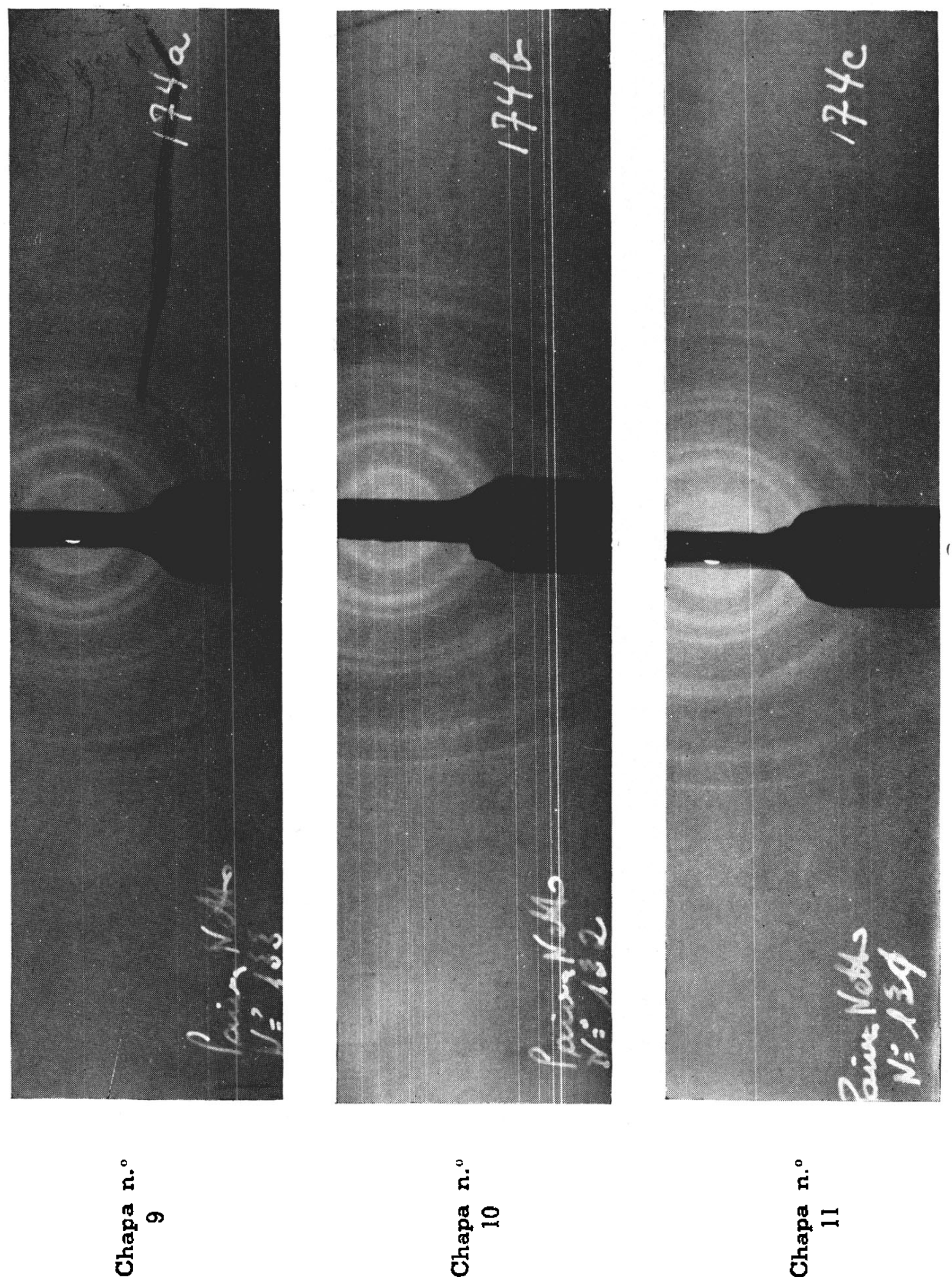

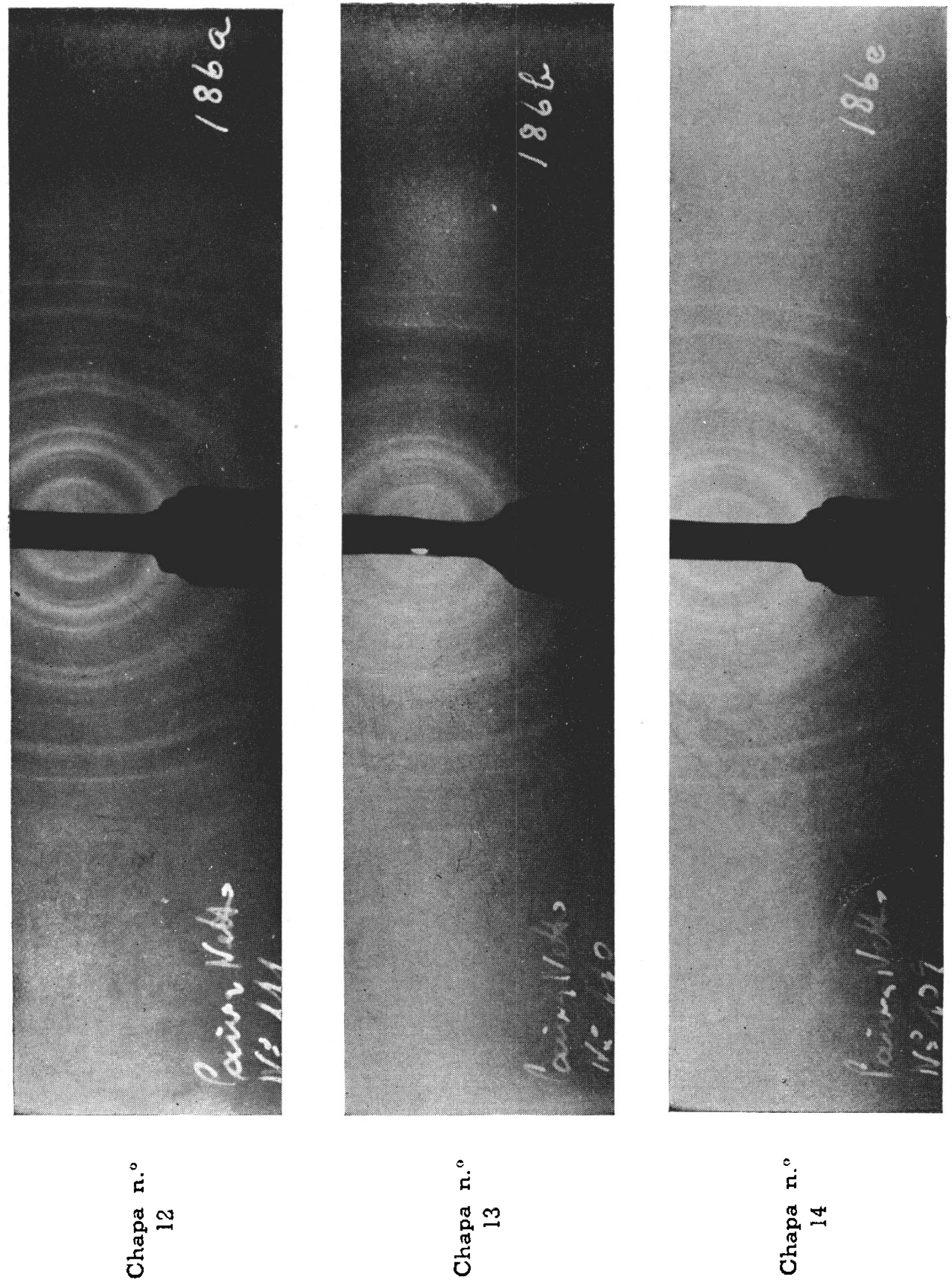

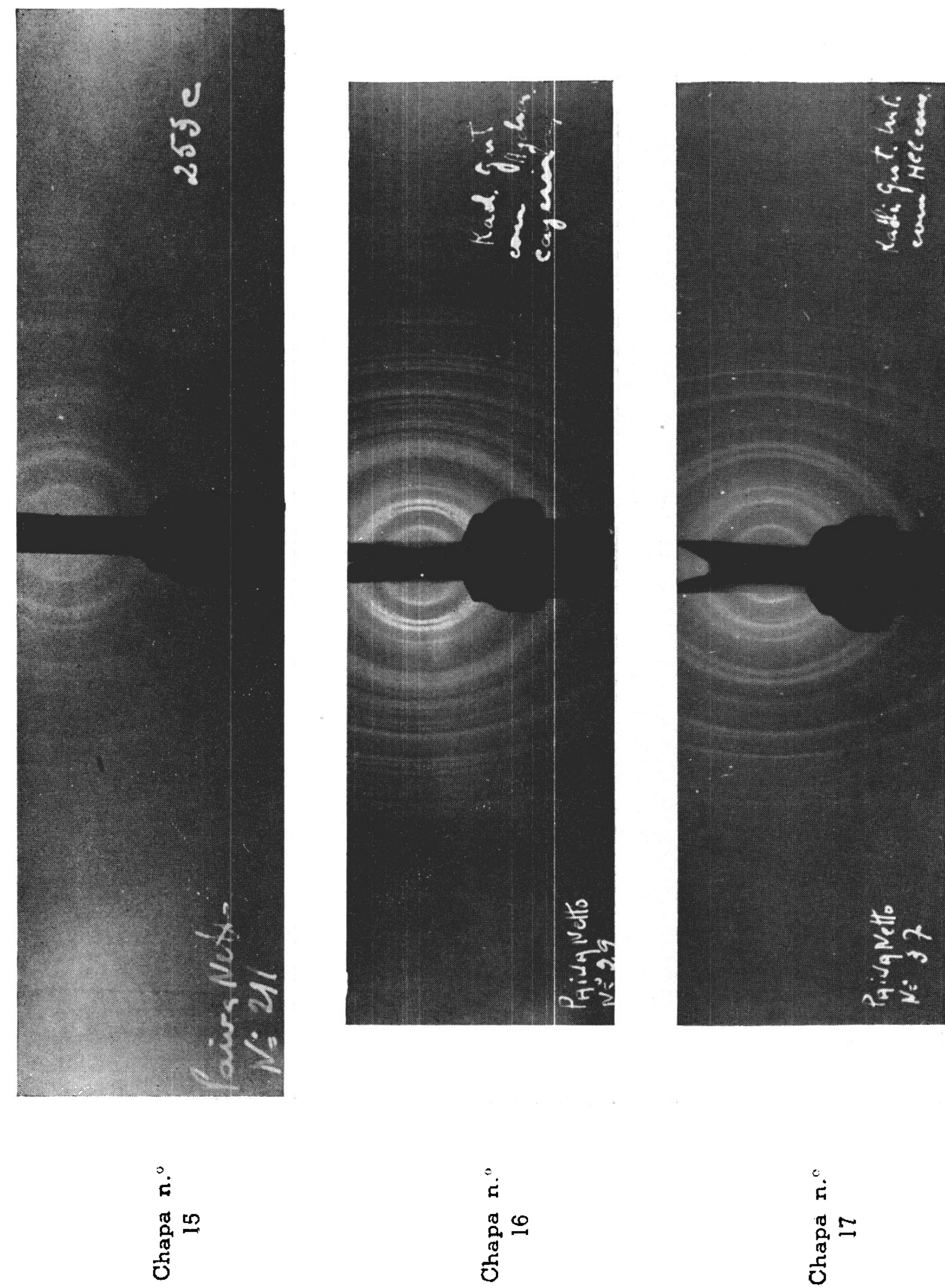
Formação geológica GLACIAL 
ANÁLISE ROENTGENOGRÁFICA DA FRAÇÃO ARGILA DE PERFIS SITUADOS NA FORMAÇÃO GEOLÓGICA G L A C I A L

\begin{tabular}{|c|c|c|c|c|}
\hline $\begin{array}{l}\text { N.o dos } \\
\text { perfís }\end{array}$ & $\begin{array}{l}\text { N. }{ }^{\circ} \text { das } \\
\text { chapas }\end{array}$ & $\begin{array}{c}\text { LOCALIZACAO } \\
\text { DOS } \\
\text { PERFIS DE SOLO }\end{array}$ & $\begin{array}{l}\text { TRATAMENTO } \\
\text { RECEBIDO } \\
\text { PELA ARGILA }\end{array}$ & $\begin{array}{c}\text { ANÁLISE } \\
\text { ROENTGENOGRAFICA } \\
\text { QUALITATIVA }\end{array}$ \\
\hline $2 b$ & 18 & $\begin{array}{l}\text { Campinas, amostra co- } \\
\text { lhida nos terrenos de } \\
\text { horticultura na Sede do } \\
\text { Instituto Agronômico }\end{array}$ & nenhum & caolinita + hidrargilita \\
\hline $135 a$ & 19 & $\begin{array}{l}\text { Campinas, saída da } \\
\text { cidade na direção de Itú }\end{array}$ & idem & $\underset{\text { (pouca) }}{\text { caolinita }}+$ hidrargilita \\
\hline $133 b$ & 20 & Idem, porem horizonte $b$ & " & idem \\
\hline $156 b$ & 21 & $\begin{array}{l}\text { Americana, Faz. Salto } \\
\text { Grande }\end{array}$ & " & caolinita \\
\hline $156 c$ & 22 & Idem, porem horizonte c & ". & $\begin{array}{c}\text { caolinita }+ \text { hidrargilita } \\
\left.\text { (pouca) }+\underset{\text { (muito) }}{+} \mathrm{Fe}_{3} \mathrm{O}_{3} \mathrm{nH}_{2} \mathrm{O}\right) \\
\end{array}$ \\
\hline $165 a$ & 23 & $\begin{array}{l}\text { Mogí-Mirim, estrada a } \\
\text { Conchal }\end{array}$ & " & $\underset{\text { (pouca) }}{\text { caolinita }}+$ hidrargilita \\
\hline $187 \mathrm{c}$ & 24 & $\begin{array}{l}\text { Pilar, estrada a São } \\
\text { Miguel Arcanjo }\end{array}$ & “ & caolinita + hidrargilita \\
\hline $190 a$ & 25 & $\begin{array}{l}\text { Estrada de Gramadinho } \\
\text { a Capão Bonito }\end{array}$ & “ & idem \\
\hline $190 \mathrm{~b}$ & 26 & Idem, porem horizonte b & . & idem \\
\hline $195 a$ & 27 & $\begin{array}{l}\text { Estrada entre Faxina e } \\
\text { Taberá }\end{array}$ & " & $\underset{\text { (pouca) }}{+ \text { hidrargilita }}$ \\
\hline $195 b$ & 28 & Idem, porem horizonte $b$ & " & idem \\
\hline $16 \mathrm{c}$ & 29 & $\begin{array}{l}\text { Estrada de Indaiatuba } \\
\text { a Itú ; horizonte c }\end{array}$ & " & caolinita \\
\hline $157 b$ & 30 & $\begin{array}{l}\text { Americana, próximo a } \\
\text { Saltinho }\end{array}$ & " & $\begin{array}{l}\text { caolinita }+ \text { (hidrargilita } \\
\ominus \mathrm{Fe}_{2} \mathrm{O}_{3} \mathrm{nH}_{2} \mathrm{O} \text { pouco) }\end{array}$ \\
\hline
\end{tabular}



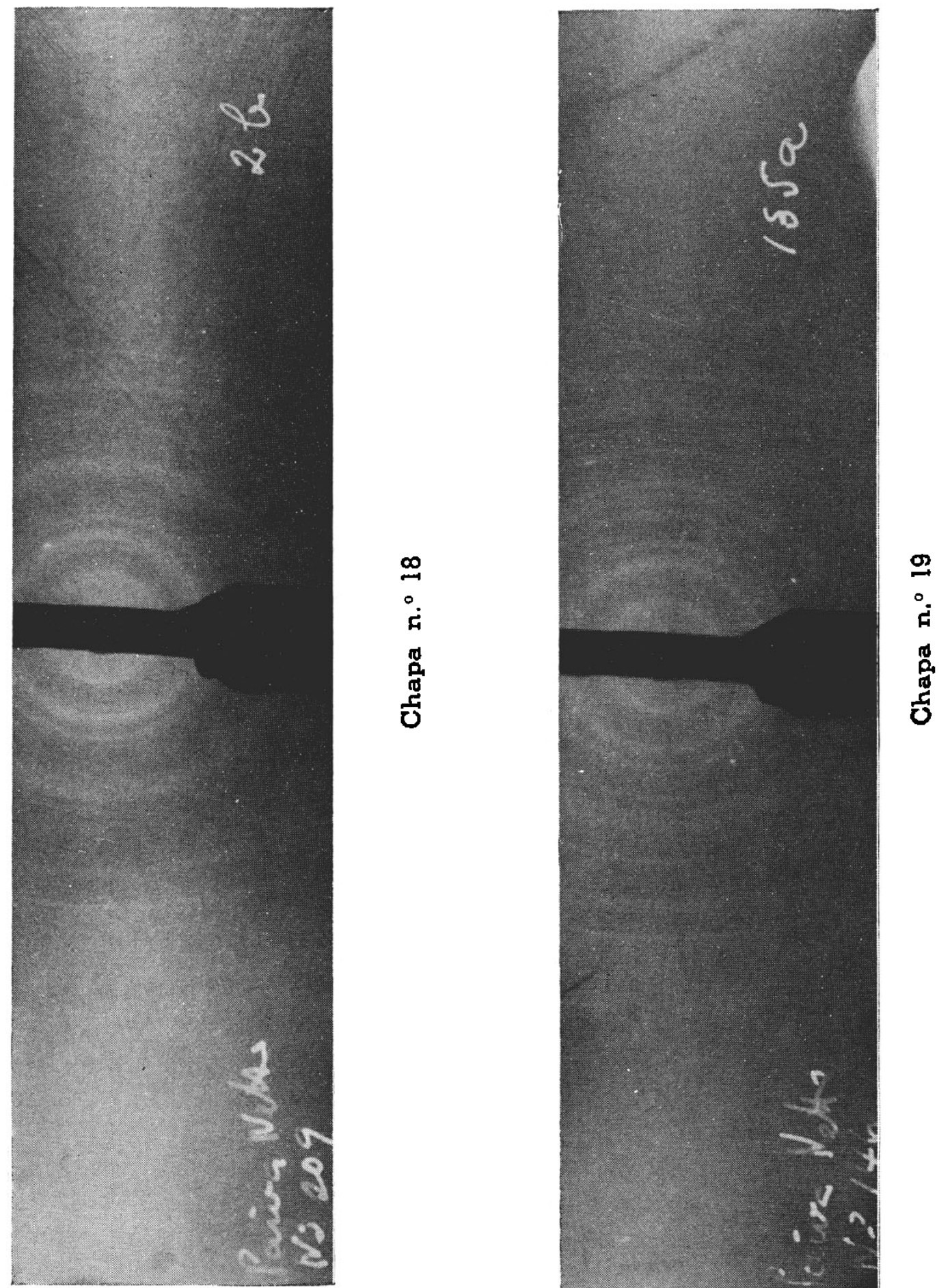

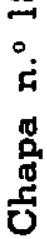

or

تं

葛

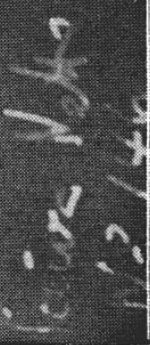



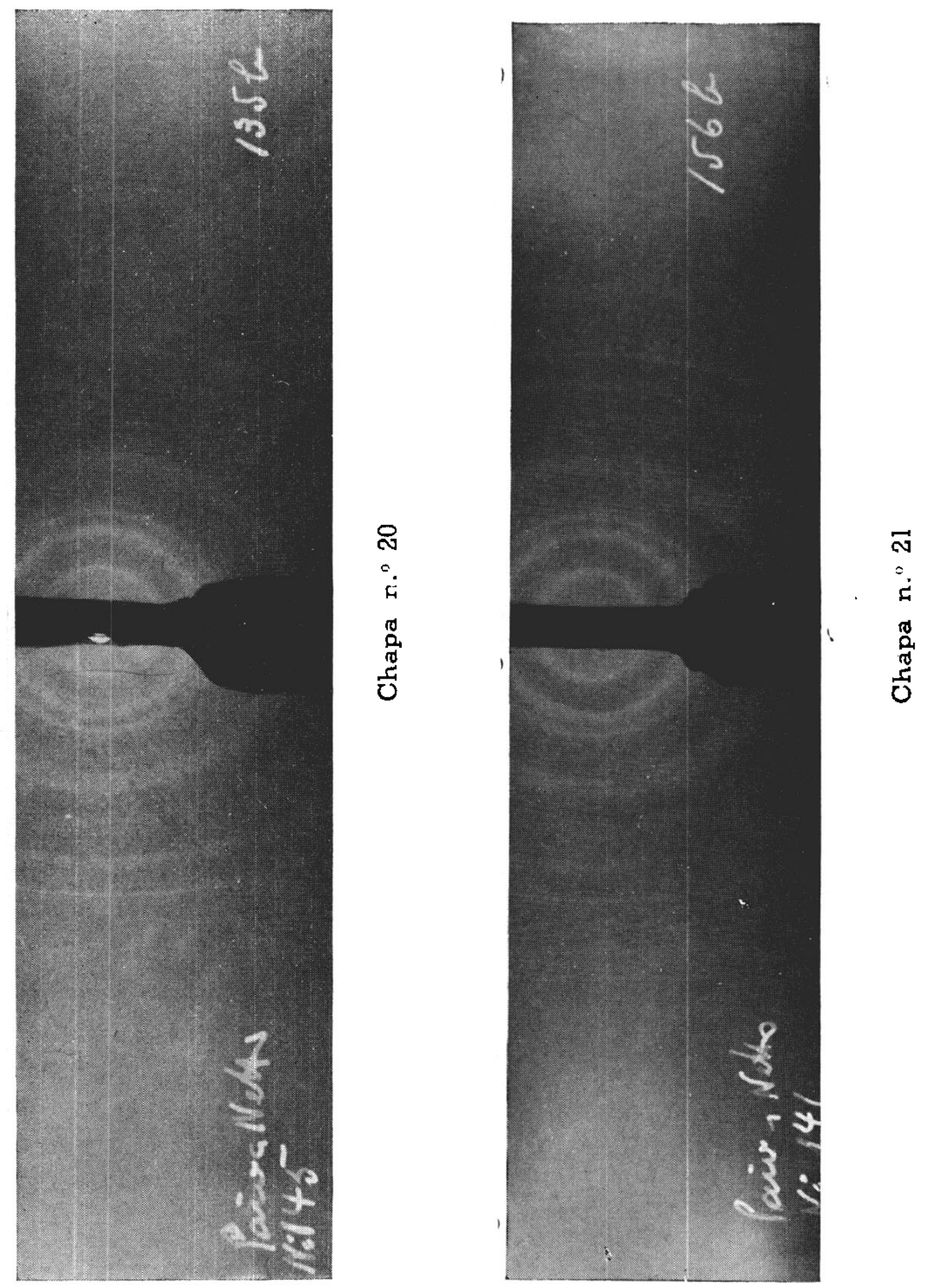

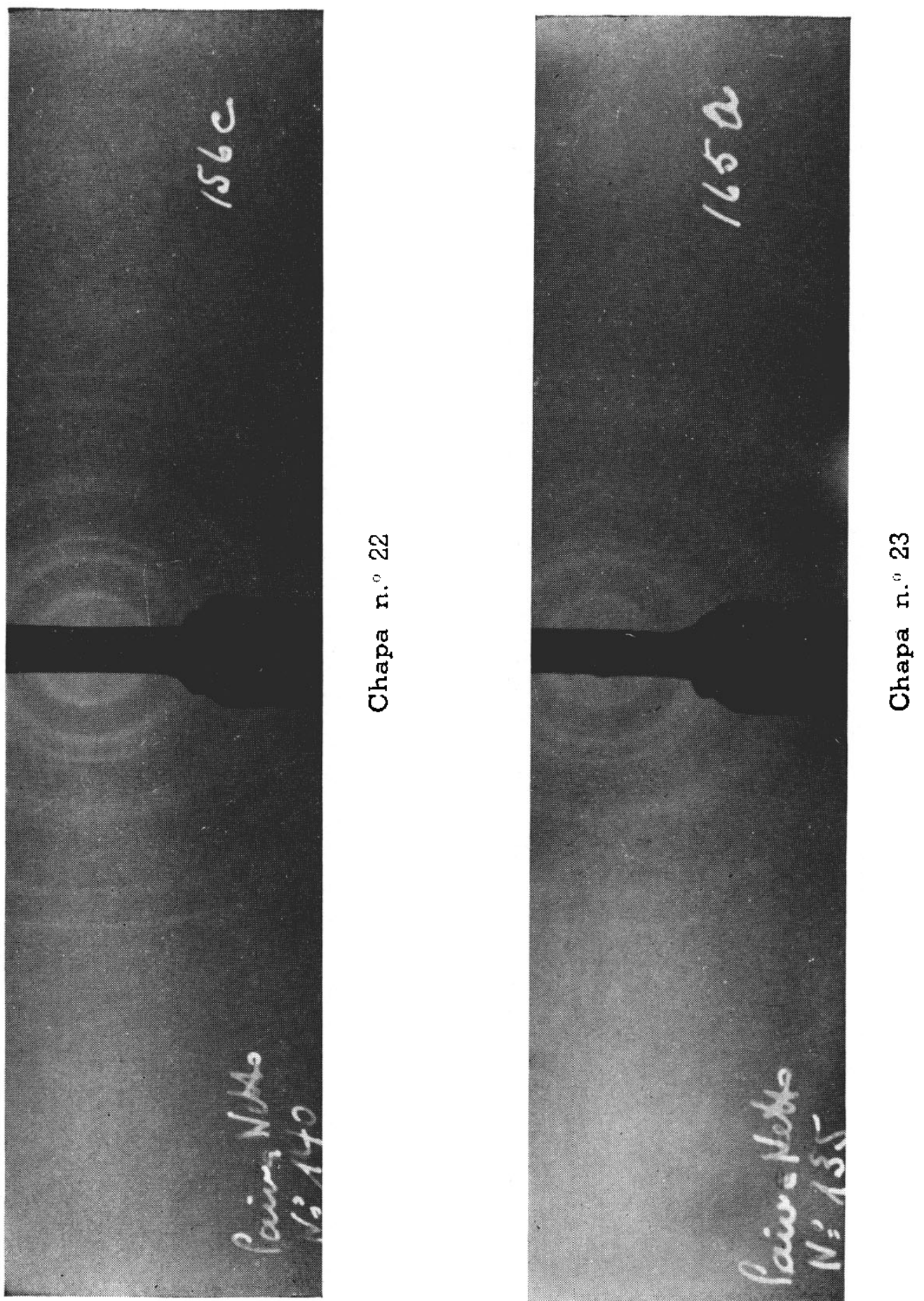

刃
0.
4
0
0
0
0
0
0

 


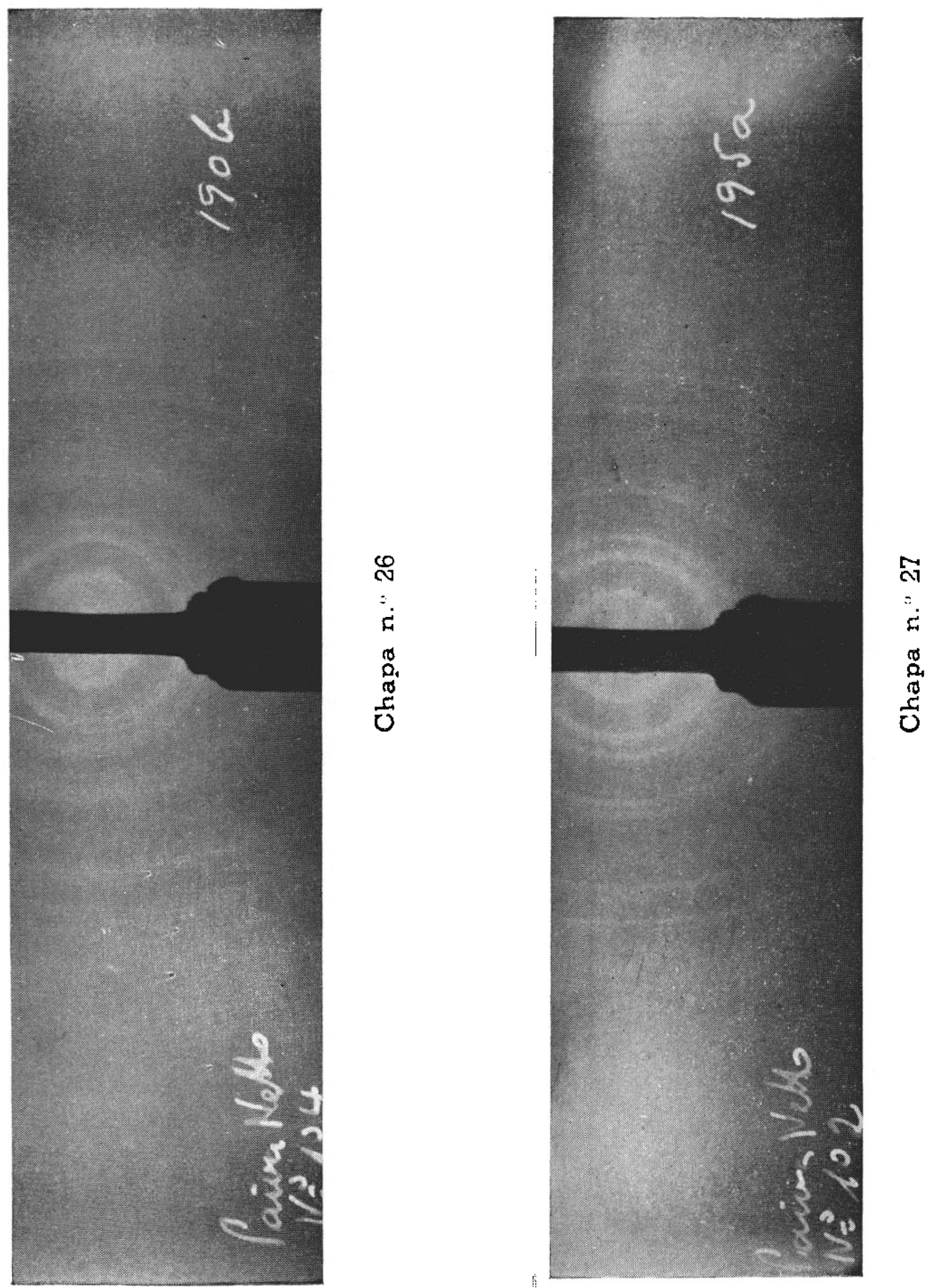

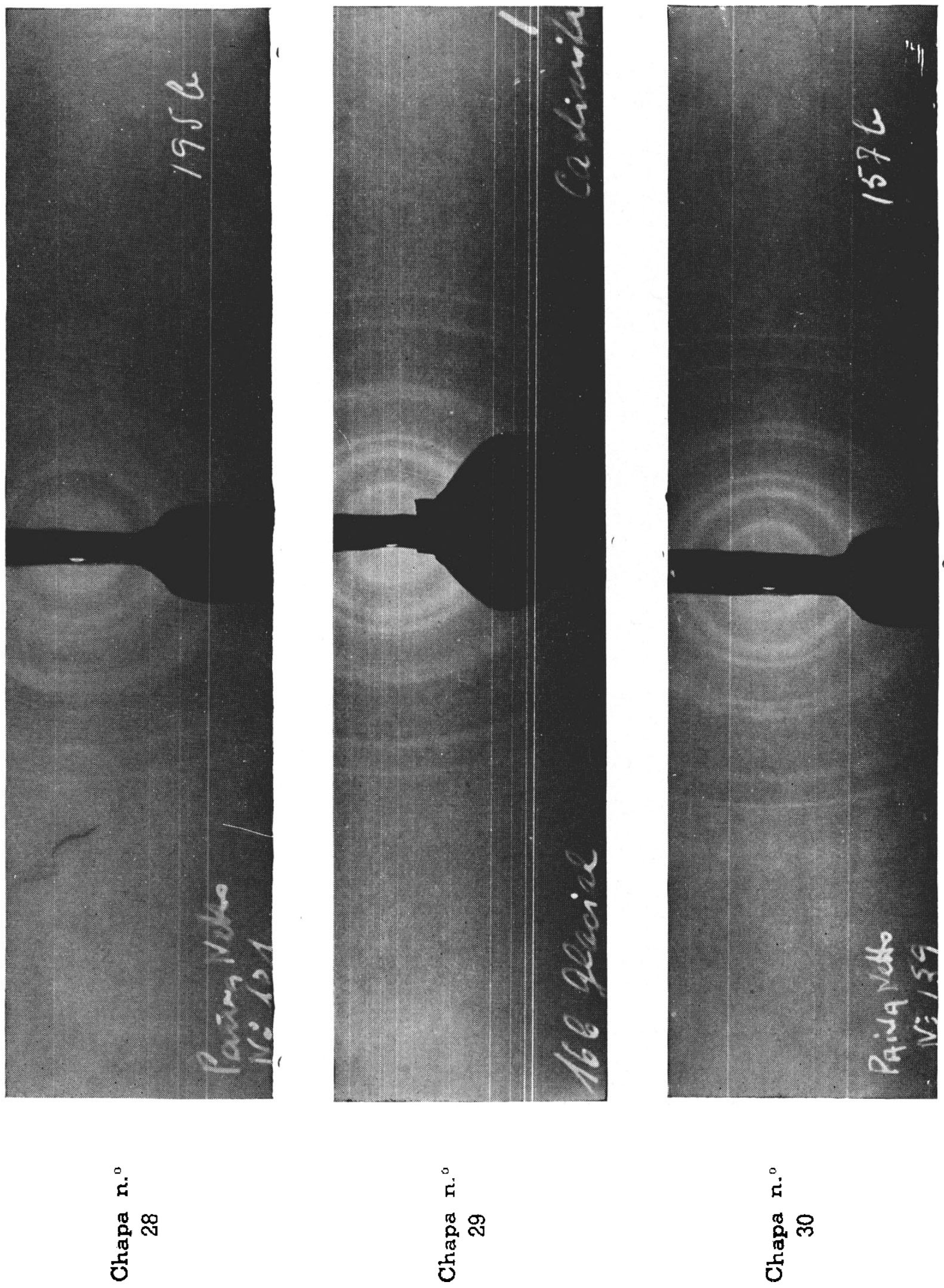

$\stackrel{\circ}{4}$

苋 
Formação geológica

CORUMBATAÍ 
ANÁLISE ROENTGENOGRAFICA DA FRAÇÃO ARGILA DE PERFIS SITUADOS NA FORMAÇÃO GEOLÓGICA C O R U M B A T A I

\begin{tabular}{|c|c|c|c|c|}
\hline $\begin{array}{l}\text { N.o dos } \\
\text { perfís }\end{array}$ & $\begin{array}{l}\text { N.० das } \\
\text { chapas }\end{array}$ & $\begin{array}{c}\text { LOCALIZAÇAO } \\
\text { DOS } \\
\text { PERFIS DE SOLO }\end{array}$ & $\begin{array}{l}\text { TRATAMENTO } \\
\text { RECEBIDO } \\
\text { PELA ARGILA }\end{array}$ & $\begin{array}{c}\text { ANÁLISE } \\
\text { ROENTGENOGRÁFICA } \\
\text { QUALITATIVA }\end{array}$ \\
\hline $23 c$ & 31 & $\begin{array}{l}\text { Estrada entre Angatuba } \\
\text { e Bom Sucesso }\end{array}$ & nenhum & quarzo $<2$ microns \\
\hline $50 a$ & 32 & $\begin{array}{l}\text { Estrada de Rodagem, } \\
\text { próximo a Porto Ferreira }\end{array}$ & idem & idem \\
\hline $50 a$ & 33 & $\begin{array}{l}\text { Idem, porem com trata- } \\
\text { mento }\end{array}$ & $\begin{array}{l}\text { parte ultra fina da } \\
\text { da fração argila } \\
\text { tratada com } \mathrm{HCl} \\
\pm 3 \mathrm{~N}\end{array}$ & idem \\
\hline $59 c$ & 34 & $\begin{array}{l}\text { Itapetininga, Faz. Ara. } \\
\text { ras }\end{array}$ & $\begin{array}{c}\text { tratada com } \mathrm{HCl} \\
\pm 3 \mathrm{~N}\end{array}$ & $\begin{array}{l}\text { quarzo }<2 \text { microns }+ \\
\text { caolinita (pouca) }\end{array}$ \\
\hline $60 \mathrm{~b}$ & 35 & Idem & nenhum & quarzo $<2$ microns \\
\hline
\end{tabular}



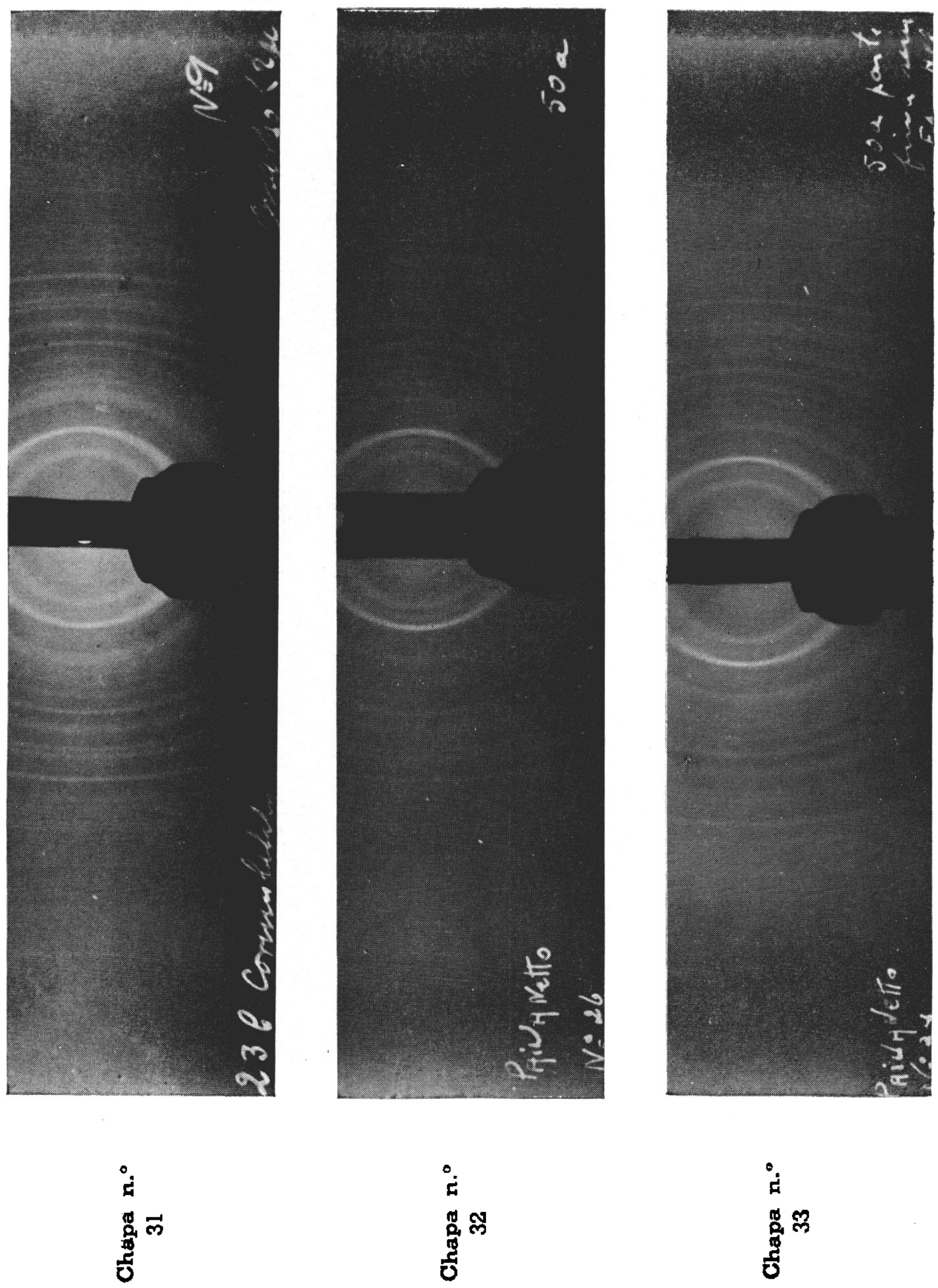

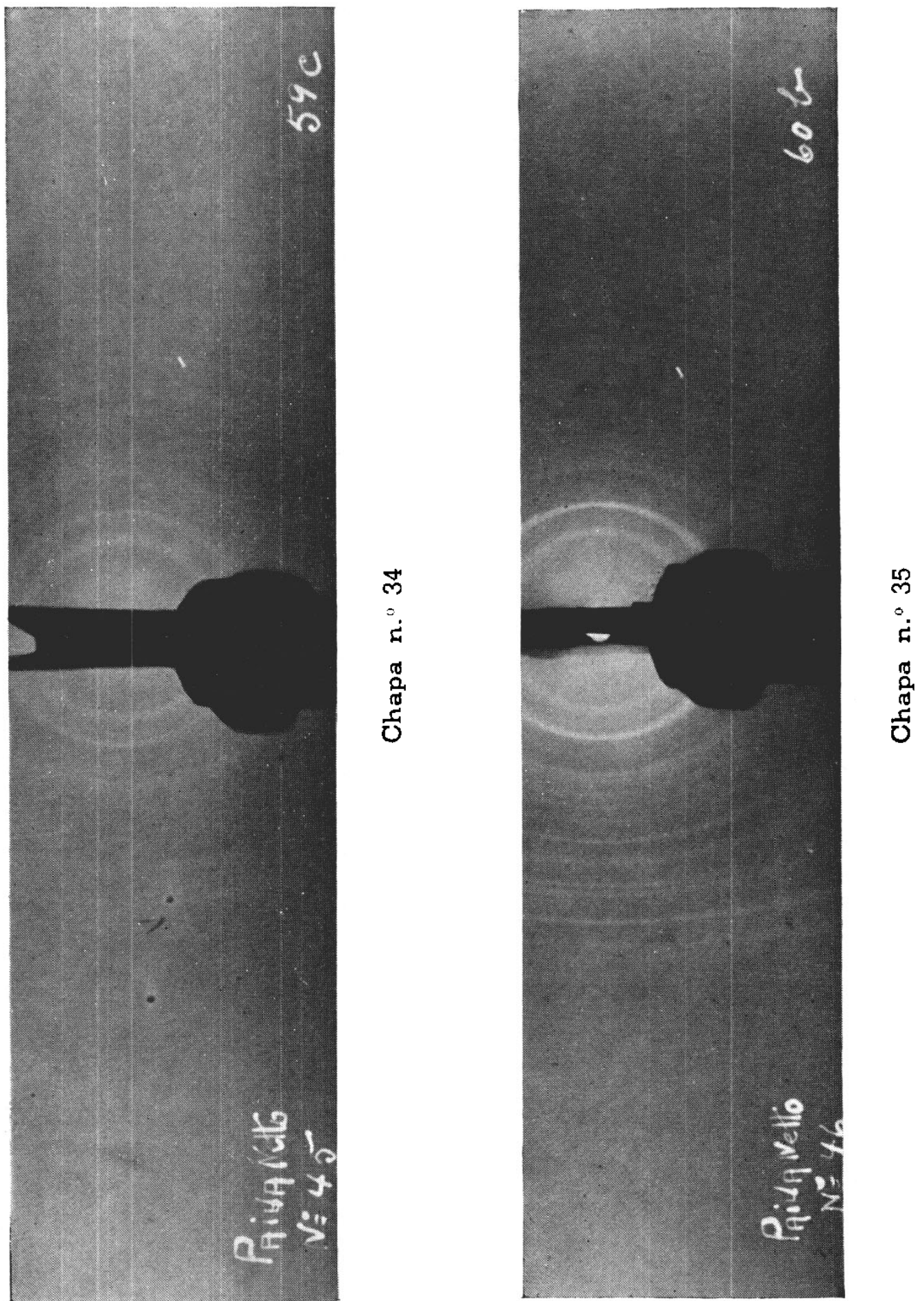

نं

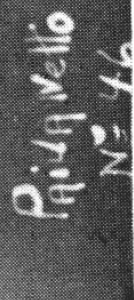




\section{Formação geológica}

\section{BOTUCATÚ (LAVA) (TERRA ROXA LEGITIMA)}


ANÁLISE ROENTGENOGRAFICA DA FRAÇÃO ARGILA DE PERFIS SITUADOS NA FORMAÇÃO GEOLOGICA BOTUCATÚ (LAVA) (TERRA ROXA LEGITIMA)

\begin{tabular}{|c|c|c|c|c|}
\hline $\begin{array}{l}\text { N. } .^{\circ} \text { dos } \\
\text { perfís }\end{array}$ & $\begin{array}{l}\text { N.॰ das } \\
\text { chapas }\end{array}$ & $\begin{array}{c}\text { LOCALIZACAO } \\
\text { DOS } \\
\text { PERFIS DE SOLO }\end{array}$ & $\begin{array}{l}\text { TRATAMENTO } \\
\text { RECEBIDO } \\
\text { PELA ARGILA }\end{array}$ & $\begin{array}{c}\text { ANÁLISE } \\
\text { ROENTGENOGRAFICA } \\
\text { QUALITATIVA }\end{array}$ \\
\hline $49 c$ & 36 & $\begin{array}{l}\text { Faz. Exp. São José } \\
\text { Ribeiräo-Preto }\end{array}$ & nenhum & $\begin{array}{l}\text { caolinita }+ \text { hidrargilita } \\
+ \text { 6xidos hidratados de } \\
\text { ferro }\end{array}$ \\
\hline $49 z$ & 37 & Idem & $\begin{array}{l}\text { tratado com } \mathrm{HCl} \\
\text { concentrado }\end{array}$ & $\begin{array}{l}\text { caolinita }+ \text { hidrargilita } \\
\text { (pouca) }+ \text { oxidos hidra: } \\
\text { tados de ferro }\end{array}$ \\
\hline $213 c$ & 38 & $\begin{array}{l}\text { Estrada entre Ipaussú e } \\
\text { Chavantes }\end{array}$ & nenhum & $\begin{array}{l}\text { caolinita + óxidos hidra- } \\
\text { tados de ferro }\end{array}$ \\
\hline $49 a$ & 39 & $\begin{array}{l}\text { Faz. Exp. São José } \\
\text { Ribeirão-Preto }\end{array}$ & $\begin{array}{l}\text { tratado com } \mathrm{HCl} \\
\text { concentrado }\end{array}$ & $\begin{array}{l}\text { caolinita }+ \text { hidrargilita } \\
\text { (pouca) }+ \text { oxidos hidra- } \\
\text { tados de ferro }\end{array}$ \\
\hline $49 b$ & 40 & Idem, porem horizonte $b$ & Idem & $\begin{array}{l}\text { composição idêntica d̀ } \\
\text { precedente }\end{array}$ \\
\hline $49 c$ & 41 & Idem, porem horizonte c & nenhum & $\begin{array}{l}\text { caolinita }+ \text { hidrargilita }+ \\
\text { óxidos hidratados de ferro }\end{array}$ \\
\hline
\end{tabular}



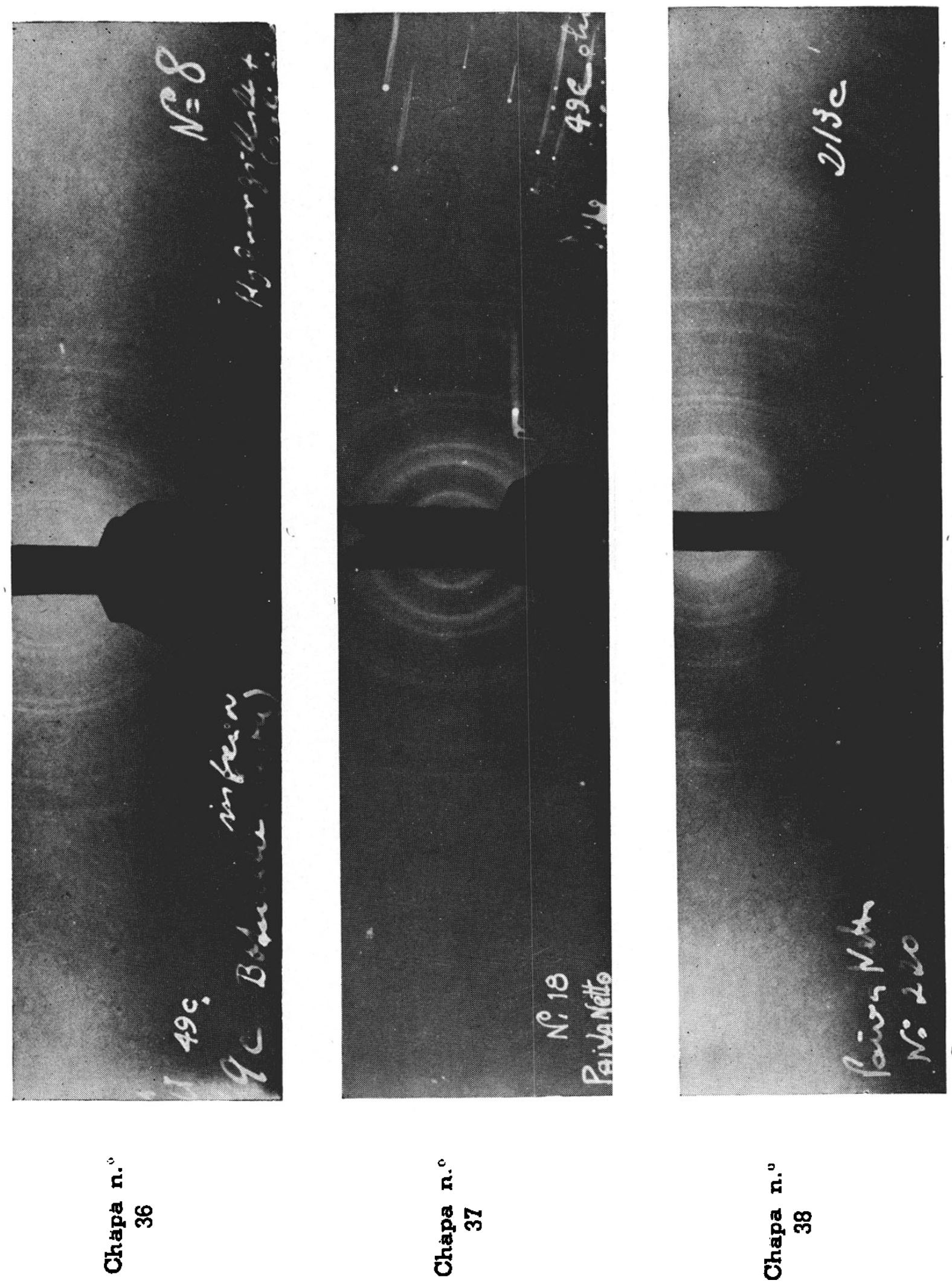

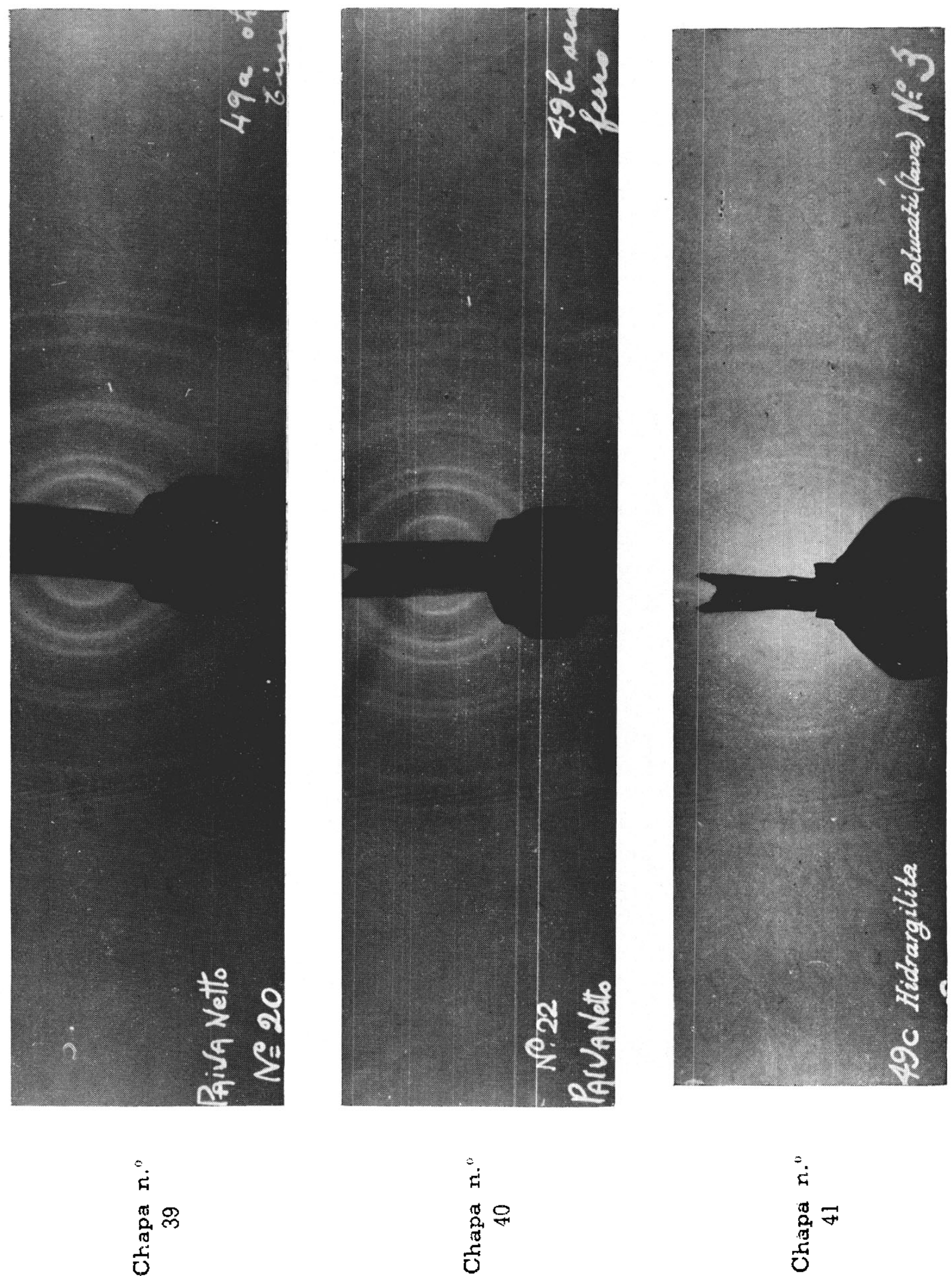
Formação geológica

CAIUÁ? BAURÚ INFERIOR? 
ANÁLISE ROENTGENOGRÁFICA DA FRAÇ̃̃O ARGILA DE PERFÍS SITUADOS NA FORMAÇÃO GEOLÓGICA CAIUÁ ? BAURÚ INFERIOR ?

\begin{tabular}{|c|c|c|c|c|}
\hline $\begin{array}{l}\text { N. }{ }^{\circ} \text { dos } \\
\text { perfís }\end{array}$ & $\begin{array}{l}\text { N.० das } \\
\text { chapas }\end{array}$ & $\begin{array}{l}\text { LOCALIZAÇAO } \\
\text { DOS } \\
\text { PERFÍS DE SOLO }\end{array}$ & $\begin{array}{l}\text { TRATAMENTO } \\
\text { RECEBIDO } \\
\text { PELA ARGILA }\end{array}$ & $\begin{array}{c}\text { ANALISE } \\
\text { ROENTGENOGRÁFICA } \\
\text { QUALITATIVA }\end{array}$ \\
\hline $43 \mathrm{~b}$ & 42 & $\begin{array}{l}\text { Estrada entre Arara- } \\
\text { quara e Matão }\end{array}$ & nenhum & caolinita + hidrargilita \\
\hline $43 c$ & 43 & Idem, porem horizonte c & Idem & Idem \\
\hline $72 \mathrm{a}$ & 44 & $\begin{array}{l}\text { Entre Araraquara e } \\
\text { Nova Paulicéia }\end{array}$ & . & $\underset{\text { (pouquíssima) }}{\text { caolinita }+ \text { hidrargilita }}$ \\
\hline $72 b$ & 45 & Idem, porem horizonte b & " & idem \\
\hline $80 a$ & 46 & $\begin{array}{l}\text { Estrada entre Brodo- } \\
\text { wsky e Batatais }\end{array}$ & " & $\underset{\text { (pouquíssima) }}{\text { hidrargilita }+ \text { caolinita }}$ \\
\hline $80 b$ & 47 & Idem, porem horizonte $b$ & " & idem \\
\hline $83 a$ & 48 & $\begin{array}{l}\text { Estrada entre Pedre- } \\
\text { gulho e Cristais }\end{array}$ & ", & $\ldots$ \\
\hline $83 b$ & 49 & Idem, porem horizonte b & " & 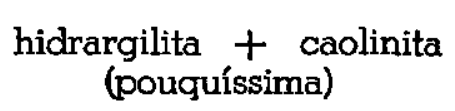 \\
\hline $101 a$ & 50 & $\begin{array}{l}\text { Estrada entre Araça- } \\
\text { tuba e Iporanga }\end{array}$ & " & $\underset{\text { (pouca) }}{\text { caolinita }}+$ hidrargilita \\
\hline $101 b$ & 51 & Idem, porem horizonte b & " & idem \\
\hline $108 a$ & 52 & $\begin{array}{l}\text { Arapuá, E. M. Grosso, } \\
\text { próximo à divisa com } \\
\text { São Paulo }\end{array}$ & " & " \\
\hline $108 b$ & 53 & Idem, porem horizonte b & ". & ", \\
\hline $111 a$ & 54 & $\begin{array}{l}\text { Mandaguarí, próximo a } \\
\text { Presidente Prudente }\end{array}$ & ", & " \\
\hline $111 b$ & 55 & Idem, porem horizonte $b$ & ", & " \\
\hline $27 \mathrm{c}$ & 56 & Entre Avaré e Itatinga & " & caolinita + hidrargilita \\
\hline
\end{tabular}

Estas amostras, geologicamente, estão classificadas como sendo CAIUÁ (Baurú inferior); isto, entretanto. devemos tomar com certa reserva. 

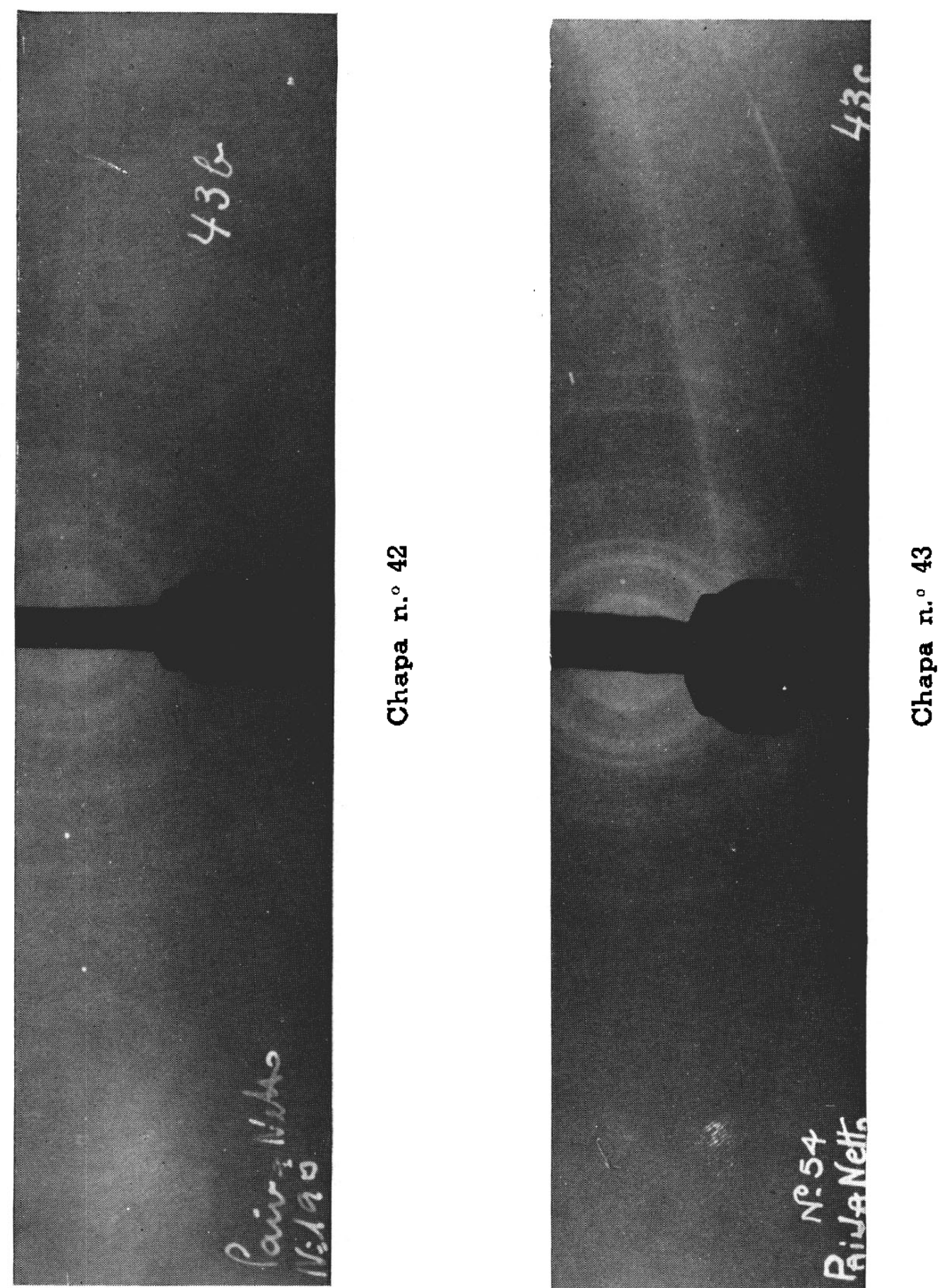
Vol. 2
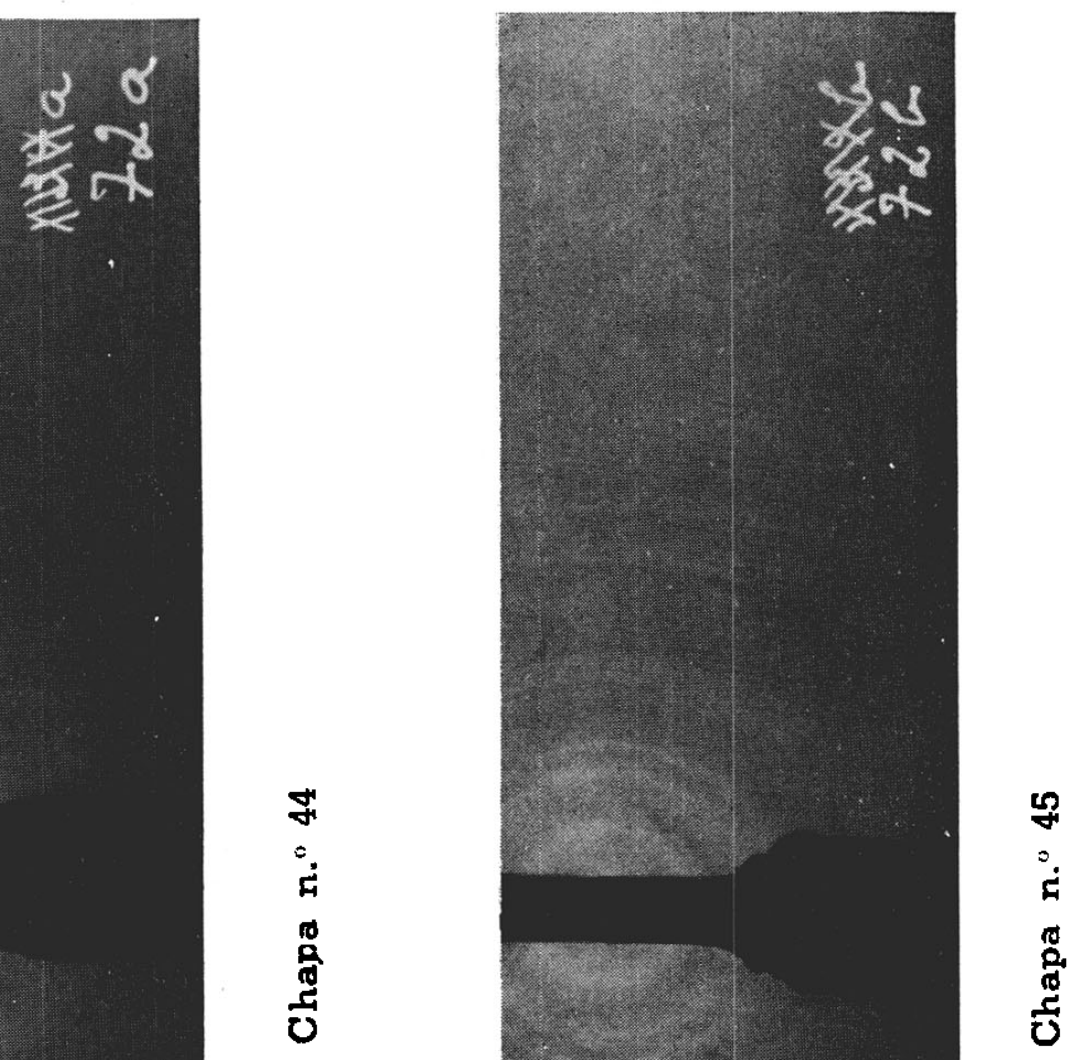

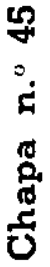
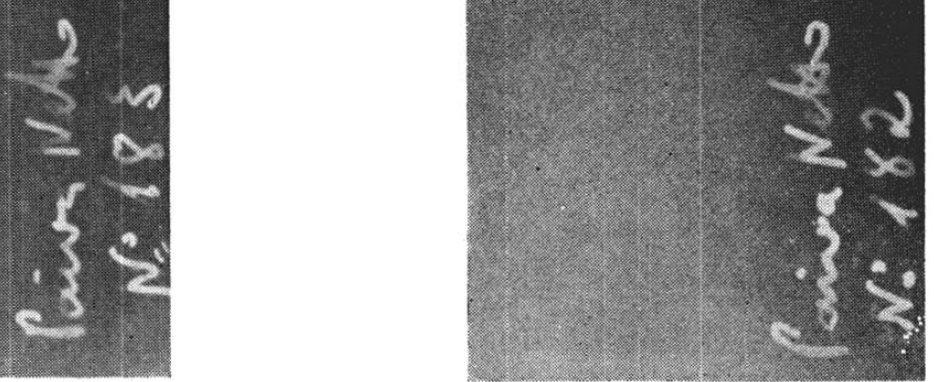

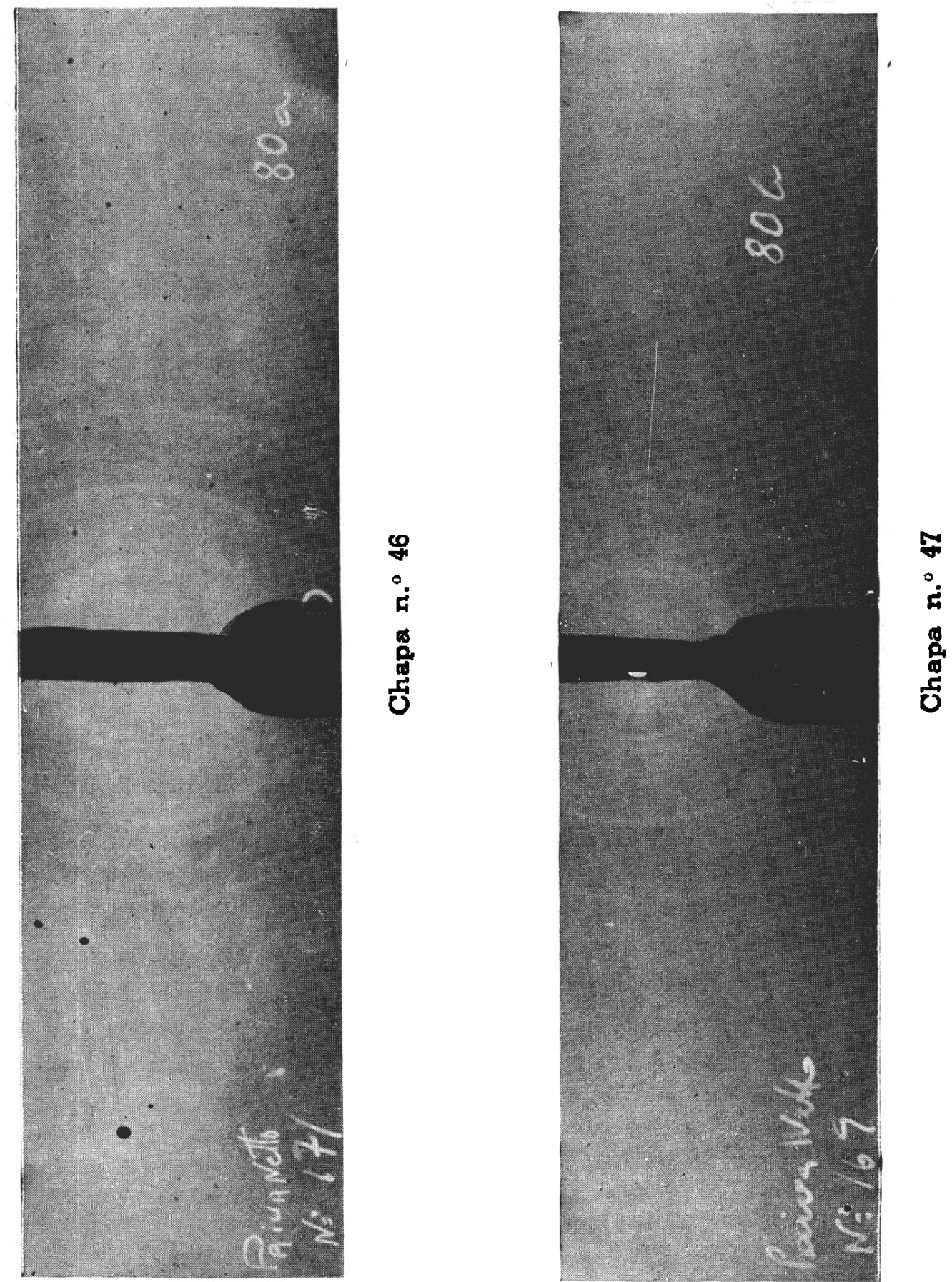

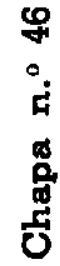

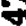

葛 

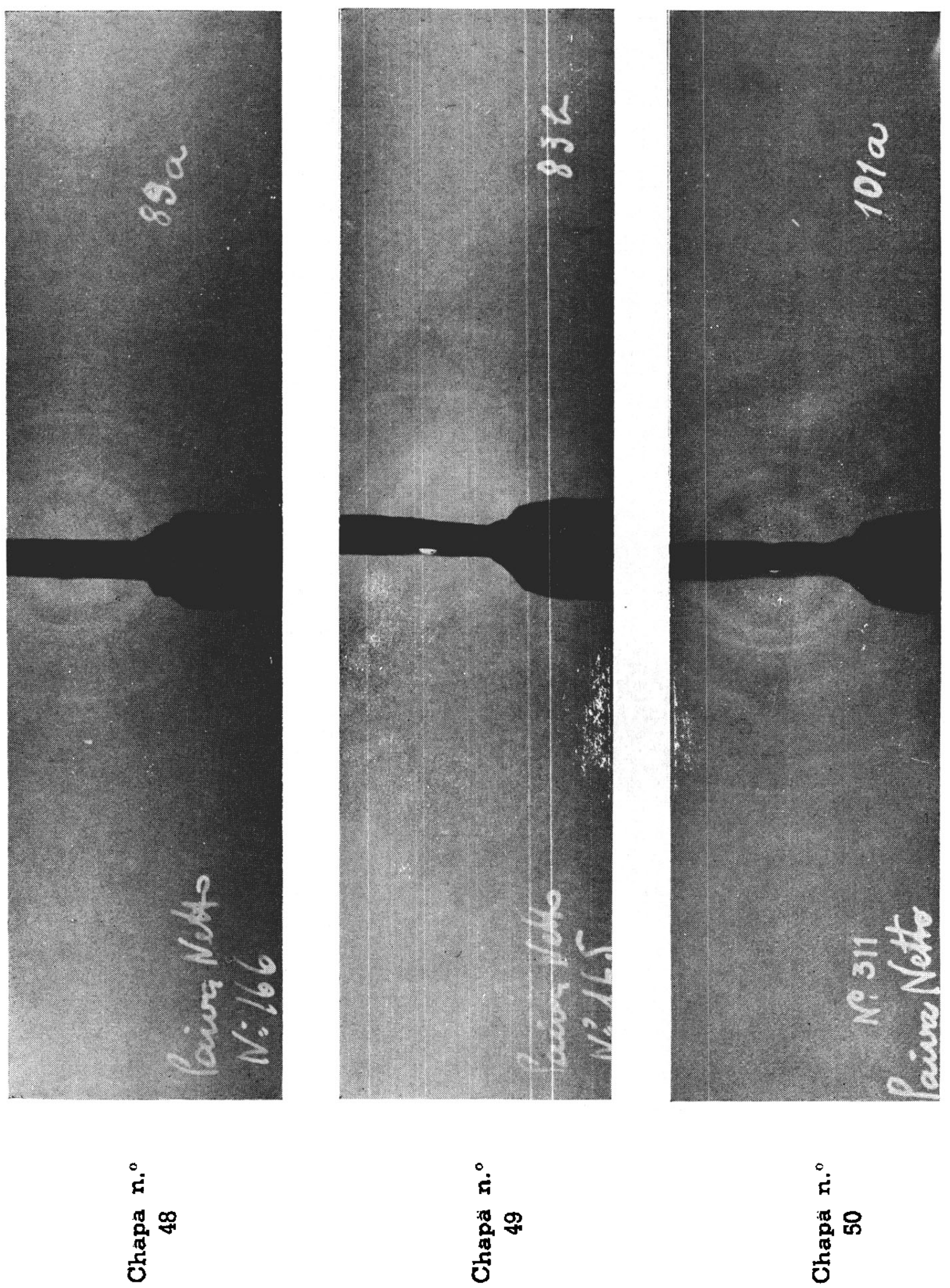

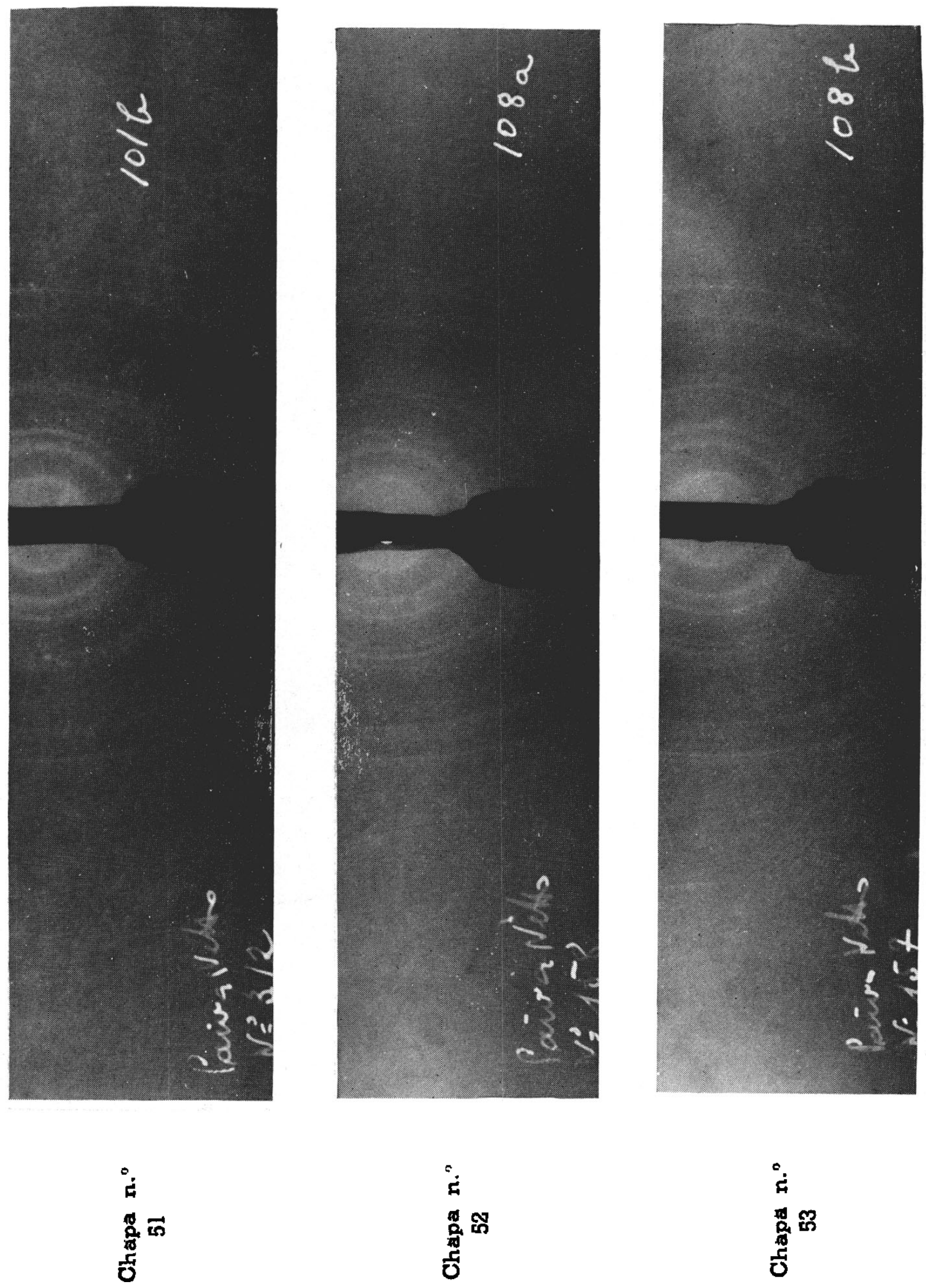

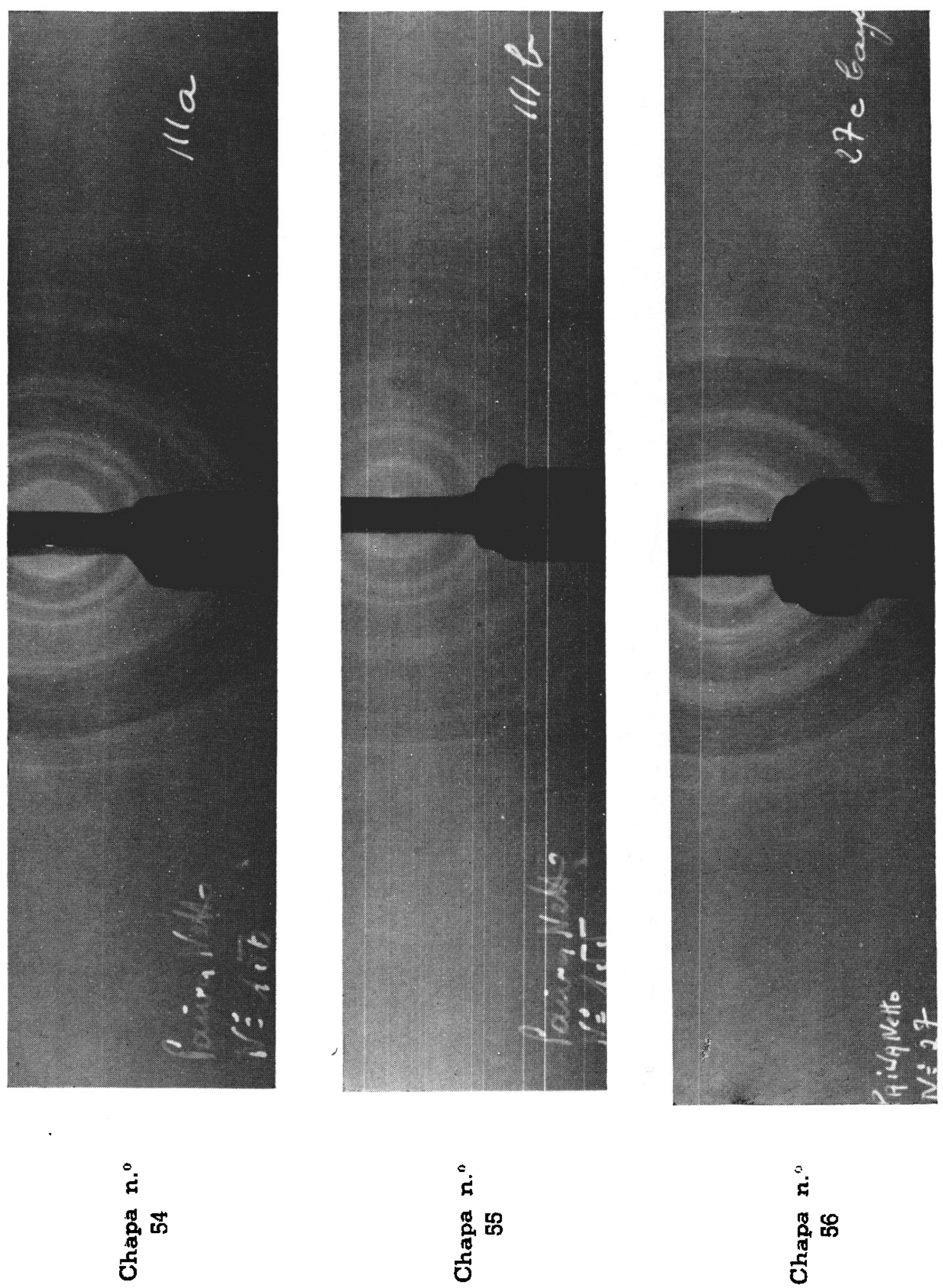


\section{Formação geológica BAURÚ (SUPERIOR)}




\section{ANÁLISE ROENTGENOGRÁFICA DA FRAÇÃO ARGILA DE PERFIS SITUADOS NA FORMAÇÃO GEOLÓGICA BAURÚ (SUPERIOR)}

\begin{tabular}{|c|c|c|c|c|}
\hline $\begin{array}{l}\text { N. }{ }^{\circ} \text { dos } \\
\text { perfís }\end{array}$ & $\begin{array}{l}\text { N. }{ }^{\circ} \text { das } \\
\text { chapas }\end{array}$ & $\begin{array}{l}\text { LOCALIZAÇAO } \\
\text { DOS } \\
\text { PERFIS DE SOLO }\end{array}$ & $\begin{array}{l}\text { TRATAMENTO } \\
\text { RECEBIDO } \\
\text { PELA ARGILA }\end{array}$ & $\begin{array}{c}\text { ANÁLISE } \\
\text { ROENTGENOGRÁFICA } \\
\text { QUALITATIVA }\end{array}$ \\
\hline $27 b$ & 57 & $\begin{array}{l}\text { Estrada entre Agudos } \\
\text { e Baurú }\end{array}$ & nenhum & caolinita \\
\hline $37 a$ & 58 & $\begin{array}{l}\text { Entre Nova Granada e } \\
\text { Água Doce }\end{array}$ & $"$ & idem \\
\hline $37 c$ & : 59 & Idem, porem horizonte $c$ & " & " \\
\hline $39 a$ & 60 & $\begin{array}{l}\text { Pindorama, próximo à } \\
\text { Estação Experimental } \\
\text { do I. A. }\end{array}$ & " & $\begin{array}{c}\text { caolinita }+\mathrm{SiO}_{2} \text { (quarzo) } \\
\text { pouquíssimo }\end{array}$ \\
\hline $40 \mathrm{~b}$ & 61 & Próximo ao anterior & $"$ & idem \\
\hline $41 \mathrm{a}$ & 62 & Próximo ao anterior & " & " \\
\hline $41 \mathrm{~b}$ & 63 & Idem, porem horizonte b & " & " \\
\hline $42 c$ & 64 & $\begin{array}{l}\text { Entre Taquaritinga e } \\
\text { Matão }\end{array}$ & " & " \\
\hline $77 a$ & 65 & Monte Alto & „ & argila montmorrilonítica \\
\hline $77 b$ & 66 & Idem, porem horizonte b & $"$ & idem \\
\hline $89 a$ & 67 & Entre Itambé e Olímpia & $"$ & $\begin{array}{c}\text { caolinita }+\mathrm{SiO}_{2} \text { (quarzo) } \\
\text { pouquússimo }\end{array}$ \\
\hline $121 a$ & 68 & Marília & ", & $\begin{array}{l}\text { caolinita }+\mathrm{SiO}_{2} \text { (quarzo) } \\
+ \text { argila montmorriloní- } \\
\text { tica (pouquíssima) }\end{array}$ \\
\hline $121 b$ & 69 & Marília & $"$ & $\begin{array}{c}\text { caolinita }+ \text { montmorrilo- } \\
\text { nita }+\mathrm{SiO}_{2} \text { (quarzo) } \\
\text { pouquíssimo }\end{array}$ \\
\hline $125 b$ & 70 & Entre Baurú e Guaianás & " & $\begin{array}{c}\text { caolinita }+\mathrm{SiO}_{2} \text { (quarzo) } \\
\text { (pouquíssimo) }\end{array}$ \\
\hline $145 a$ & 71 & $\begin{array}{l}\text { Baurú - Faz. Val de } \\
\text { Palmas }\end{array}$ & .. & caolinita \\
\hline $145 b$ & 72 & Idem, horizonte b & " & idem \\
\hline $219 b$ & 73 & $\begin{array}{l}\text { Próximo a Quatá em } \\
\text { direção a Rancharia }\end{array}$ & " & $\begin{array}{c}\text { caolinita }+\mathrm{SiO}_{2} \text { (quarzo) } \\
\text { pouquíssimo }\end{array}$ \\
\hline 77c & 74 & Monte Alto & ", & argila montmorrilonítica \\
\hline $102 a$ & 75 & $\begin{array}{l}\text { Próximo a Araçatuba, } \\
\text { em direção a Frutal }\end{array}$ & "s & caolinita \\
\hline $124 a$ & 76 & Pirajuf--Usina Miranda & idem & $\begin{array}{l}\text { caolinita }+ \text { argila X ou } \\
\text { ilita }\end{array}$ \\
\hline $38 b$ & 77 & $\begin{array}{l}\text { Pindorama - Est. Exp. } \\
\text { do I. A. }\end{array}$ & idem & caolinita \\
\hline $77 \mathrm{a}$ & 78 & Monte Alto & tratado com $\mathrm{HCl}$ & argila montmorrilonítica \\
\hline $77 \mathrm{~b}$ & 79 & Monte Alto & idem & idem \\
\hline
\end{tabular}



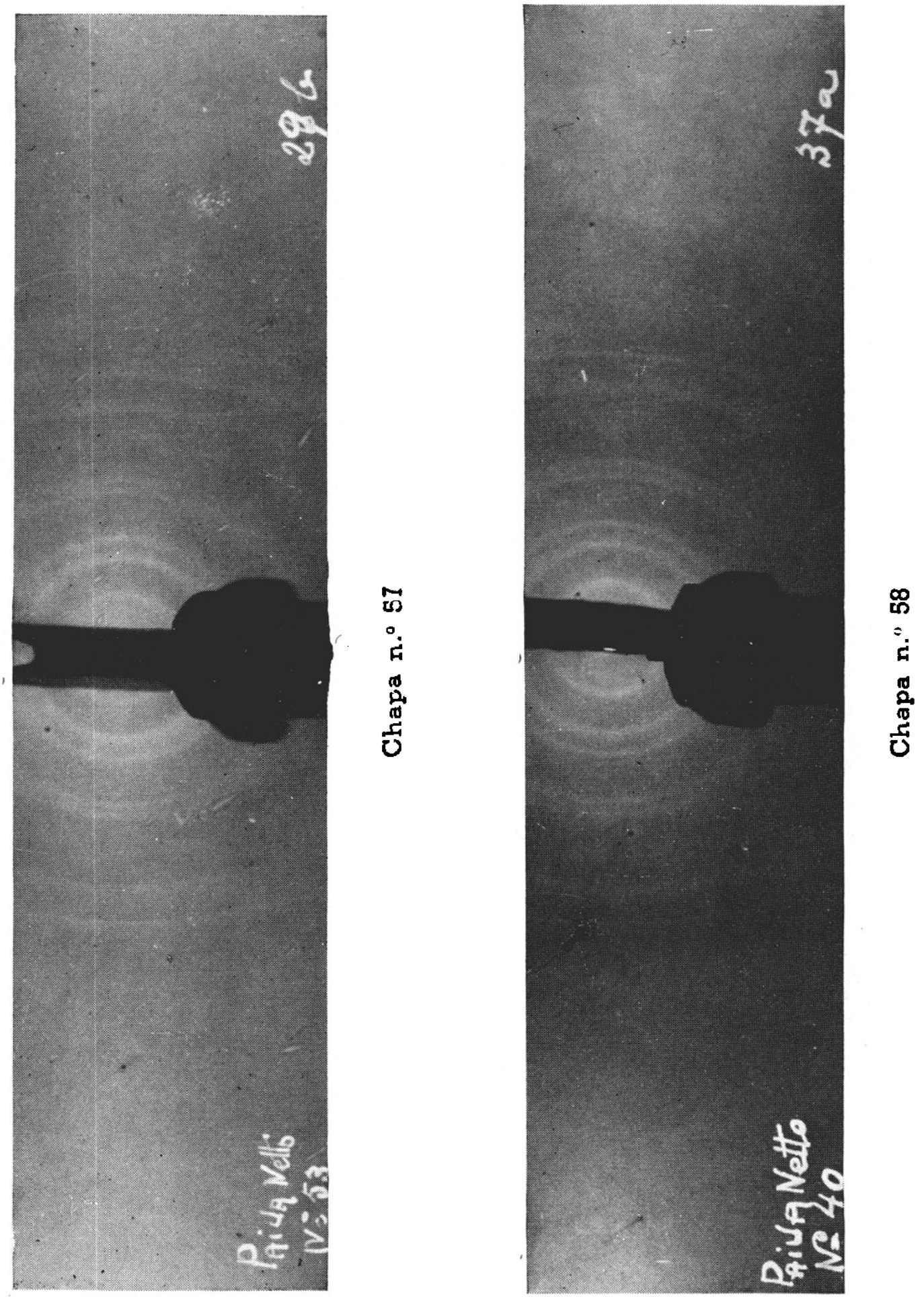

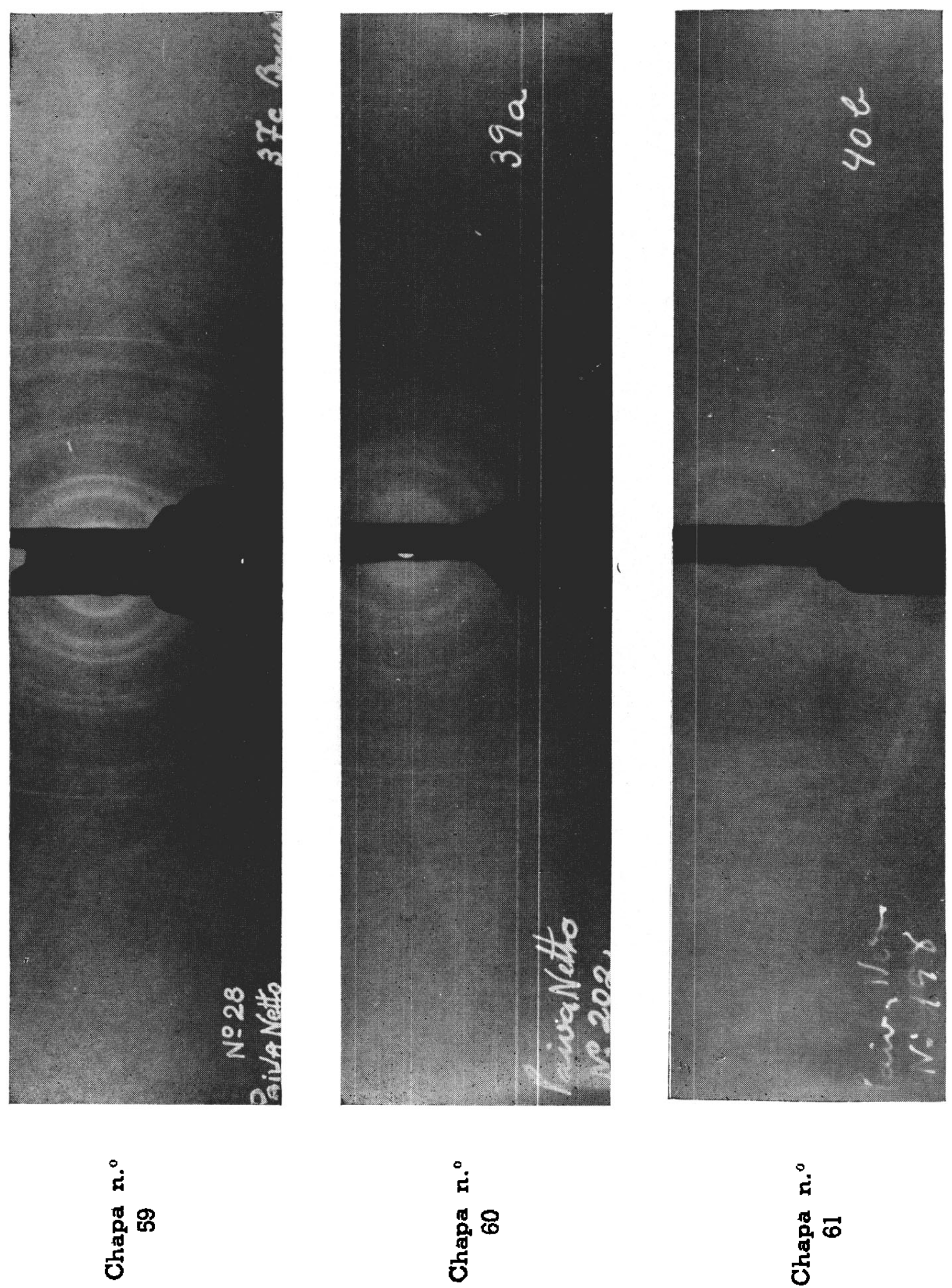

$\stackrel{\circ}{\not}$

웅

䞤 

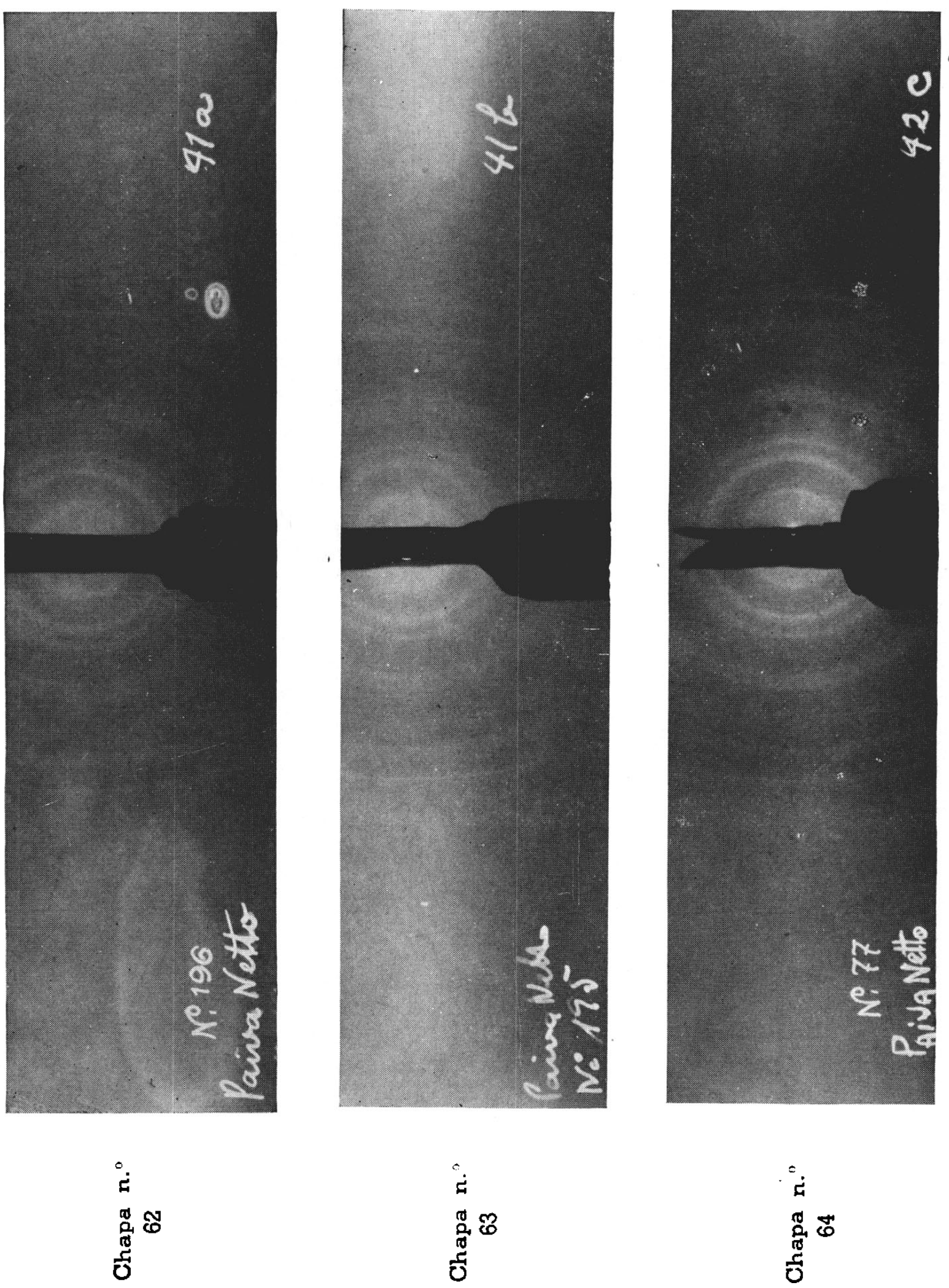

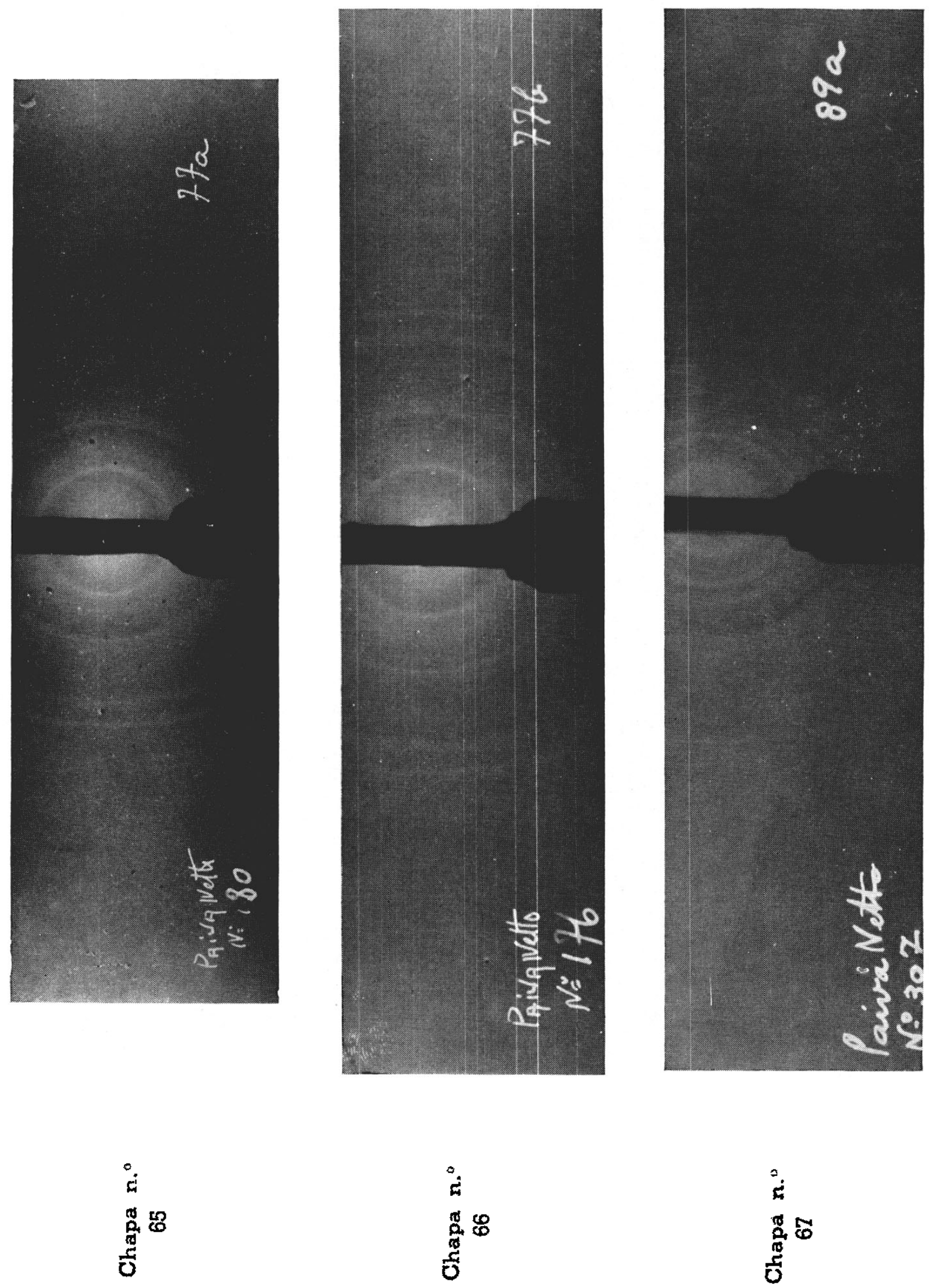

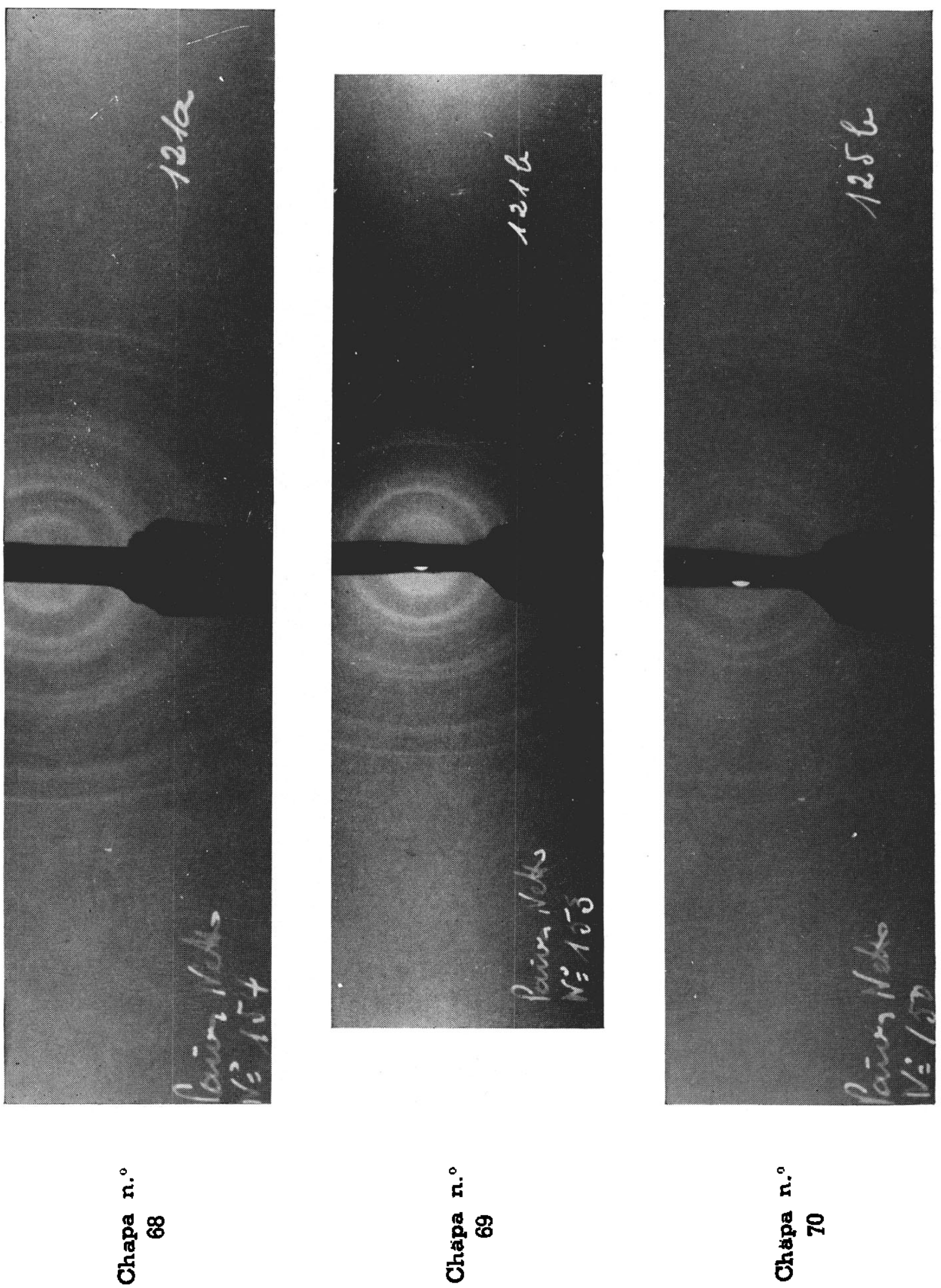

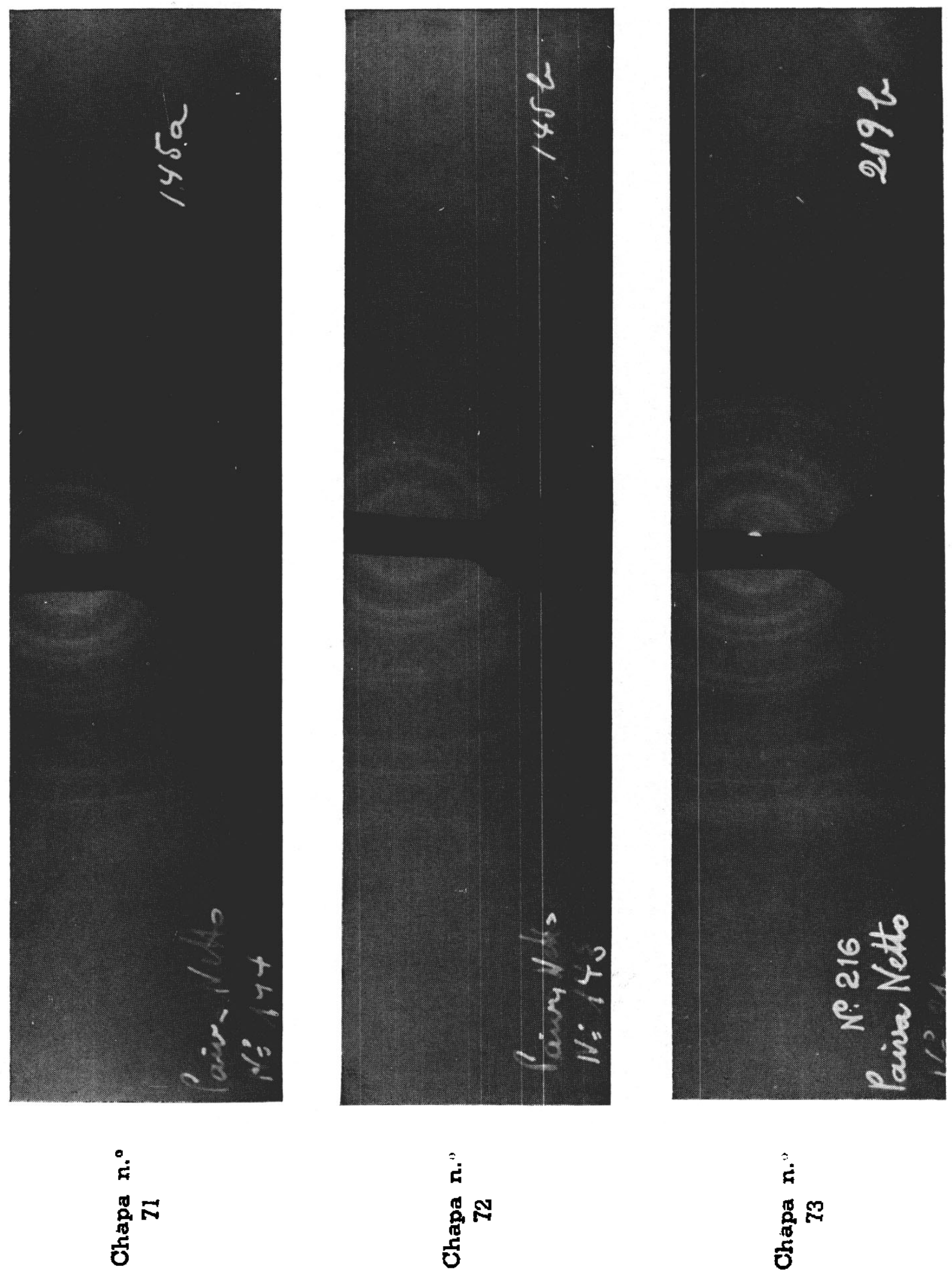

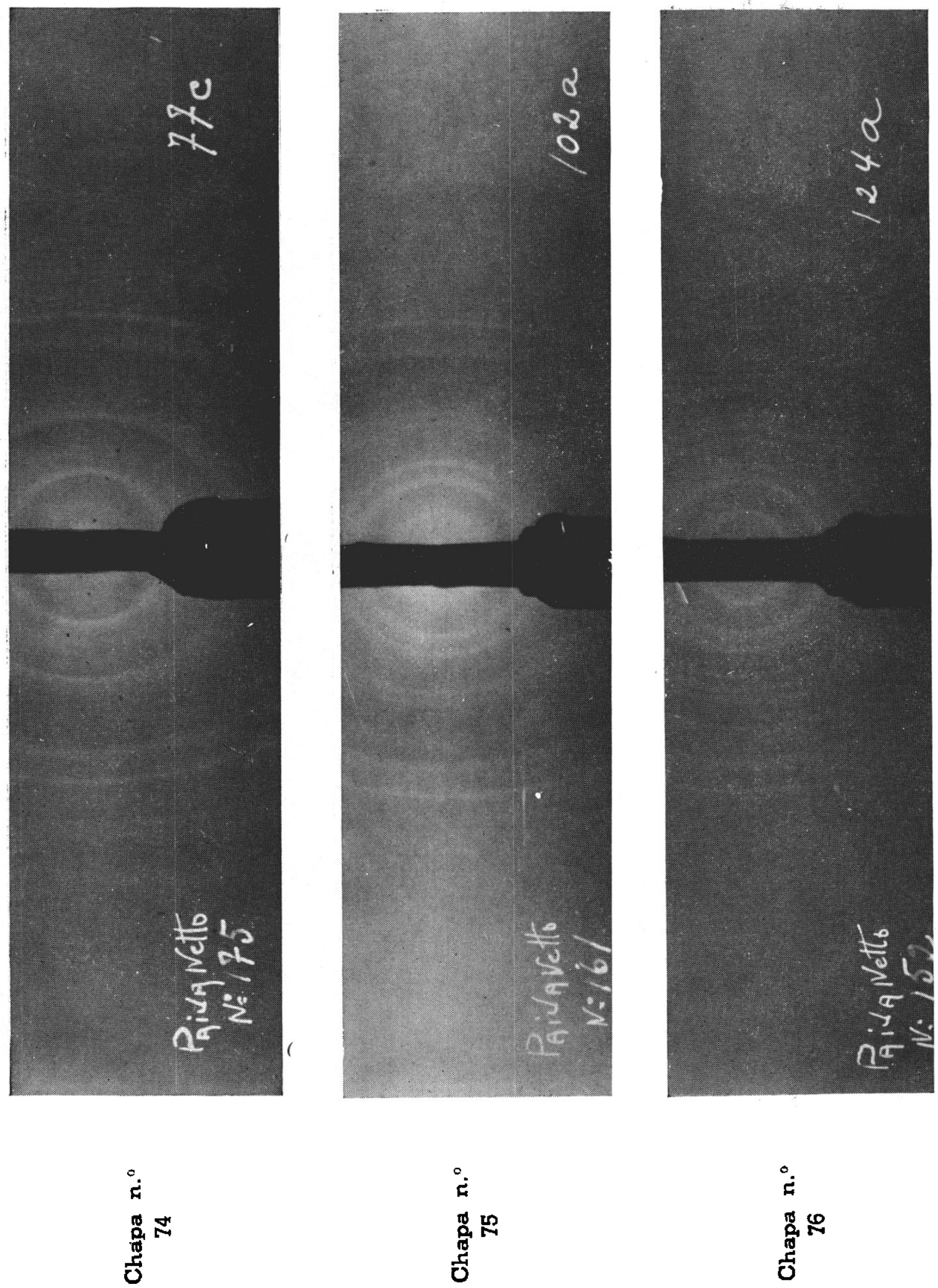

¿

苋品

造
¿.

望 

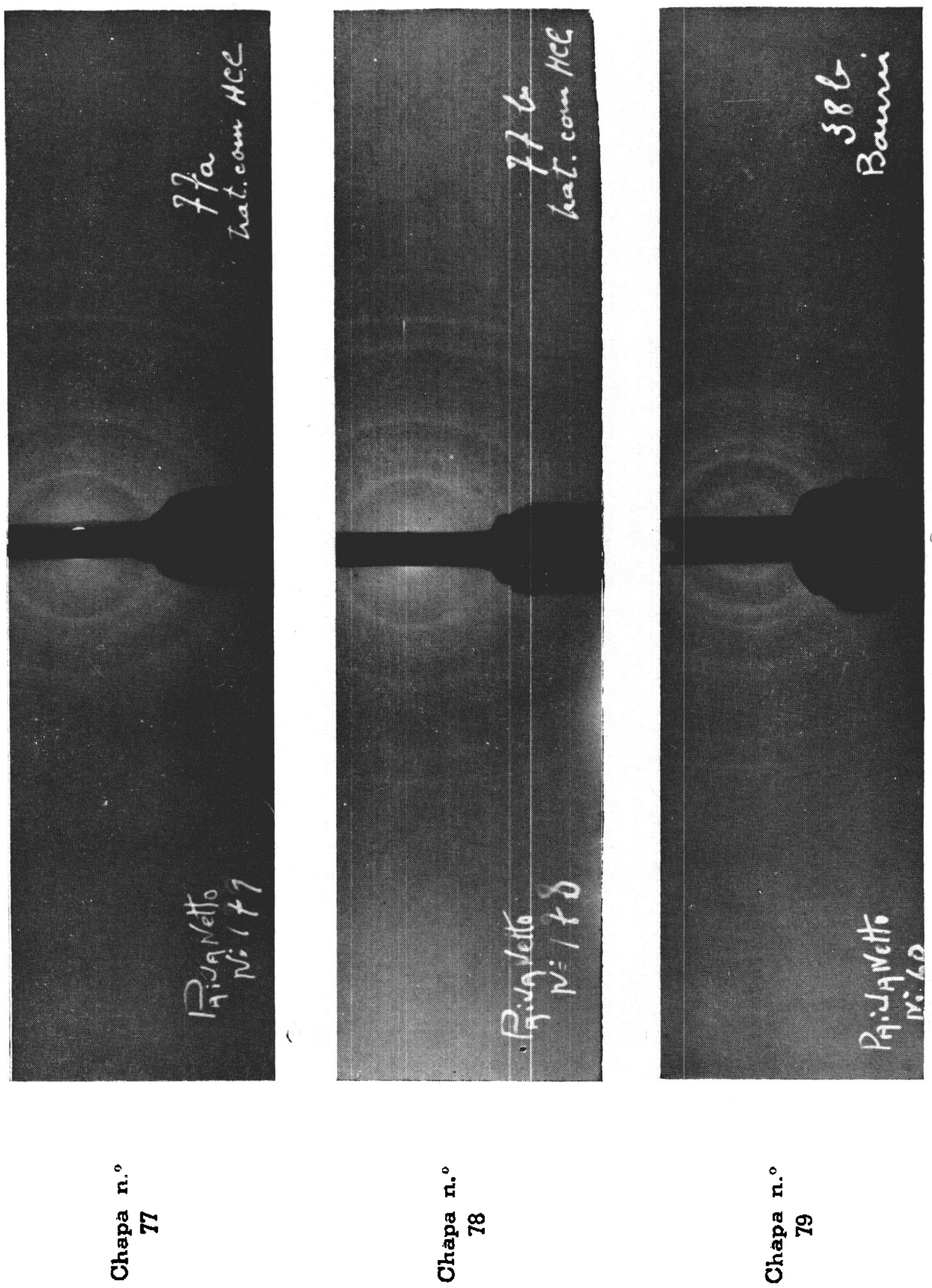